\title{
Evaluating the long-term ecological responses to riparian ecosystem restoration at the Fort Benning, Georgia Military Installation
}

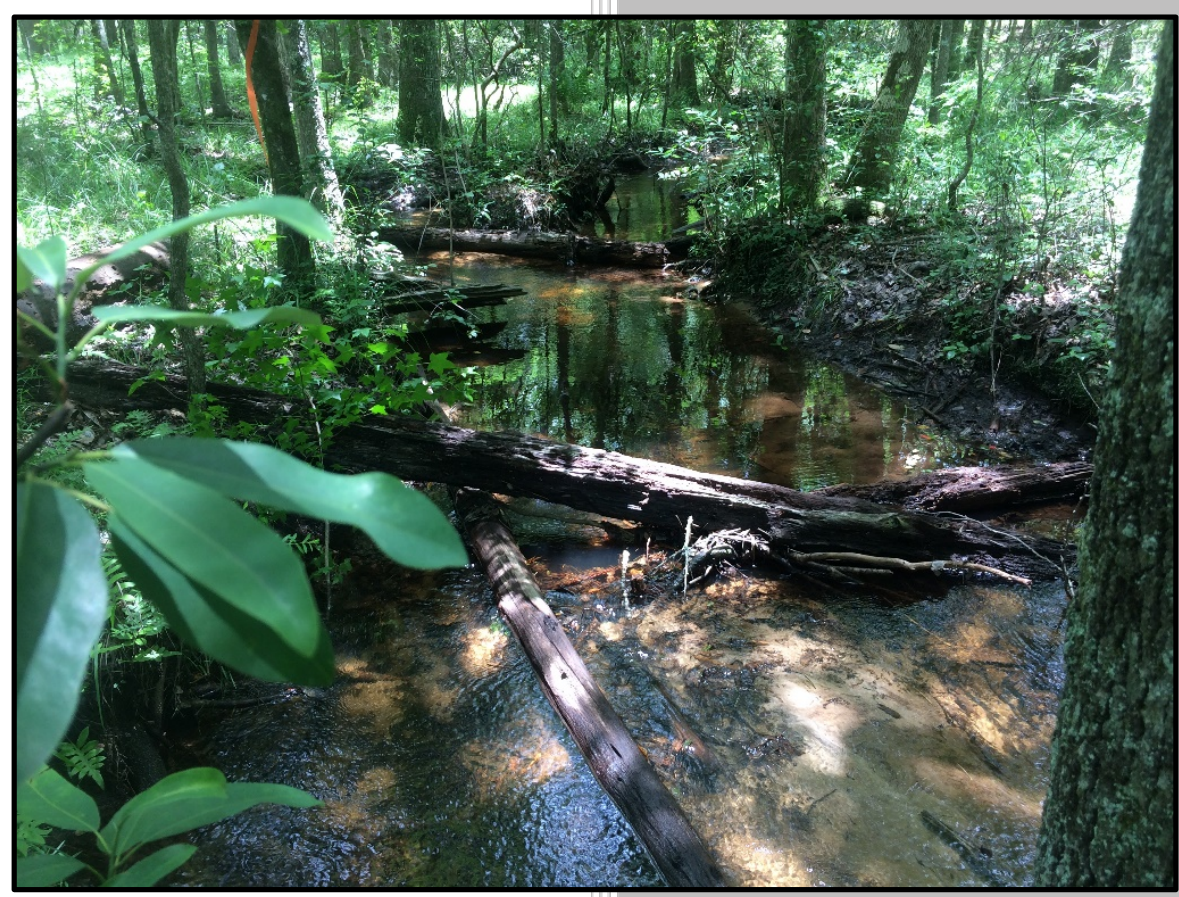

Approved for public release.

N.A. Griffiths

B.S. Helms

J.W. Feminella

S. Bickley

D.J. Isenberg

May 2020 


\title{
DOCUMENT AVAILABILITY
}

Reports produced after January 1, 1996, are generally available free via US Department of Energy (DOE) SciTech Connect.

Website www.osti.gov

Reports produced before January 1, 1996, may be purchased by members of the public from the following source:

\author{
National Technical Information Service \\ 5285 Port Royal Road \\ Springfield, VA 22161 \\ Telephone 703-605-6000 (1-800-553-6847) \\ TDD 703-487-4639 \\ Fax 703-605-6900 \\ E-mail info@ntis.gov \\ Website http://classic.ntis.gov/
}

Reports are available to DOE employees, DOE contractors, Energy Technology Data Exchange representatives, and International Nuclear Information System representatives from the following source:

Office of Scientific and Technical Information

PO Box 62

Oak Ridge, TN 37831

Telephone 865-576-8401

Fax 865-576-5728

E-mail reports@osti.gov

Website http://www.osti.gov/contact.html

This report was prepared as an account of work sponsored by an agency of the United States Government. Neither the United States Government nor any agency thereof, nor any of their employees, makes any warranty, express or implied, or assumes any legal liability or responsibility for the accuracy, completeness, or usefulness of any information, apparatus, product, or process disclosed, or represents that its use would not infringe privately owned rights. Reference herein to any specific commercial product, process, or service by trade name, trademark, manufacturer, or otherwise, does not necessarily constitute or imply its endorsement, recommendation, or favoring by the United States Government or any agency thereof. The views and opinions of authors expressed herein do not necessarily state or reflect those of the United States Government or any agency thereof. 
ORNL/SPR-2020/1522

SERDP Project \#RC-2704

Environmental Sciences Division

\title{
EVALUATING THE LONG-TERM ECOLOGICAL RESPONSES TO RIPARIAN ECOSYSTEM RESTORATION AT THE FORT BENNING, GEORGIA MILITARY INSTALLATION
}

\author{
N.A. Griffiths \\ B.S. Helms \\ J.W. Feminella \\ S. Bickley \\ D.J. Isenberg
}

May 2020

Prepared by

OAK RIDGE NATIONAL LABORATORY

Oak Ridge, TN 37831-6283

managed by

UT-BATTELLE, LLC

for the

US DEPARTMENT OF ENERGY

under contract DE-AC05-00OR22725 



\section{TABLE OF CONTENTS}

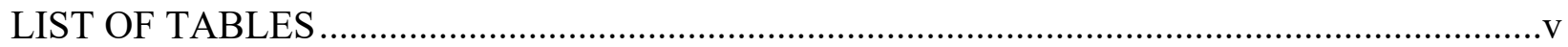

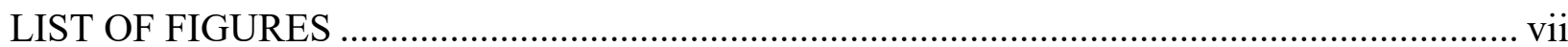

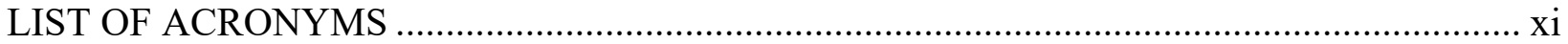

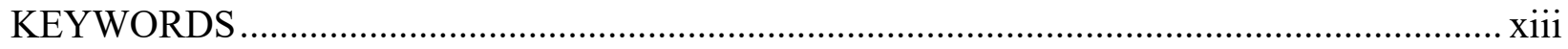

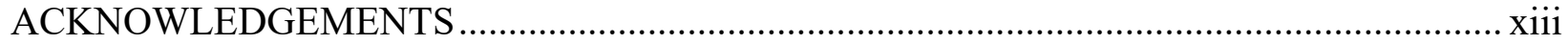

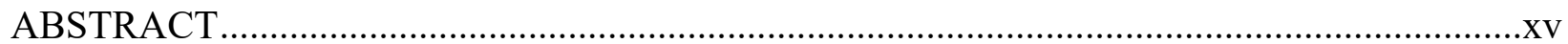

EXECUTIVE SUMMARY ...................................................................................... xvii

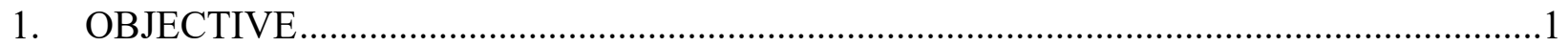

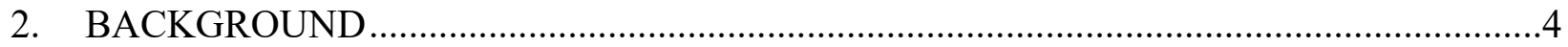

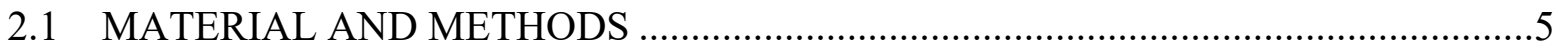

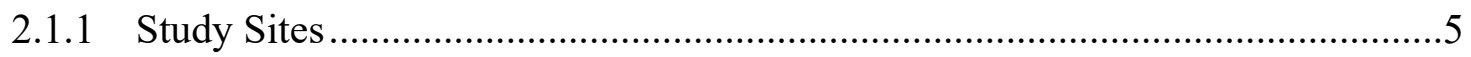

2.1.2 Experimental Design ........................................................................... 7

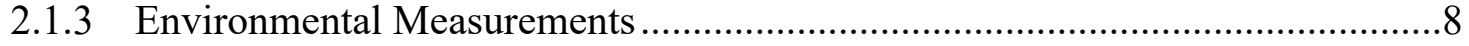

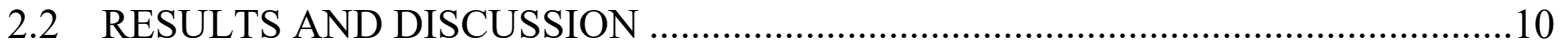

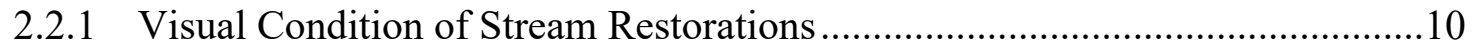

2.2.2 Coarse Woody Debris ........................................................................ 11

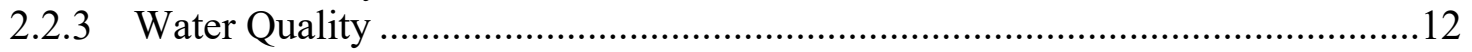

2.2.4 Ammonium Uptake ......................................................................... 17

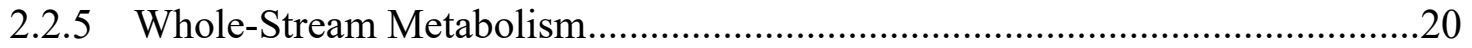

2.2.6 Benthic Particulate Organic Matter..............................................................22

2.2.7 Stream Macroinvertebrates.......................................................................26

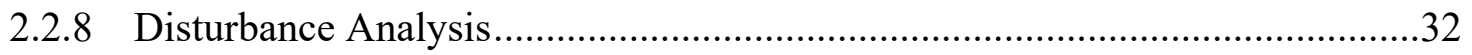

3. CONCLUSIONS AND IMPLICATIONS FOR FUTURE

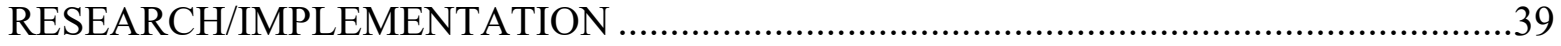

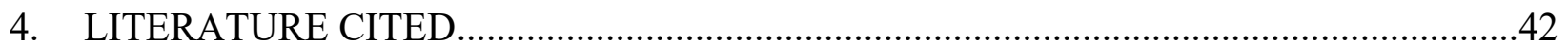

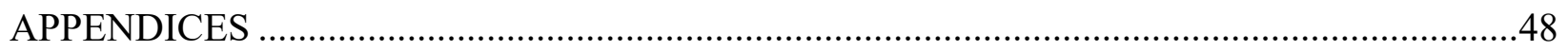





\section{LIST OF TABLES}

Table 1 - Summary of initial (1-3 year) ecological responses to instream restoration relative to pre-treatment conditions (Mulholland et al. 2007), and predicted $\sim 14$ year restoration responses relative to pre-treatment conditions.

Table 2 - Descriptions of the 7 study sites and restoration types used in the current study (\% disturbance data are from Mulholland et al. [2007]).

Table 3 - Watershed disturbance intensity (\% catchment), as calculated in Maloney et al. (2005) and using the 2016 National Land Cover Dataset (NLCD), across the 7 study sites

Table 4 - Results from the linear regression analyses (adjusted $\mathrm{r}^{2}$ - and $\mathrm{p}$-values) of the effects of \% watershed disturbance on mean maximum daily dissolved oxygen (DO) deficit and mean daily DO deficit amplitude by year, season, and period (prerestoration [PRE; 2001-2003], immediately post-restoration [PR; 2004-2006], and 14-y post-restoration [14-y PR; 2017-2018]). Bold text represents significant pvalues $(\mathrm{p} \leq 0.05)$, and italicized text represents marginally significant $\mathrm{p}$-values $(>$ 0.05 and $\leq 0.1)$.

Table 5 - Results from the linear regression analyses (adjusted $\mathrm{r}^{2}$ - and $\mathrm{p}$-values) of the effects of $\%$ watershed disturbance on water quality metrics (total suspended solids [TSS], nitrate $\left[\mathrm{NO}_{3}\right]$, ammonium $\left[\mathrm{NH}_{4}\right]$, soluble reactive phosphorus [SRP], and dissolved organic carbon [DOC] concentrations) across pre-restoration (PRE; 2001-2003), immediately post-restoration (PR; 2004-2006), and 14-y postrestoration (14-y PR; 2017-2018) periods. Bold text represents significant pvalues $(\mathrm{p} \leq 0.05)$, and italicized text represents marginally significant $\mathrm{p}$-values $(>$ 0.05 and $\leq 0.1)$. 



\section{LIST OF FIGURES}

Figure ES.1 - Ephemeral drainage restoration (left) and instream habitat restoration through coarse woody debris additions (right). xviii

Figure ES.2 - Photo of a coarse woody debris dam in Kings Mill Creek, an instream restored site at Fort Benning Military Installation ..XX

Figure ES.3 - Areal coverage (\%) of coarse woody debris (CWD) in stream beds in the three unrestored and four restored streams that received CWD additions in the pre-restoration period (2001-2003; blue bars), immediately after restoration (2004-2007; orange bars), and 14-y post-restoration (2017-2018; purple bars). ..XX

Figure ES.4 - Dissolved organic carbon concentrations (DOC; mg C/L) [top panel] and total suspended solid concentrations (TSS; $\mathrm{mg} / \mathrm{L}$ ) [bottom panel] in stream water in the three unrestored streams and four restored streams in the pre-restoration period (2001-2003; blue boxes), immediately after restoration (2004-2007; orange boxes), and 14-y post-restoration (2017-2018; purple boxes). $\mathrm{xxi}$

Figure ES.5 - Ammonium uptake rate $\left(\mathrm{mg} \mathrm{N} / \mathrm{m}^{2} / \mathrm{d}\right)$ in the three unrestored streams and four restored streams that received instream coarse woody debris (CWD) restorations in the fall/early winter season in the pre-restoration period (immediately before restoration in October 2003; blue bars), immediately after restoration (2003-2005; orange bars), and 14-y post-restoration (2017-2018; purple bars). $\mathrm{xxi}$

Figure ES. 6 - Mean (+ standard deviation) benthic particulate organic matter (\%BPOM) in the sediment of three unrestored streams and four restored streams that received instream coarse woody debris (CWD) restorations in the pre-restoration period (2001-2002; blue bars), immediately after restoration (2004-2007; orange bars), and 14-y post-restoration (2017-2018; purple bars) across all seasons. xxii

Figure ES.7 - Mean (+ standard deviation) total macroinvertebrate density (\# individuals $/ \mathrm{m}^{2}$ ) in the three unrestored streams and four restored streams that received instream coarse woody debris (CWD) restorations in the pre-restoration period (2001-2002; blue bars), immediately after restoration (2004-2006; orange bars), and 14-y post-restoration (2017-2018; purple bars) across all seasons............... xxii

Figure ES.8 - Relationships between \% watershed disturbance and water quality metrics (top left to bottom right panels: total suspended solid [TSS], nitrate $\left[\mathrm{NO}_{3}\right]$, ammonium $\left[\mathrm{NH}_{4}\right]$, soluble reactive phosphorus [SRP], and dissolved organic carbon [DOC] concentrations) for the entire 14-y dataset. xxiii

Figure 1 - Ephemeral drainage restoration (left) and instream woody debris addition restoration (right).

Figure 2 - Location of the seven study sites at Fort Benning Military Installation, Georgia. 6

Figure 3 - Photos of the 7 study streams, taken in May-June 2017.

Figure 4 -Close-up photos of debris dams in 3 of the 4 instream restored sites, taken in May-June 2017.

Figure 5 - Areal coverage (\%) of coarse woody debris (CWD) in stream beds in the three unrestored streams (HB, SB4, BC) and four restored streams (SB3, LPK, KM1, SB2) that received CWD additions (instream restorations) over time. 
Figure 6 - Box plots summarizing dissolved organic carbon concentrations (DOC; mg $\mathrm{C} / \mathrm{L}$ ) [top panel] and total suspended solid concentrations (TSS; mg/L) [bottom panel] in stream water in the three unrestored streams (HB, SB4, BC) and four restored streams (SB3, LPK, KM1, SB2) that received instream coarse woody debris (CWD) additions.

Figure 7 - Box plots summarizing specific conductivity $(\mu \mathrm{S} / \mathrm{cm})$ [top panel] and $\mathrm{pH}$ [bottom panel] of stream water in the three unrestored streams (HB, SB4, BC) and four restored streams (SB3, LPK, KM1, SB2) that received instream coarse woody debris (CWD) additions.

Figure 8 - Box plots summarizing ammonium [top panel], nitrate [second panel], dissolved inorganic nitrogen [third panel], and soluble reactive phosphorus [bottom panel] concentrations ( $\mu \mathrm{g} \mathrm{N}$ or $\mathrm{P} / \mathrm{L}$ ) in stream water in the three unrestored streams (HB, SB4, BC) and four restored streams (SB3, LPK, KM1, SB2) that received instream coarse woody debris (CWD) additions.

Figure 9 - Mean (+ standard error) areal uptake rates $\left(U ; \mathrm{mg} \mathrm{N} / \mathrm{m}^{2} / \mathrm{d}\right)$ of ammonium in fall immediately before (2003 pre) and after (2003 post) coarse woody debris (CWD) additions, and one (2004), two (2005), fourteen (2017), and fifteen (2018) years post-CWD additions in unrestored (blue) and restored (orange) streams.

Figure 10 - Ammonium uptake length (m) [top panel], ammonium uptake velocity $(\mathrm{mm} / \mathrm{s})$ [middle panel], and ammonium uptake rate $\left(\mathrm{mg} \mathrm{N} / \mathrm{m}^{2} / \mathrm{d}\right)$ [bottom panel] in the three unrestored streams (HB, SB4, BC) and four restored streams (SB3, LPK, $\mathrm{KM} 1, \mathrm{SB} 2$ ) that received instream coarse woody debris (CWD) restorations.

Figure 11 - Mean (+ standard error) whole-stream metabolism indicators, dissolved oxygen (DO) deficit daily amplitude (mg/L) (an indicator of gross primary production) [top panel] and maximum daily DO deficit $(\mathrm{mg} / \mathrm{L})$ (an indicator of ecosystem respiration) [bottom panel], for all seasons across all years in unrestored (blue) and restored (orange) streams.

Figure 12 - Mean (+ standard error) maximum daily dissolved oxygen (DO) deficit $(\mathrm{mg} / \mathrm{L})$, an indicator of ecosystem respiration [top panel], and the daily amplitude of the DO deficit $(\mathrm{mg} / \mathrm{L})$, an indicator of gross primary production [bottom panel], in the three unrestored streams (HB, SB4, BC) and four restored streams (SB3, LPK, KM1, SB2) that received instream coarse woody debris (CWD) additions in spring across years.

Figure 13 - Mean (+ standard error) maximum daily dissolved oxygen (DO) deficit $(\mathrm{mg} / \mathrm{L})$, an indicator of ecosystem respiration [top panel], and the daily amplitude of the DO deficit $(\mathrm{mg} / \mathrm{L})$, an indicator of gross primary production [bottom panel], in the three unrestored streams (HB, SB4, BC) and four restored streams (SB3, LPK, KM1, SB2) that received instream coarse woody debris (CWD) additions in summer across years.

Figure 14 - Mean (+ standard error) maximum daily dissolved oxygen (DO) deficit $(\mathrm{mg} / \mathrm{L})$, an indicator of ecosystem respiration [top panel], and the daily amplitude of the DO deficit $(\mathrm{mg} / \mathrm{L})$, an indicator of gross primary production [bottom panel], in the three unrestored streams (HB, SB4, BC) and four restored streams (SB3, LPK, KM1, SB2) that received instream coarse woody debris (CWD) additions in fall across years. 
Figure 15 - Mean ( + standard deviation) percent of stream sediments as benthic particulate organic matter $(\% \mathrm{BPOM})$ in unrestored $(\mathrm{HB}, \mathrm{SB} 4, \mathrm{BC})$ and restored (SB3, LPK, KM1, SB2) streams in the pre-restoration period (2001-2002; blue bars), immediately after restoration (2004-2007; orange bars), and 14-y postrestoration (2017-2018; purple bars).

Figure 16 - Mean ( + standard deviation) percent of stream sediments as benthic particulate organic matter (\%BPOM) in unrestored (blue) and restored (orange) streams in each of 5 sampling seasons (August 2017 [Summer1], November 2017 [Fall], February 2018 [Winter], April 2018 [Spring], and September 2018 [Summer2]) in the 14-y post-restoration period.

Figure 17 - Mean (+ standard deviation) Ephemeroptera, Plecoptera, and Trichoptera density $\left(\mathrm{EPT} / \mathrm{m}^{2}\right)$ in unrestored (blue) and restored (orange) streams in each of 5 sampling seasons (August 2017 [Summer1], November 2017 [Fall], February 2018 [Winter], April 2018 [Spring], and September 2018 [Summer2]) in the 14-y post-restoration period.

Figure 18 - Mean (+ standard deviation) Ephemeroptera, Plecoptera, and Trichoptera density $\left(\mathrm{EPT} / \mathrm{m}^{2}\right)$ in unrestored (HB, SB4, BC) and restored (SB3, LPK, KM1, SB2) streams in the pre-restoration period (2001-2003; blue bars), immediately after restoration (2004-2006; orange bars), and 14-y post-restoration (2017-2018; purple bars).

Figure 19 - Mean (+ standard deviation) percentage of Ephemeroptera, Plecoptera, and Trichoptera taxa (\%EPT) in unrestored (blue) and restored (orange) streams in each of 5 sampling seasons (August 2017 [Summer1], November 2017 [Fall], February 2018 [Winter], April 2018 [Spring], and September 2018 [Summer2]) in the 14-y post-restoration period.

Figure 20 - Mean (+ standard deviation) percentage of Ephemeroptera, Plecoptera, and Trichoptera taxa (\%EPT) in unrestored (HB, SB4, BC) and restored (SB3, LPK, KM1, SB2) streams in the pre-restoration period (2001-2002; blue bars), immediately after restoration (2004-2006; orange bars), and 14-y post-restoration (2017-2018; purple bars). Data are stream averages across all seasons.

Figure 21 - Mean (+ standard deviation) total macroinvertebrate density (\# individuals $/ \mathrm{m}^{2}$ ) in unrestored (blue) and restored (orange) streams in each of 5 sampling seasons (August 2017 [Summer1], November 2017 [Fall], February 2018 [Winter], April 2018 [Spring], and September 2018 [Summer2]) in the 14-y post-restoration period.

Figure 22 - Mean (+ standard deviation) total macroinvertebrate density (\# individuals $/ \mathrm{m}^{2}$ ) in unrestored (HB, SB4, BC) and restored (SB3, LPK, KM1, SB2) streams in the pre-restoration period (2001-2002; blue bars), immediately after restoration (2004-2006; orange bars), and 14-y post-restoration (2017-2018; purple bars).

Figure 23 - Mean (+ standard deviation) macroinvertebrate taxonomic richness (\# of taxa) in unrestored (blue) and restored (orange) streams in each of 5 sampling seasons (August 2017 [Summer1], November 2017 [Fall], February 2018 [Winter], April 2018 [Spring], and September 2018 [Summer2]) in the 14-y postrestoration period. 
Figure 24 - Mean ( + standard deviation) macroinvertebrate taxonomic richness (\# of taxa) in unrestored (HB, SB4, BC) and restored (SB3, LPK, KM1, SB2) streams in the pre-restoration period (2001-2002; blue bars), immediately after restoration (2004-2006; orange bars), and 14-y post-restoration (2017-2018; purple bars).

Figure 25 - Mean (+ standard deviation) macroinvertebrate taxonomic diversity

(Shannon's $H^{\prime}$ ) in unrestored (blue) and restored (orange) streams in each of 5 sampling seasons (August 2017 [Summer1], November 2017 [Fall], February 2018 [Winter], April 2018 [Spring], and September 2018 [Summer2]) in the 14-y post-restoration period.

Figure 26 - Mean (+ standard deviation) macroinvertebrate taxonomic diversity

(Shannon's $H^{\prime}$ ) in unrestored (HB, SB4, BC) and restored (SB3, LPK, KM1, SB2) streams in the pre-restoration period (2001-2002; blue bars), immediately after restoration (2004-2006; orange bars), and 14-y post-restoration (2017-2018; purple bars).

Figure 27 - Relationships between \% watershed disturbance, as calculated in Maloney et al. (2005), and (A) maximum dissolved oxygen (DO) deficit (an indicator of ecosystem respiration, in $\mathrm{mg} / \mathrm{L}$ ) in the pre-restoration period (2001-2003), (B) daily DO deficit amplitude (an indicator of gross primary production, in $\mathrm{mg} / \mathrm{L}$ ) in the pre-restoration period, (C) maximum DO deficit immediately after restoration (2004-2006), (D) daily DO deficit amplitude immediately after restoration, (E) maximum daily DO deficit 14-y post-restoration (2017-2018), and (F) daily DO deficit amplitude 14-y post-restoration.

Figure 28 - Relationships between \% watershed disturbance and (A) areal uptake rate of ammonium $\left(U ; \mathrm{mg} \mathrm{N} / \mathrm{m}^{2} / \mathrm{d}\right)$ in the pre-restoration period (2001-2003), (B) uptake velocity of ammonium $\left(v_{f}, \mathrm{~mm} / \mathrm{s}\right)$ in the pre-restoration period, (C) $U$ immediately after restoration (2004-2006), (D) $v_{f}$ immediately after restoration, (E) $U$ 14-y post-restoration (2017-2018), and (F) $v_{f} 14-y$ post-restoration.

Figure 29 - Relationships between \% watershed disturbance and ammonium uptake velocity ( $v_{f}$ in $\mathrm{mm} / \mathrm{s}$; top panel) and areal uptake rate of ammonium ( $U$ in $\mathrm{mg}$ $\mathrm{N} / \mathrm{m}^{2} / \mathrm{d}$; bottom panel) across all streams and years.

Figure 30 - Relationships between \% watershed disturbance and water quality metrics (top left to bottom right panels: total suspended solid [TSS], nitrate $\left[\mathrm{NO}_{3}\right]$, ammonium $\left[\mathrm{NH}_{4}\right]$, soluble reactive phosphorus [SRP], and dissolved organic carbon [DOC] concentrations) for the entire 14-y dataset. 


\section{LIST OF ACRONYMS}

14-y PR - 14-Years Post-Restoration

AFDM - Ash-Free Dry Mass

ANOVA - Analysis of Variance

BACI - Before After Control Impact (statistical design)

$\mathrm{BC}$ - Bonham Creek (ephemeral restoration and unrestored control site for instream)

BPOM - Benthic Particulate Organic Matter

CWD - Coarse Woody Debris

DIN - Dissolved Inorganic Nitrogen

DO - Dissolved Oxygen

DOC - Dissolved Organic Carbon

DoD - Department of Defense

EPA - Environmental Protection Agency

EPT - Ephemeroptera, Plecoptera, Trichoptera

ER - Ecosystem Respiration

ESTCP - Environmental Security Technology Certification Program

FBMI - Fort Benning Military Installation

GLMM - General Linear Mixed Effects Model

GPP - Gross Primary Production

HB - Hollis Branch (unrestored control site)

HD - Hester-Dendy sampler

KM1 - Kings Mill Creek (instream and ephemeral restoration site)

LPK - Little Pine Knot (instream restoration site)

$\mathrm{NaCl}$ - Sodium chloride

$\mathrm{NH}_{4} \mathrm{Cl}$ - Ammonium chloride

NLCD - National Land Cover Dataset

NU - No (measurable) Uptake

ORNL - Oak Ridge National Laboratory

PR - Post-Restoration Period (directly after CWD additions)

PRE - Pre-Restoration Period

SB2 - Sally Branch Tributary 2 (instream and ephemeral restoration site)

SB3 - Sally Branch Tributary 3 (instream restoration site)

SB4 - Sally Branch Tributary 4 (unrestored control site)

SE - Standard Error

SERDP - Strategic Environmental Research and Development Program

SON - Statement of Need

SRP - Soluble Reactive Phosphorus

TSS - Total Suspended Solids

US - United States

USGS - United States Geological Survey 



\section{KEYWORDS}

restoration; coarse-woody debris additions; stream ecosystem processes; long-term responses; lagged effects; water quality; nutrient uptake; gross primary production; ecosystem respiration; benthic particulate organic matter; macroinvertebrate indicators; Ephemeroptera, Plecoptera, Trichoptera (EPT) taxa; Fort Benning Military Installation; Coastal Plain; southeastern US.

\section{ACKNOWLEDGEMENTS}

This research was supported by a grant from the Department of Defense's Strategic Environmental Research and Development Program. Oak Ridge National Laboratory (ORNL) is managed by UT-Battelle, LLC, for the U.S. Department of Energy under contract DE-AC0500OR22725. This report was assembled by PI Natalie Griffiths (ORNL), co-PI Brian Helms (Troy University), senior advisor Jack Feminella (Auburn University), and graduate students Sam Bickley (Auburn University) and Dan Isenberg (Troy University). We thank J. Parker from the Fort Benning Land Management Branch for site access and fieldwork scheduling, J. Houser, K. Maloney, R. Mitchell, and B. Roberts for providing data from the original study, A. Fortner and J. Phillips for technical assistance, and P. Matson for providing helpful comments on this report. Lastly, we thank all of the scientists, notably the late Pat Mulholland (original project PI), who worked on the original studies at Fort Benning Military Installation and laid the foundation for this research. 



\begin{abstract}
Introduction and Objectives: Riparian and instream restorations are commonly implemented to improve ecosystem condition. However, very few restoration activities are monitored for multiple years to assess long-term effectiveness. At the Department of Defense's Fort Benning Military Installation (FBMI) in west-central Georgia, two experimental restoration projects (ephemeral drainage revitalization and instream habitat augmentation [i.e., coarse woody debris (CWD) additions]) were implemented $\sim 14$ years ago with the goal of reducing environmental impacts of military training activities. A SERDP project found that instream restoration improved some aspects of ecosystem function and community structure but not others. The objective of the current study was to re-evaluate the effect of these restoration practices on stream ecosystem processes $\sim 14$ years after implementation.
\end{abstract}

Technical Approach: The current study was limited in scope compared to the original SERDP project; therefore, we focused on quantifying instream responses to both restoration types and assumed that benefits from ephemeral restoration may also be observed in streams. We measured a subset of the environmental indicators from the original study: water quality was measured monthly, and nutrient uptake, stream metabolism, benthic particulate organic matter (BPOM), and stream macroinvertebrates were measured seasonally. These measurements were carried out at 7 stream sites at FBMI: four sites with instream restorations and three sites that were unrestored. We closely followed the methodologies and sampling frequencies used in the original project so that pre-restoration (2001-2003) and immediate post-restoration (2004-2007) data were comparable to data collected 14-y post restoration (2017-2018; this study).

Results: Overall, the instream restorations had minimal long-term effects on stream ecosystem structure (water quality, BPOM, macroinvertebrates) and function (nutrient uptake, stream metabolism). CWD dams were still present in restored streams, but CWD abundance was similar across all streams, and thus some of the added CWD may have been buried over time. These restorations were motivated by a finding that ecosystem properties were impaired by upland disturbance at FBMI. We found that some stream metrics were still negatively impacted by watershed disturbance 14 years later, suggesting that small-scale restorations may not improve ecosystem condition if larger-scale impacts still persist.

Benefits: While this study found minimal long-term benefits of CWD additions, these results are likely not applicable to all stream ecosystems. Due to the dynamic nature of the stream bed in these sandy, Coastal Plain streams, CWD additions may only have short-term benefits. Implementing this restoration technology in Coastal Plain streams may require continual addition of CWD dams; this hypothesis remains to be tested. There are a paucity of studies that examine the long-term ( $>10$ year) efficacy of restoration technologies. However, despite the important knowledge gap that our study addresses, this evaluation was still limited as measurements only occurred for $\sim 1.5$ years, and thus did not capture ecosystem responses across a large range of climatic and environmental variation. Studies that evaluate the long-term efficacy of restoration over many years are important to pursue in the future. 

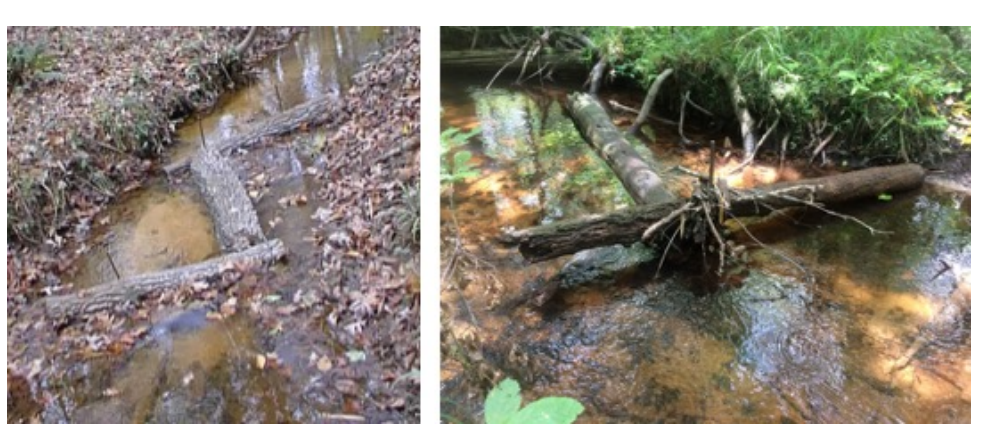

Real-world application: Photos of the instream restorations at FBMI immediately after installation

(left) and $\sim 14$ y later (right).

Photos were not taken in the same location. 


\section{EXECUTIVE SUMMARY}

Introduction: Streams and rivers provide numerous ecosystem services to humans. However, flowing waters can be impacted by a variety of anthropogenic activities because of the close proximity of humans to freshwater systems (i.e., $50 \%$ of the Earth's population live less than 3 $\mathrm{km}$ from freshwater; Kummu et al. 2011). These perturbations can impair water quality, alter water quantity, and negatively impact freshwater biodiversity (NRC 1992). In fact, almost half of small streams in the United States (US) are characterized as being in "poor condition" (US EPA 2006). Degraded environmental conditions often motivate stream and riparian restorations, with \$14-15 billion spent on stream and river restorations in the US over a 15-year period (Bernhardt et al. 2005).

Ecological restorations aim to return ecosystem properties to pre-disturbance conditions (NRC 1992), with the restoration mission, goals, and objectives based on site-specific circumstances (NRC 1992, Palmer et al. 2005). Stream restorations are most often focused on improving water quality, managing riparian zones and stabilizing stream banks, improving instream habitat for aquatic organisms, and facilitating fish passage (Bernhardt et al. 2005). However, the efficacy of stream restorations is not well documented because only $\sim 10 \%$ of restorations are monitored after implementation (Bond and Lake 2003, Roni et al. 2008, Bernhardt and Palmer 2011), and very few are monitored over long periods of time (i.e., $>10$ years; Roni et al. 2008, Tullos et al. 2009). Evaluation of stream restoration efficacy over both the short- and long-term is critical for assessing if stream restorations are effective at improving ecosystem conditions and are a worthwhile investment.

Numerous stream restoration techniques are implemented in practice, with the type of restoration selected based on the stressor(s), watershed characteristics, and restoration goals and objectives (NRC 1992, Bernhardt et al. 2005, Palmer et al. 2005). One commonly used stream restoration technique is instream habitat augmentation through the addition of large wood (i.e., coarse woody debris [CWD]) to stream channels. These CWD additions aim to provide habitat for benthic macroinvertebrates and fish, retain sediment, and create biogeochemical hotspots for a variety of ecosystem processes (e.g., nutrient cycling) (Bilby and Likens 1980, Smock et al. 1989, Bilby and Ward 1991, Roberts et al. 2007a, Craig et al. 2008, Roni et al. 2015). Similar to most ecological restorations, the efficacy of CWD additions is not well established due to a lack of comprehensive evaluations (Roni et al. 2002, Thompson 2005).

Objectives: Various military training activities (e.g., dismounted infantry tactics, tracked vehicle maneuvers, heavy weapon use, and airborne training drop zones) can have environmental impacts on Department of Defense (DoD) lands (USAIC 2001, Dale et al. 2002). At the DoD's Fort Benning Military Installation (FBMI) in Georgia, two experimental restoration projects were implemented $\sim 14$ years ago with the goal of reducing the effects of military activities on riparian and stream ecosystems. These restoration practices included ephemeral drainage revitalization and instream habitat augmentation (Figure ES.1). Ephemeral drainage restoration involved closing point-source inputs of sediment, stabilizing stream banks, and planting grasses and longleaf pine trees. Instream habitat restoration involved the addition of CWD dams along stream reaches. A Strategic Environmental Research and Development Program (SERDP)funded project measured the pre-treatment (2001-2003) and post-treatment (2003-2007) 
responses to restoration, and found that restoration improved some, but not all, aspects of ecosystem function and structure. Specifically, instream restoration increased ecosystem respiration rates, increased ammonium uptake rates, and changed some aspects of the macroinvertebrate communities. However, there were no effects on water quality and some other measures of macroinvertebrates possibly because these components of the stream ecosystems were slower to respond to CWD additions.
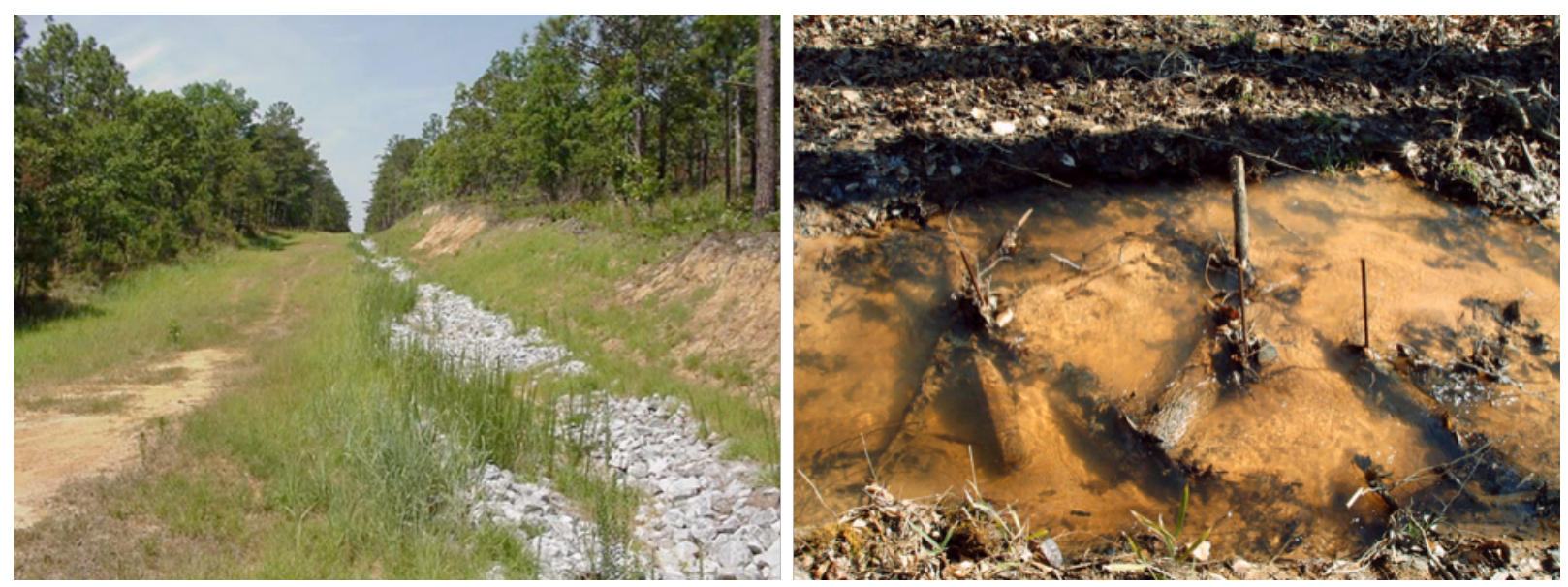

Figure ES.1 - Ephemeral drainage restoration (left) and instream habitat restoration through coarse woody debris additions (right). Photos are from original project files.

The objective of the current study was to re-evaluate the effects of two restoration practices on stream ecosystem processes $\sim 14$ years after implementation.

The specific objectives were to:

1) determine if the improvements to ecosystem condition that were observed immediately (1-3 years) after restoration were:

a) still in an improved state $\sim 14$ years post-restoration, or

b) were no longer showing improvements (i.e., return to pre-treatment conditions).

2) determine if the ecosystem parameters that did not change immediately (1-3 years) after restoration have:

a) since responded to restoration, or

b) still showed no change with restoration.

The current project was limited in scope compared to the original SERDP project. Thus, we focused on measuring a subset of environmental characteristics in this evaluation, some of which responded to initial restoration and others that did not. Further, we focused on quantifying instream responses to both restoration types as benefits observed from ephemeral restoration (e.g., decreased sedimentation rate) may be observed in the stream channels (e.g., decreased suspended solid concentrations). Studies that evaluate the long-term efficacy of ecological restorations are very rare. Thus, this project provides critical information on the longevity and efficacy of restorations. Further, these findings can be used to determine if these restoration technologies are worthwhile investments for DoD installations interested in restoring impaired watersheds. 
Technical Approach: This study took place at 7 sites at FBMI: four sites that received instream restorations in 2003-2004 and three sites that served as unrestored controls. Of these sites, two instream restoration sites received ephemeral drainage restoration, as did one unrestored control site. Pre-restoration conditions were monitored by the original SERDP project from 2001-2003, and post-restoration monitoring occurred from 2004-2007. We revisited these same 7 streams $\sim 14$ years after restoration, from May 2017 to January 2019, and measured physical, chemical, and biological processes in all 7 streams either monthly or seasonally. A subset of the environmental indicators measured in the original study were selected, and methodologies and sampling frequencies closely followed those in the original SERDP project so that pre- and immediate post-restoration data could be compared to data collected 14-y post restoration. Samples for water quality analyses were collected monthly, and ammonium uptake, stream metabolism metrics, benthic particulate organic matter (BPOM), and macroinvertebrate community metrics were measured seasonally ( 5 seasons total). We also quantified CWD abundance in all 7 streams.

Results and Discussion: The overall conclusion from this study is that instream restorations (i.e., CWD additions that took place $\sim 14$ years ago) had minimal long-term effects on stream ecosystem structure (i.e., water quality, BPOM, macroinvertebrates) and function (i.e., nutrient uptake, stream metabolism). While CWD dams were still visible in restored streams (Figure ES.2) and the \% cover of CWD increased in all streams compared to the original project, CWD abundance was not higher in restored vs unrestored streams 14-y post-restoration (Figure ES.3).

In general, there were no long-term effects of restoration on water quality metrics (Figure ES.4). However, total suspended solid concentrations were higher and dissolved organic carbon concentrations were lower in restored vs unrestored streams, possibly because sampling sometimes occurred under variable flow conditions in a given month when access to some sites was restricted due to military training activities. There were also no long-term effects of CWD additions on stream ecosystem processes (i.e., ammonium uptake and stream metabolism metrics) despite these metrics increasing initially after CWD was added to streams (Figure ES.5). Finally, there were no consistent long-term effects of CWD additions on BPOM and macroinvertebrate community metrics (Figures ES.6 and ES.7). Most measured stream processes showed strong seasonal and interannual variation, and also varied across streams, possibly reflecting environmental and climatic drivers acting across multiple spatial and temporal scales (e.g., seasonality in light availability and temperature, wet vs dry years, etc.).

A primary motivation for these restorations at FBMI was a prior finding that stream ecosystem structure and function was impaired in watersheds with higher upland disturbance (Houser et al. 2005, Mulholland et al. 2005, Roberts et al. 2007a). An analysis of land cover data suggests that watershed disturbance has not changed substantially over the past $\sim 14$ years at FBMI, and some stream metrics were still negatively impacted by watershed disturbance (Figure ES.8); however, responses varied by ecosystem metric, season, and restoration period. Overall, watershed disturbance still appears to be an important driver of stream ecosystem condition at FBMI, suggesting that smaller-scale restorations such as CWD additions may not be effective in the long term if the larger-scale stressors are not also addressed (NRC 1992, Craig et al. 2008, Roni et al. 2008, Bernhardt and Palmer 2011). 


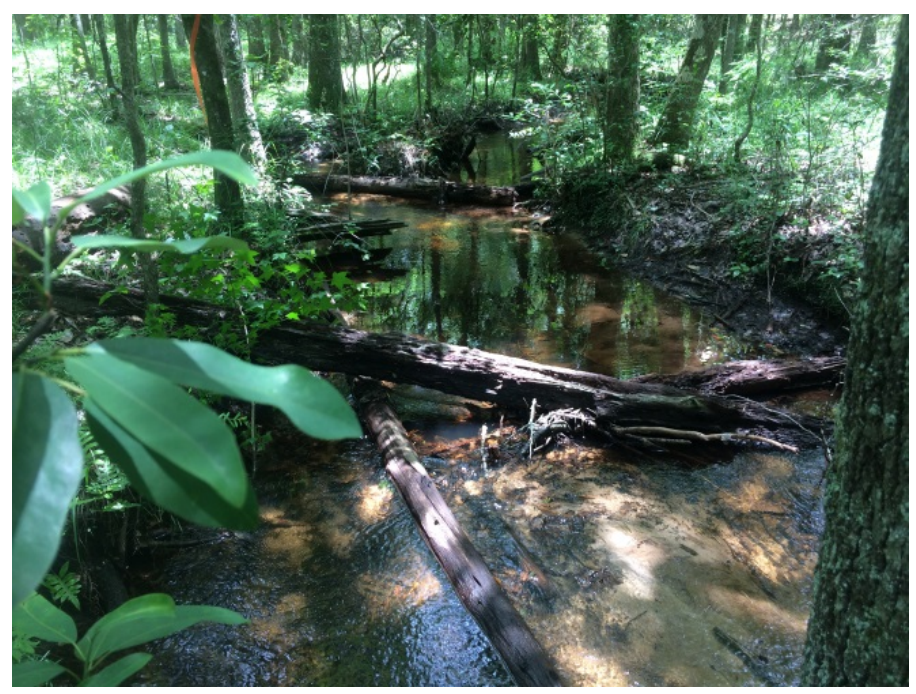

Figure ES.2 - Photo of a coarse woody debris dam in Kings Mill Creek, an instream restored site at Fort Benning Military Installation. The photo was taken $\sim 14$ years after instream restoration at this site.

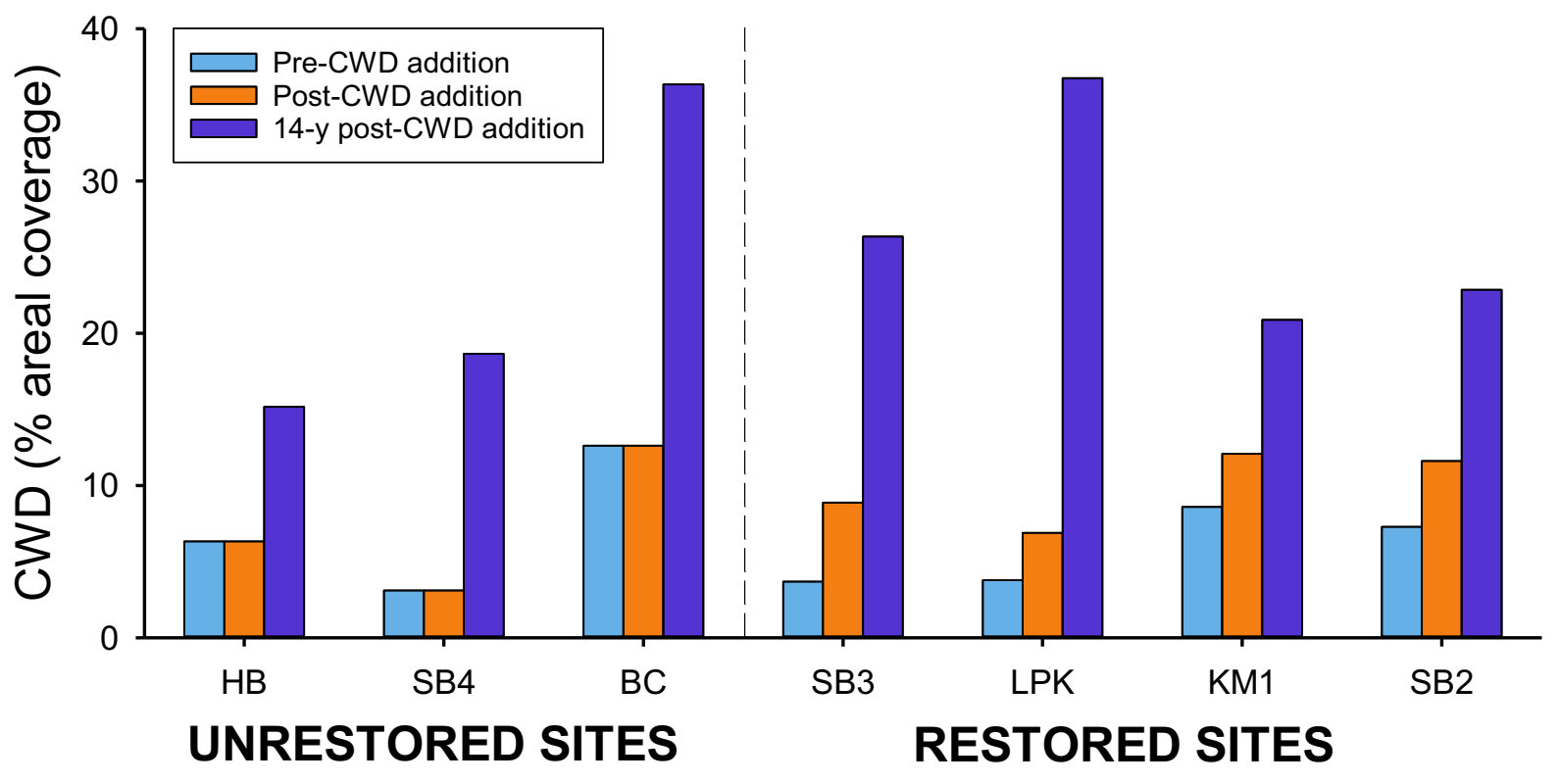

Figure ES.3 - Areal coverage (\%) of coarse woody debris (CWD) in stream beds in the three unrestored and four restored streams that received CWD additions in the prerestoration period (2001-2003; blue bars), immediately after restoration (2004-2007; orange bars), and 14-y post-restoration (2017-2018; purple bars). 

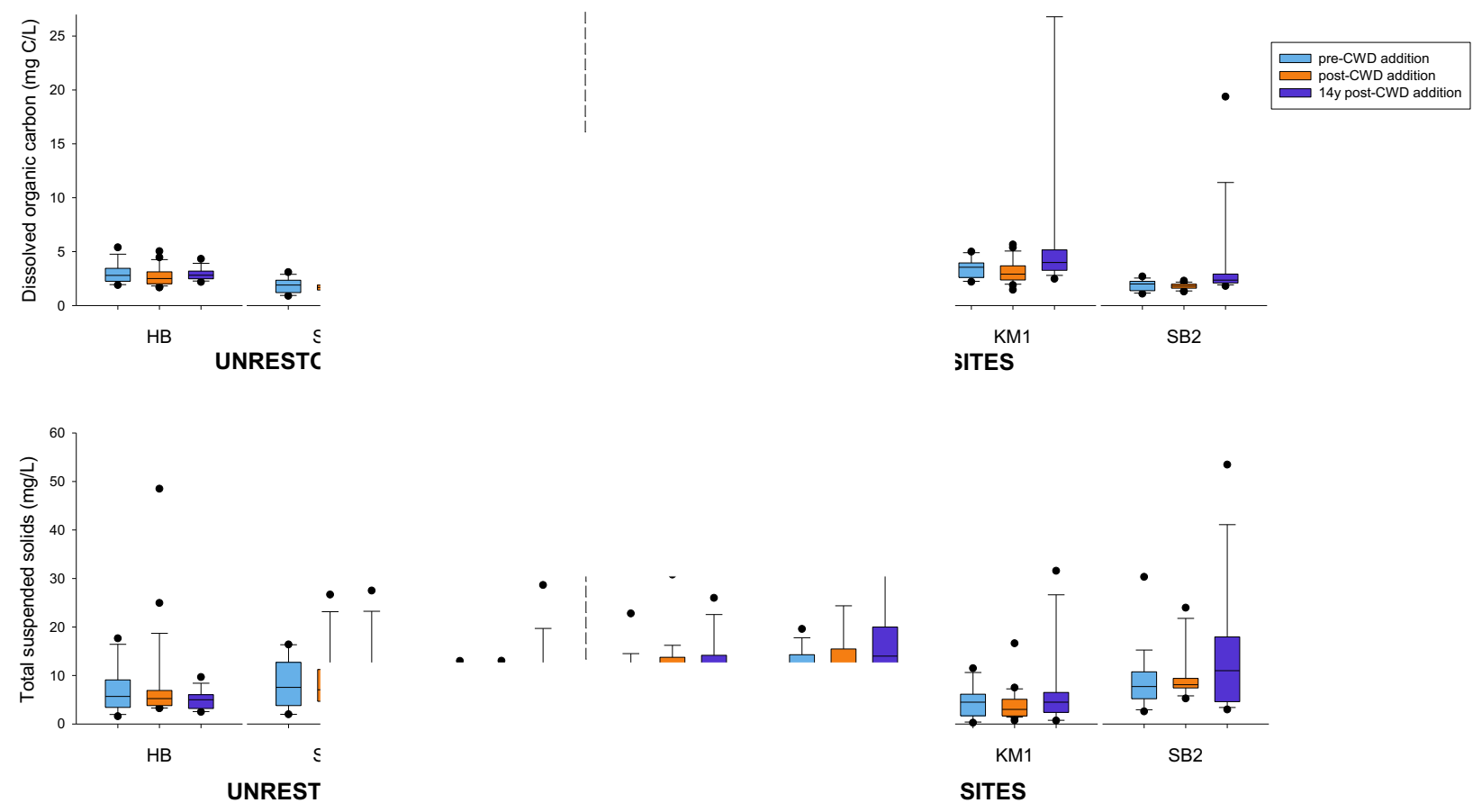

Figure ES.4 - Dissolved organic carbon concentrations (DOC; mg C/L) [top panel] and total suspended solid concentrations (TSS; $\mathrm{mg} / \mathrm{L}$ ) [bottom panel] in stream water in the three unrestored streams and four restored streams in the pre-restoration period (20012003; blue boxes), immediately after restoration (2004-2007; orange boxes), and 14-y postrestoration (2017-2018; purple boxes). Two DOC outliers, one at LPK (32 mg/L) and the other at KM1 $(60.9 \mathrm{mg} / \mathrm{L})$, were not included in the figure.

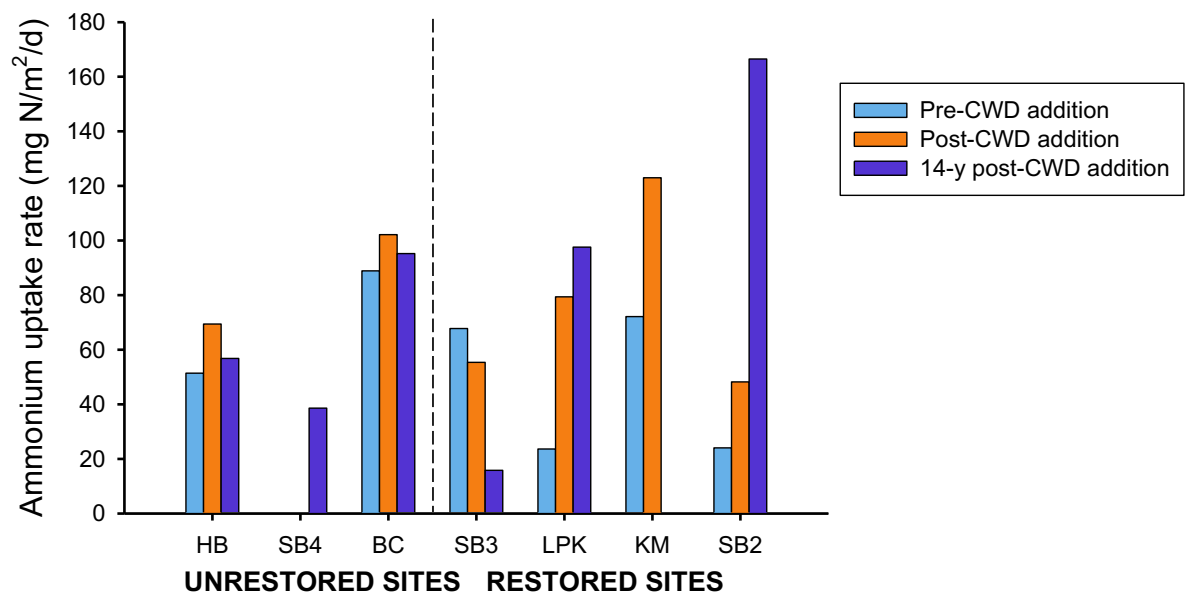

Figure ES.5 - Ammonium uptake rate $\left(\mathrm{mg} \mathrm{N} / \mathrm{m}^{2} / \mathrm{d}\right)$ in the three unrestored streams and four restored streams that received instream coarse woody debris (CWD) restorations in the fall/early winter season in the pre-restoration period (immediately before restoration in October 2003; blue bars), immediately after restoration (2003-2005; orange bars), and 14-y post-restoration (2017-2018; purple bars). 


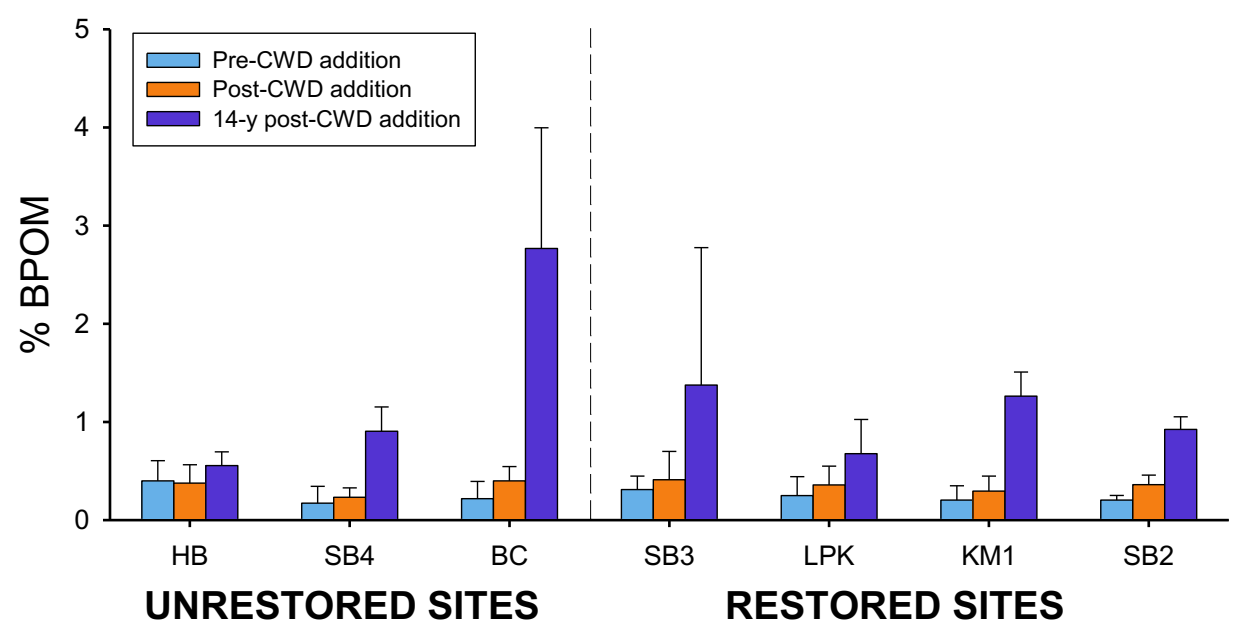

Figure ES.6 - Mean (+ standard deviation) benthic particulate organic matter (\%BPOM) in the sediment of three unrestored streams and four restored streams that received instream coarse woody debris (CWD) restorations in the pre-restoration period (20012002; blue bars), immediately after restoration (2004-2007; orange bars), and 14-y postrestoration (2017-2018; purple bars) across all seasons.

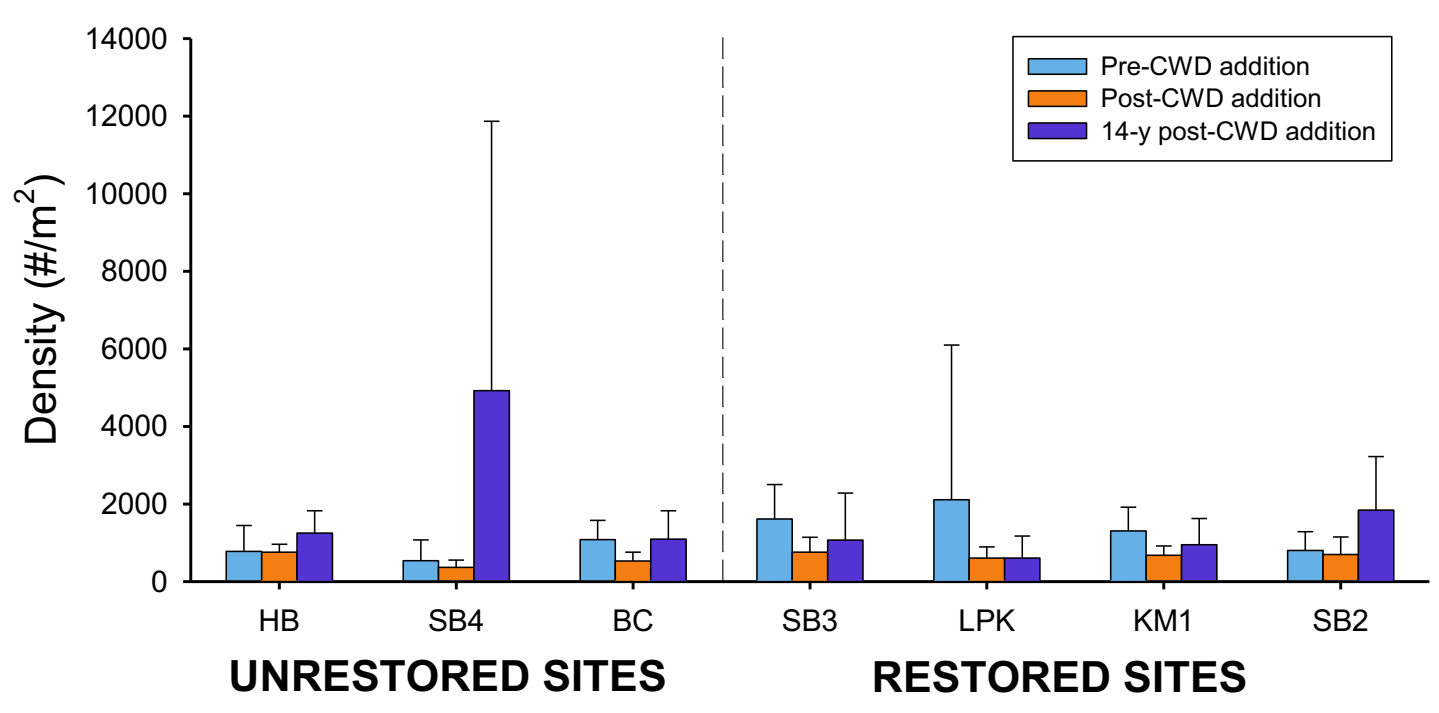

Figure ES.7 - Mean (+ standard deviation) total macroinvertebrate density (\# individuals $\left./ \mathbf{m}^{2}\right)$ in the three unrestored streams and four restored streams that received instream coarse woody debris (CWD) restorations in the pre-restoration period (20012002; blue bars), immediately after restoration (2004-2006; orange bars), and 14-y postrestoration (2017-2018; purple bars) across all seasons. 

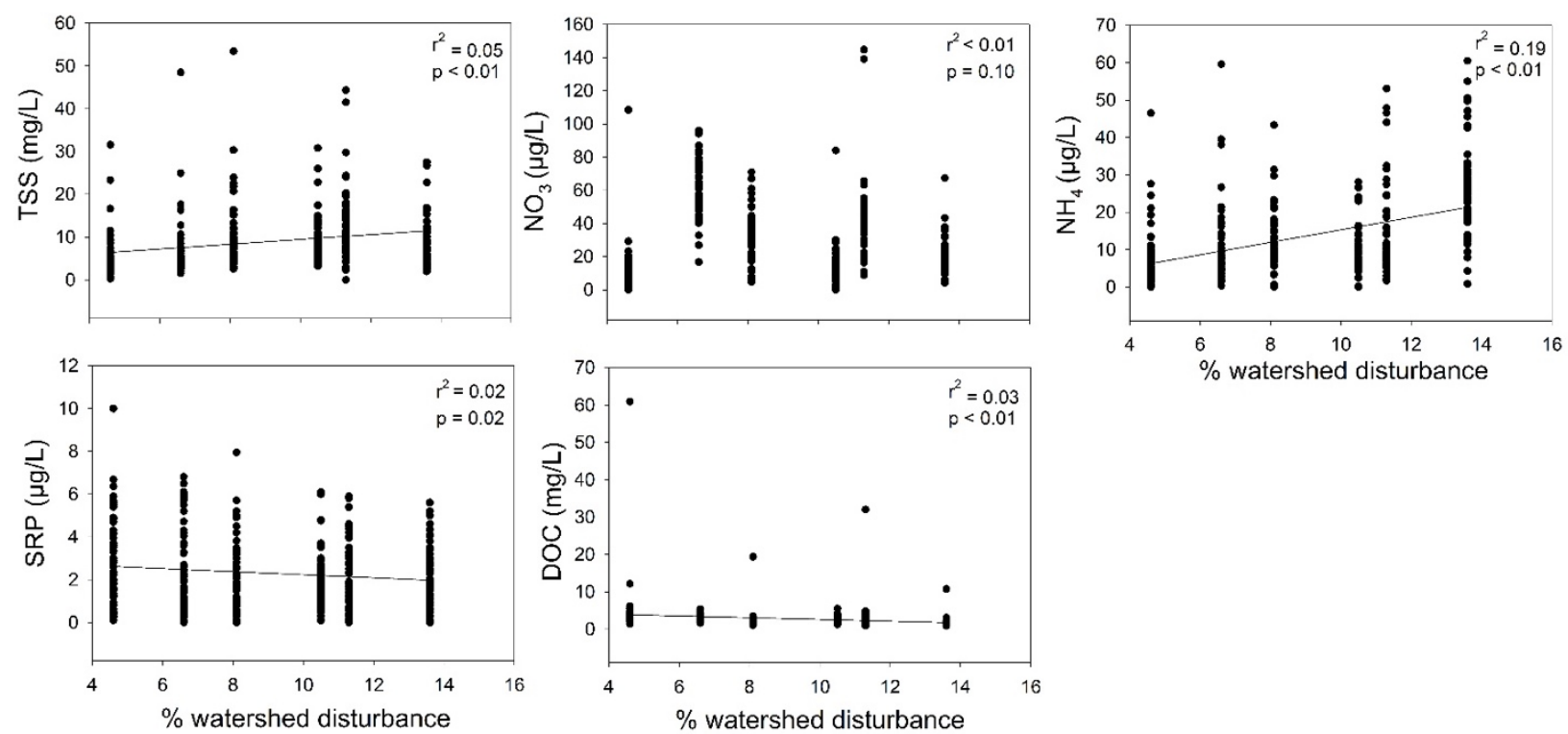

Figure ES.8 - Relationships between \% watershed disturbance and water quality metrics (top left to bottom right panels: total suspended solid [TSS], nitrate $\left[\mathrm{NO}_{3}\right.$ ], ammonium [NH4], soluble reactive phosphorus [SRP], and dissolved organic carbon [DOC] concentrations) for the entire 14-y dataset.

Implications for Future Research and Benefits: Measurement of select stream ecosystem structure and function metrics $\sim 14$ years after instream habitat augmentation suggests that there were minimal long-term benefits of these CWD installations as a restoration strategy. However, these findings may not be applicable to all stream ecosystems. Specifically, CWD additions to sandy-bottomed streams of the US Coastal Plain may be more susceptible to burial by sediments than in other ecoregions with more stable benthic substrates. Therefore, implementation of this restoration technology in Coastal Plain streams may require continual augmentation of CWD dams. Determining whether multiple additions of CWD to streams over time would be effective at improving stream condition is an important area for future research.

This study provided valuable information on the long-term efficacy of CWD additions; such evaluations are very rare in the field of restoration ecology. However, this evaluation was still limited as measurements only occurred over 1.5 years, and thus did not capture interannual variation in climatic and environmental factors that can be important drivers of stream ecosystem structure and function. For example, hydrologic flows during our 1.5-year measurement period ranged from historically high flows to historically low flows (United States Geological Survey [USGS] stream gage 02341800, Upatoi Creek near Columbus, Georgia). It is not known if the lack of long-term response to CWD additions was masked by these hydrologically variable conditions. Overall, the paucity of studies that evaluate the long-term efficacy of restorations over several years highlights a future need in the field (Palmer et al. 2005, Bernhardt et al. 2005, Wohl et al. 2005, Lake et al. 2007). 



\section{OBJECTIVE}

Implementation of riparian and instream restorations in the United States (US) is steadily increasing. The National River Restoration Science Synthesis estimated that from 1990-2005, \$14-15 billion was spent on continental US stream and river restorations alone (Bernhardt et al. 2005). However, despite this significant investment, very few restoration activities are monitored for long periods. Long-term monitoring of the ecosystem responses to restoration is critical to determine whether restoration 1) is an effective practice for improving ecosystem health, and 2) is a worthwhile investment of limited resources. At the Department of Defense (DoD) Fort Benning Military Installation (FBMI) in west-central Georgia, two experimental restoration projects were implemented $\sim 14$ years ago with the goal of reducing impacts of military activities (i.e., unpaved roads, dismounted infantry tactics, tracked vehicle maneuvers, etc.) on riparian and stream ecosystems. Two complementary restoration practices were implemented to mitigate these negative impacts; ephemeral drainage revitalization in three sites and instream habitat augmentation in four sites (Figure 1).

Ephemeral drainage restoration involved closing point-source sediment inputs, re-contouring and stabilizing channel sideslopes, sowing Coastal Bermuda grass on exposed soil, and planting longleaf pine in 2004-2005. Pre-restoration conditions were quantified from 2002-2005, and post-restoration monitoring continued through 2006. Sedimentation rate decreased, but many ecosystem parameters did not change post-restoration (Mulholland et al. 2007). The instream habitat restoration involved the creation of artificial woody debris dams along 100-150 m stream reaches in four sites in 2003 and 2004. Pre-treatment conditions were monitored for 2 years (2001-2003) and post-treatment conditions were measured for 3 years (2003-2007). Instream restoration improved some aspects of ecosystem function and community structure (i.e., increased ecosystem respiration, ammonium uptake, and select macroinvertebrate metrics) but not others (i.e., no change in suspended solid concentrations, water quality indicators, and some measures of macroinvertebrates) (Table 1). Most ecosystem responses were likely the result of increased channel complexity and organic matter accumulation within debris dams. The organic matter accumulations may have transformed these locations into hotspots of biological activity and nutrient cycling. Low positive response of some ecosystem metrics to instream restoration may have been caused by high water years following restoration and short-term burial of debris dams associated with sediment movement within the channel. It is likely that the 3 -year postrestoration period was not sufficient to observe effects on slower-responding aspects of stream ecosystem function that may take longer to respond to restorations. For example, responses of water quality, biogeochemical processes, and macroinvertebrate and fish assemblages to restoration can range from months to decades depending on factors such as the type and level of restoration and site-specific characteristics (Friberg et al. 1998, Laasonen et al. 1998, Muotka et al. 2002, Meals et al. 2010, Hamilton 2012, Shirey et al. 2016). 

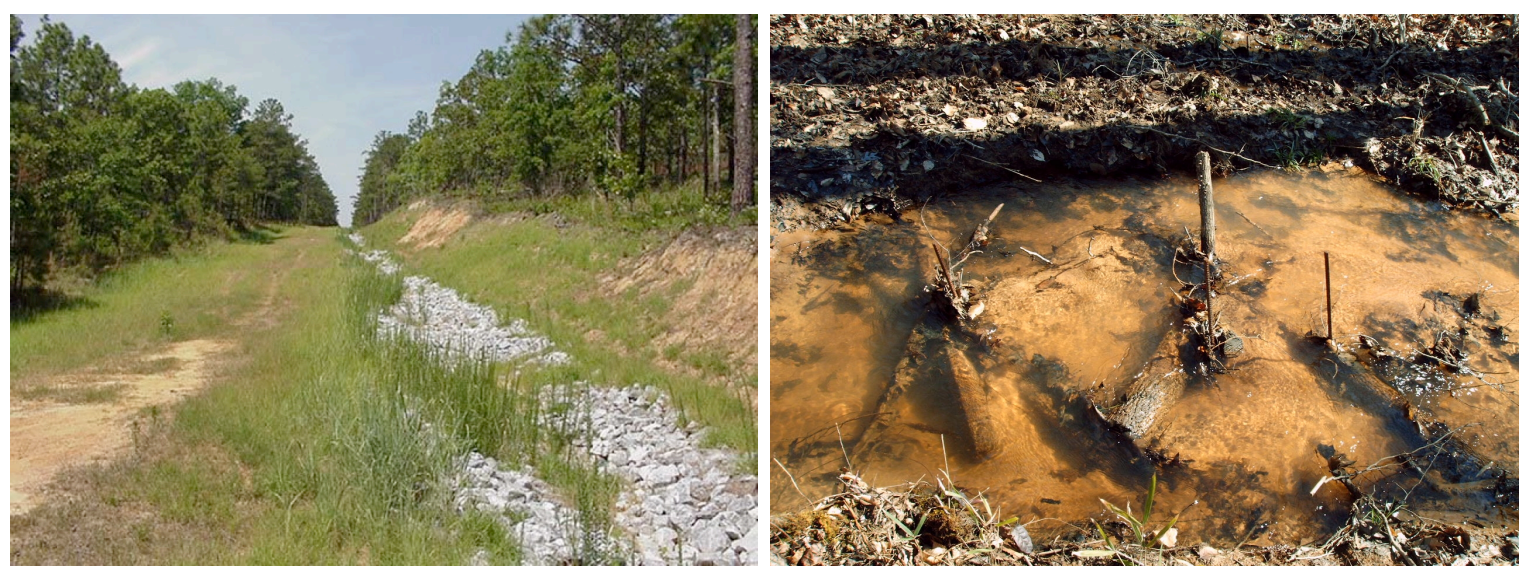

Figure 1 - Ephemeral drainage restoration (left) and instream woody debris addition restoration (right). Photos are from original project files.

Table 1 - Summary of initial (1-3 year) ecological responses to instream restoration relative to pre-treatment conditions (Mulholland et al. 2007), and predicted $\sim 14$ year restoration responses relative to pre-treatment conditions. Initial and predicted responses are illustrated as $\boldsymbol{\uparrow}$ (increase), $\Delta$ (change), or $\boldsymbol{\leftarrow} \rightarrow$ (no change).

\begin{tabular}{lcc}
\hline \multicolumn{1}{c}{ Indicator } & Initial response & Predicted response \\
\hline Water quality metrics & $\leftarrow \rightarrow$ & $\uparrow$ \\
Gross primary production & $\uparrow$ then $\leftarrow \rightarrow$ & $\uparrow$ \\
Ecosystem respiration & $\uparrow$ & $\uparrow$ \\
Ammonium uptake rate & $\uparrow$ & $\uparrow$ \\
Benthic particulate organic matter & $\uparrow$ & $\uparrow$ \\
Macroinvertebrate density & $\uparrow$ (seasonal) & $\uparrow$ \\
Macroinvertebrate richness & $\uparrow$ (seasonal) & $\uparrow$ \\
Macroinvertebrate structure & $\Delta$ (seasonal) & $\uparrow$ \\
\hline \hline
\end{tabular}

In the current study, our objective was to re-evaluate the effect of two restoration practices on stream ecosystem processes $\sim 14$ years after implementation.

The specific objectives were to:

1) determine if the improvements to ecosystem condition that were observed immediately (1-3 years) after restoration were:

a. still in an improved state $\sim 14$ years post-restoration, or

b. were no longer showing improvements (i.e., return to pre-treatment conditions).

2) determine if the ecosystem parameters that did not change immediately (1-3 years) after restoration have:

a) since responded to restoration, or

b) still showed no change with restoration. 
We hypothesized that if the instream restorations were still effective sites of organic matter accumulation (i.e., were not buried or dislodged during storms) and thus were still hotspots for biological activity, then the ecological metrics that did not change immediately with restoration would show improvements, whereas ecological metrics that improved with restoration would be at similar post-restoration levels (Table 1). We also hypothesized that if ephemeral restoration was still successful in reducing sedimentation rates, then stream water suspended solid concentrations would be lower and ecosystem metrics would improve (compared to pretreatment conditions and unrestored sites) because of a reduction in organic matter burial.

By re-assessing the effect of restoration on several stream ecosystem metrics, we provide necessary information on restoration efficacy and longevity, which is rarely assessed in the science of restoration ecology. These results can help inform whether these practices are worthwhile investments for future restoration of impaired watersheds at DoD installations. By evaluating the long-term effectiveness of restoration on stream ecosystem processes, our project addressed the Strategic Environmental Research and Development Program (SERDP) Statement of Need (SON) objective "to collect and analyze additional data associated with previously completed ecological studies whose ultimate tests of theory, treatment success, or management relevance require timeframes longer than the typical research project". Our research also addressed the four research needs outlined in the SON:

1. Testing initial hypotheses and conclusions: By examining the effectiveness of restoration technologies on stream ecosystem processes $\sim 14$ years after initial implementation, we reevaluated whether the initial conclusions on restoration efficacy still hold true.

2. Extending results from previous studies via statistical approaches: We evaluated ecosystem metrics measured in the original study for $\sim 1.5$ years and used the same (or very similar) methods and sampling frequencies to allow for a direct statistical comparison of the data. We included data from the original study as well as data collected in the $\sim 14$ year postrestoration assessment in the statistical analyses assessing the long-term efficacy of these restoration technologies.

3. Determine reduced-form datasets for effective and cost-efficient monitoring: Data from both the original study and the current study can help determine which ecosystem metrics (indicators) are most responsive to restoration in the short- and long-term and may be useful in future monitoring programs. Almost all of the indicators that were measured in this reevaluation are commonly measured in monitoring programs and are cost-effective.

4. Translate findings to DoD resource managers: We translated our findings on the long-term efficacy of these restoration technologies through presentations and webinars (https://www.serdp-estcp.org/Tools-and-Training/Webinar-Series/03-26-2020), publications (currently in preparation), interim and final SERDP reports, and an entry on the SERDPEnvironmental Security Technology Certification Program (ESTCP) Enviro Wiki (https://www.enviro.wiki/index.php?title=Stream_Restoration). The results from the current study and the original study can be used by land managers to assess whether these restorations are worthwhile investments on DoD lands. 


\section{BACKGROUND}

Headwater streams comprise over half of the stream and river miles on Earth (Downing et al. 2012, McManamay et al. 2017). Because headwater streams are intimately connected to the surrounding terrestrial environment, these systems are particularly susceptible to natural and anthropogenic impacts (e.g., Allan 2004, Maloney et al. 2005, Walsh et al. 2005, US EPA 2006). These perturbations can impair water quality, alter water quantity, degrade in-stream habitat, affect the quality and quantity of food resources for aquatic organisms, and impair freshwater biodiversity (NRC 1992). Headwater streams are also longitudinally connected to mainstem stream and river ecosystems, and thus effects on headwaters can have far-removed downstream impacts. For example, nitrate inputs to the headwaters of the Mississippi River contribute to the annual formation of the "dead zone" at the mouth of the Mississippi in the Gulf of Mexico (Rabalais et al. 2002). The lateral and longitudinal connection of headwater streams to other ecosystems highlights their vulnerabilities to degradation and the importance of minimizing perturbations to headwaters in order to preserve their ecosystem services on which humans and other organisms rely.

The US Environmental Protection Agency's (EPA) Biological Assessment estimates that approximately $42 \%$ of small streams in the US are in poor condition, $25 \%$ are in fair condition, and $28 \%$ are in good condition (US EPA 2006). As such, over $\$ 1$ billion is spent on stream restorations annually in the US (Bernhardt et al. 2005). Stream restoration is broadly defined as the process of returning the structural and functional properties of streams to pre-disturbance conditions (NRC 1992), with individual project goals typically being case-specific. The most common stream restoration goals are to: 1) improve water quality; 2) manage riparian zones; 3 ) improve in-stream habitat; 4) allow for fish passage; and 5) stabilize stream banks (Bernhardt et al. 2005). However, the efficacy of stream restorations is not well documented due to the paucity of post-restoration monitoring studies (Bond and Lake 2003, Roni et al. 2008, Bernhardt and Palmer 2011). For example, only $\sim 10 \%$ of stream restoration projects assess responses after implementation (Bernhardt et al. 2005), and very few of these examine long-term ( $>10$ year) effects of restoration technologies (Roni et al. 2008, Tullos et al. 2009).

Stream restoration techniques are wide-ranging, including the addition of structures to stabilize banks, physical modification of stream channels, reintroduction of native flora and fauna, installation of fish ladders, alteration of flow regimes, addition of in-stream structures (e.g., woody debris, boulders), and changes to land use and land cover (e.g., revegetation of stream banks and adjacent riparian zones, livestock exclusion) (NRC 1992, Bernhardt et al. 2005). Selecting appropriate restoration technique(s) for a specific location depends on a variety of factors, such as the type of predominant environmental stressor(s), the location of the stream within the watershed, and the watershed characteristics (e.g., land use, land cover) (NRC 1992, Bernhardt et al. 2005, Palmer et al. 2005). Many stream restorations focus on improving or modifying the stream itself, but because of the connectivity of streams to the surrounding watershed, it has been noted that improvements due to instream restorations may be minimal if larger-scale impacts (e.g., land disturbances) are not concurrently addressed (NRC 1992, Craig et al. 2008, Roni et al. 2008, Bernhardt and Palmer 2011). 
The addition of large wood (i.e., coarse woody debris [CWD]) to headwater streams is a commonly used and low-cost (i.e., median per project cost of $\$ 20,000$; Bernhardt et al. 2005) restoration technique. CWD additions typically are used to improve instream habitat, with numerous potential benefits including creating habitat for benthic macroinvertebrates and fish, providing colonization surfaces for microorganisms (e.g., algae, fungi, bacteria), increasing the retention of sediments, trapping organic matter (an important basal resource for some freshwater organisms), and altering the hydraulics and morphology of stream channels (Bilby and Likens 1980, Smock et al. 1989, Bilby and Ward 1991, Roberts et al. 2007a, Roni et al. 2015). While the potential benefits may be numerous, a lack of post-restoration monitoring has resulted in a limited ability to evaluate the efficacy of CWD additions as a restoration technique (Roni et al. 2002, Thompson 2005).

\subsection{MATERIAL AND METHODS}

\subsubsection{Study Sites}

The study was conducted at sites on FBMI that received considerable attention from previous SERDP projects focused on landscape disturbance effects on stream ecosystems and initial ecosystem responses to restoration activities (Houser et al. 2005, 2006, Maloney et al. 2005, 2006, 2008, Maloney and Feminella 2006, Mulholland et al. 2007, Roberts et al. 2007a, Figure 2). The FBMI is in the Southeastern Plains Level-III ecoregion (Omernik 1987) in west-central Georgia. This ecoregion, characterized by a mild, humid climate and year-round precipitation, is noted for streams with high-sediment loads and generally degraded from past and current land use. Further, the Southeastern Plains in general is considered a global biodiversity hotspot and particularly known for high endemism as well as a high rate of habitat loss (Noss et al. 2015). On FBMI, the predominant contemporary landscape disturbance derives from military training including dismounted infantry tactics, tracked vehicle maneuvers, heavy weapon use, and airborne training drop zones (USAIC 2001, Dale et al. 2002). Forestry practices at FBMI include selective timber harvesting and controlled burning, much of which is related to reestablishment of longleaf pine forests and red-cockaded woodpecker (Picoides borealis) populations (Noss 1989, Dale et al. 2002).

Five sites on FBMI were selected for restoration in 2003, with an additional three sites used as unrestored controls (Table 2). These sandy-bottom $1^{\text {st }}$ - and $2^{\text {nd }}$-order streams spanned a range of upland disturbance from relatively undisturbed to heavily disturbed (Maloney et al. 2005, Table 2). The study streams were generally low gradient with high riparian shading and characterized by a wide range of CWD abundance (from $\sim 3$ to $12 \%$ areal benthic coverage). Three sites (Bonham Creek [BC], Kings Mill Creek [KM1], and Sally Branch Trib. 2 [SB2]) received ephemeral drainage restoration, and four sites (Little Pine Knot Trib. [LPK], Sally Branch Trib. 3 [SB3], SB2, and KM1) received instream restoration. Both restoration technologies were implemented in two sites (KM1, SB2) (Table 2). Two sites served as unrestored controls (Hollis Branch [HB] and Sally Branch Trib. 4 [SB4]) (Table 2). A third unrestored control site was used in the original study (Bonham Creek 2), but the land surrounding this stream experienced significant disturbance with the construction of the Digital Multi-Purpose Range Complex in 2004 (Mulholland et al. 2009); therefore, this site was not used in the current study. 
Ephemeral drainage restoration involved closing point-source sediment inputs, re-contouring and stabilizing channel sideslopes, sowing Coastal Bermuda grass on exposed soil, and planting longleaf pine in 2004-2005. The instream habitat restoration involved the creation of artificial woody debris dams along 100-150 m stream reaches in 2003 and 2004. In August 2003, riparian trees (Nyssa sylvatica at KM1, SB2, and SB3 and Quercus alba at LPK) that were 10-20 cm in diameter were felled and then cut to lengths of 1-2 $\mathrm{m}$. The logs were left on the stream banks to dry for 2-3 months before the debris dams were constructed. Ten woody debris dams were installed $\sim 10 \mathrm{~m}$ apart in each restored reach. The individual debris dams consisted of $3 \operatorname{logs}$ placed in a Z-shaped pattern and anchored to the streambed using rebar. The logs did not span the entire stream width; therefore, this configuration allowed for water passage during baseflow and did not impound upstream reaches. High sedimentation rates led to near-complete burial of CWD dams at two sites (SB3 and LPK) within the first year, resulting in an additional installation of $10 \mathrm{CWD}$ dams in these two streams in November 2004. Additional details on these restoration techniques can be found in Mulholland et al. (2007) and Roberts et al. (2007a).

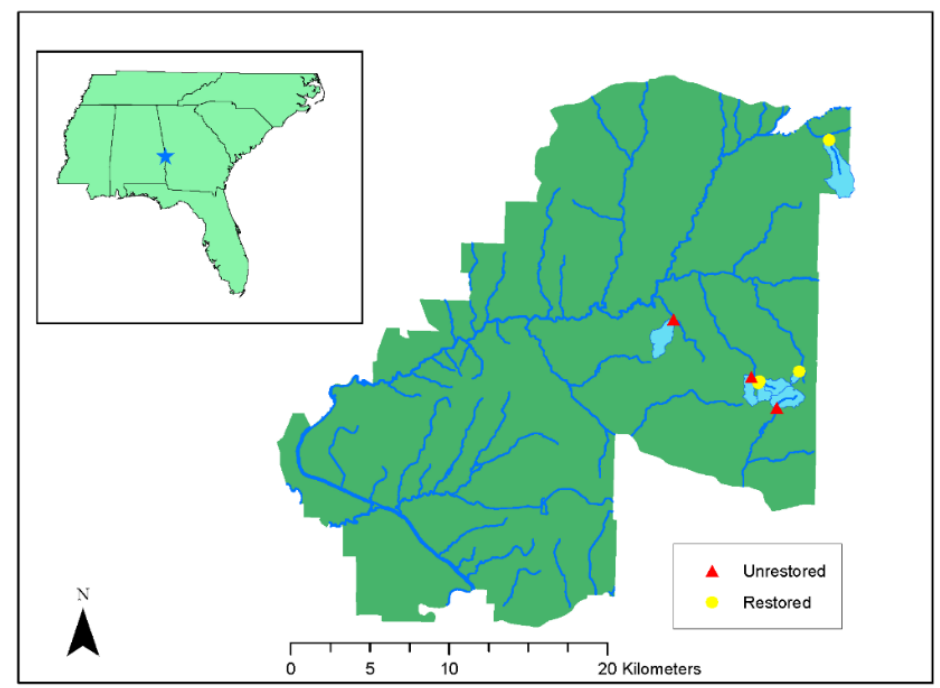

Figure 2 - Location of the seven study sites at Fort Benning Military Installation, Georgia. Sites that received instream restoration are shown in yellow circles, and sites that did not receive instream restoration are shown in red triangles. 
Table 2 - Descriptions of the 7 study sites and restoration types used in the current study (\% disturbance data are from Mulholland et al. [2007]).

\begin{tabular}{lllc}
\hline \multicolumn{1}{c}{ Site } & \multicolumn{1}{c}{ Restoration type } & \multicolumn{1}{c}{ Restoration date } & $\begin{array}{c}\text { \% } \\
\text { disturbance } \\
\text { in catchment }\end{array}$ \\
\hline $\begin{array}{l}\text { Hollis Branch } \\
\text { (HB) }\end{array}$ & Unrestored control & Not applicable & 6.62 \\
$\begin{array}{l}\text { Sally Branch Trib. 4 } \\
\text { (SB4) }\end{array}$ & Unrestored control & Not applicable & 13.65 \\
$\begin{array}{l}\text { Bonham Creek } \\
\text { (BC) }\end{array}$ & $\begin{array}{l}\text { Ephemeral \& unrestored } \\
\text { control (for instream) }\end{array}$ & Summer 2004 & 10.46 \\
$\begin{array}{l}\text { Sally Branch Trib. 3 } \\
\text { (SB3) }\end{array}$ & Instream & Autumn 2003 \& 2004 & 10.49 \\
$\begin{array}{l}\text { Little Pine Knot } \\
\text { (LPK) }\end{array}$ & Instream & Autumn 2003 \& 2004 & 11.26 \\
$\begin{array}{l}\text { Kings Mill Creek } \\
\text { (KM1) }\end{array}$ & Instream \& ephemeral & $\begin{array}{l}\text { Autumn 2003 (instream) } \\
\text { Sally Branch Trib. 2 } \\
\text { (SB2) }\end{array}$ & Instream \& ephemeral \\
\hline \hline
\end{tabular}

\subsubsection{Experimental Design}

To address our research objectives, we revisited 7 stream sites at FBMI and collected physical, chemical, and biological data on monthly or seasonal time scales from May 2017 to January 2019. We evaluated a subset of the environmental indicators measured in the original study, i.e., parameters that initially changed (objectives $1 \mathrm{a}, \mathrm{b}$ ) or did not change (objectives $2 \mathrm{a}, \mathrm{b}$ ) in response to restoration, with sampling methodologies and frequencies closely following those in the original study to allow for direct comparisons. Many of these indicators are commonly measured by land managers in ecosystem health assessments and when assessing restoration efficacy (Alexander et al. 1998, Barbour et al. 1999). We focused our efforts on quantifying instream responses to both ephemeral and instream restorations as any benefits observed from ephemeral restoration in the riparian zone (e.g., decreased sedimentation rate) would likely be observed instream (e.g., decreased suspended solid concentrations). Specifically, if there was a consistent effect of instream restoration on a given environmental metric, then we would examine whether this effect was stronger in streams that received both restorations. We collected field data from all restored and unrestored (control) sites used in the original study (except for the one unrestored control site which experienced significant watershed disturbance) following a beforeafter control-impact (BACI) experimental design approach (Stewart-Oaten et al. 1986). Each ecological measurement was compared before and after the restoration, with 'after' including measurements collected immediately after the restoration (original study) as well as $\sim 14$ years post-restoration (current study). 


\subsubsection{Environmental Measurements}

Coarse woody debris surveys: A modified transect method (Wallace and Benke 1984) was used to quantify CWD abundance in streams. All submerged and buried (top $10 \mathrm{~cm}$ of substrate) CWD $>2.5 \mathrm{~cm}$ in diameter along 15 cross-channel transects was counted and measured following Maloney et al. (2005) and Mulholland et al. (2007). Data were converted to planar area, divided by area sampled within each transect, and then converted to \% areal coverage of CWD (Maloney et al. 2005). CWD sampling was performed in one season (October/November 2018).

Water quality: We measured key water quality parameters $(\mathrm{pH}$, specific conductivity, and total suspended solid [TSS], dissolved organic carbon [DOC], nitrate-N, ammonium-N, and soluble reactive phosphorus-P [SRP] concentrations) from monthly grab samples collected during low flow conditions (when possible) using standard methods (APHA 2005). Dissolved inorganic nitrogen [DIN] concentration was calculated as the sum of nitrate-N and ammonium-N concentrations. Stream discharge and water temperature were measured each time water quality samples were collected. Water quality sampling began in May 2017 and occurred approximately monthly until January 2019. When possible, all 7 streams were sampled within a 7-day window. However, some stream sites were not accessible for multiple weeks due to military training activities at FBMI. Therefore, in some months, not all 7 streams were sampled, or sampling occurred over a span of $\sim 2$ weeks. A total of 12-15 water quality samples were collected from each stream site in the $14-y$ post-restoration period.

Ammonium uptake: Whole-stream ammonium uptake rate was measured seasonally using shortterm ammonium releases (with a conservative tracer, $\mathrm{NaCl}$, to account for dilution) (Tank et al. 2006); a standard method in the field of stream ecology. To measure nutrient uptake rate, a solution of $\mathrm{NH}_{4} \mathrm{Cl}$ and $\mathrm{NaCl}$ was dripped into each stream using a metering pump at a set injection rate, and water samples were collected at $\sim 4$ regularly spaced sampling points along each 60-100 m study reach. The decline (i.e., uptake) in ammonium concentration along the reach (from the injection point to the most downstream sampling site) relative to the change in the conservative tracer (measured as specific conductivity) was fit to a first-order decay function to calculate nutrient uptake length $\left(S_{W} ; \mathrm{m}\right)$, nutrient uptake velocity $\left(v_{f}, \mathrm{~mm} / \mathrm{s}\right)$, and areal uptake rate $\left(U ; \mathrm{mg} \mathrm{N} / \mathrm{m}^{2} / \mathrm{d}\right)$ (Stream Solute Workshop 1990, Tank et al. 2006). High nutrient demand in a stream is indicated by short nutrient uptake lengths, fast nutrient uptake velocities, and high areal uptake rates. Five seasonal samplings occurred over the course of our project (Summer 2017, Fall 2017, Spring 2018, Summer 2018, Fall 2018).

Whole-stream metabolism: Whole-stream metabolism was estimated seasonally based on observed characteristics of the daily dissolved oxygen (DO) profile (Wang et al. 2003, Mulholland et al. 2005). Previous work in these FBMI streams found that gross primary production (GPP) was correlated with the daily amplitude of the DO deficit and that ecosystem respiration (ER) was correlated with the maximum daily DO deficit, thus providing indicators of whole-stream metabolism (Mulholland et al. 2005). This technique is known as the "extreme value method" (Wang et al. 2003) and was used because of the very low rates of GPP in our study streams. Because of these low GPP rates, contemporary whole-stream metabolism models (e.g., Grace et al. 2015, Appling et al. 2018) were unable to provide accurate estimates of reaeration, GPP, and ER rates. 
DO concentration and temperature were measured at each site at 15-minute intervals using a dissolved oxygen and temperature sensor (PME, Inc., Vista, California). Following the same protocol as the original project (Mulholland et al. 2007), stream metabolism indicators were estimated only during baseflow conditions. Therefore, metabolism metrics were estimated for one to several days after sensor deployment, depending on flow conditions (i.e., metabolism was not estimated during or after a storm). If metabolism indicators were measured for multiple days in a row, the mean value across those multiple days was calculated and used in subsequent analyses. Metabolism measurements took place in five seasons in the 14-y post-restoration period (Summer 2017, Fall 2017, Spring 2018, Summer 2018, Fall 2018).

Benthic particulate organic matter (BPOM): BPOM was measured seasonally in restored and unrestored streams, and methods largely followed Maloney et al. (2005) and Mitchell (2009) so data collected across projects were comparable. We used sediment cores (steel pipe, area $=2.01$ $\mathrm{cm}^{2}$, depth $=10 \mathrm{~cm}$ ) to quantify BPOM at 5 transects per stream in each of 5 seasons, with six samples collected across each transect. Samples were oven-dried at $70{ }^{\circ} \mathrm{C}$ to a constant mass $(\geq$ $72 \mathrm{~h}$ ), weighed, ashed in a muffle furnace at $550{ }^{\circ} \mathrm{C}$ for $3 \mathrm{~h}$, cooled in a desiccator, and reweighed for ash free dry mass (AFDM) (Minshall 1996). Stream averages were reported as \% BPOM based on the ratio of organic matter mass to the total sample mass for each sample. Five seasonal samplings of BPOM (August 2017, November 2017, February 2018, April 2018, and September 2018) were represented as Summer1, Fall, Winter, Spring, and Summer2.

Macroinvertebrates: Benthic macroinvertebrates were sampled seasonally in unrestored and restored streams using quantitative Hester-Dendy (HD) multiplate samplers (Rinella and Feminella 2005). Twelve HDs per stream (total area $=1.12 \mathrm{~m}^{2}$ ) were deployed in run habitats on each sampling date and left for 8 weeks to facilitate macroinvertebrate colonization. Due to repeated issues gaining access to streams, HD incubation times were increased to 8 weeks, as opposed to 6 weeks in the original study. All HD deployments and retrievals occurred within a 2week timeframe to minimize temporal variation and any other variation due to small differences in colonization time. Macroinvertebrates were identified to the lowest possible taxonomic level, usually genus, using keys in Wiggins (1996), Epler (2001), Merritt et al. (2008), and Morse et al. (2017). For each stream, we quantified total macroinvertebrate density, Ephemeroptera, Plecoptera, and Trichoptera (EPT) taxa density, percent of assemblage as EPT, Shannon diversity $\left(H^{\prime}\right)$, and species richness as these were focal metrics in the original study (Mulholland et al. 2007). Notably, taxa resolution differed slightly between Mulholland et al. (2007) and the present study, with Chironomidae being identified to tribe in the present study as opposed to genus in the prior study. Any historical data potentially influenced by disparities in taxonomic resolution (i.e., diversity and richness) were re-calculated from the original database using the present-day coarser taxonomic resolution for valid comparison. Five seasonal sampling events occurred for benthic macroinvertebrates (HD retrievals in August 2017, November 2017, February 2018, April 2018, and September 2018). The spring (April 2018) sample lacked sufficient macroinvertebrate abundance for analyses. Most HDs were dislodged or buried, likely due to unusually high seasonal streamflows, thus this season was removed from statistical analysis; however available data were still shown in figures.

Disturbance calculations: The original project defined watershed disturbance as the percentage of bare ground on slopes greater than 5\% within a watershed summed with the percentage of watershed area covered by unpaved roads and trails (Maloney et al. 2005). Based on this 
definition, we quantified watershed disturbance for the 14-year post-restoration period using land-cover characteristics from the 2016 National Land Cover Dataset (NLCD, Yang et al. 2018), watershed boundaries as calculated using the StreamStats program (USGS 2016), and the ArcGIS extension Analytical Tools Interface for Landscape Assessment (Ebert and Wade 2004). We also calculated the change in land cover characteristics from the period of the original project to the period of the current project using the 2001 and 2016 NLCD datasets.

Statistical analyses: Multiple linear mixed-effects models (GLMM) were used to analyze ecosystem function, water quality, and biotic responses (macroinvertebrates and BPOM) to CWD additions. We also used GLMM to compare CWD standing stocks in restored and unrestored streams. For water quality and biotic data, fixed effects were treatment (restored, unrestored), periods of restoration (pre-restoration, immediately post-restoration, and 14-y post restoration), and season. Response variables were water quality parameters, ecosystem function parameters, and the aforementioned biotic metrics. The random effects of season were nested within period, which was nested within stream. For nutrient uptake and stream metabolism metrics, we analyzed each season individually using GLMM due to the effects of seasonality on these ecosystem processes that are observed in many streams (e.g., Hoellein et al. 2007, Roberts and Mulholland 2007, Roberts et al. 2007b, Griffiths et al. 2013). We calculated type-II Analysis of Variance (ANOVA) tables for each GLMM to understand how treatment, period, and season (water quality and biota only) affected the response variables. We estimated marginal means for each GLMM to better understand the differences between model factors. For water quality, ecosystem metrics, and biotic data, we also analyzed just the 14-y post restoration data with general linear models, with restoration type as a factor. Linear regressions were used to understand how watershed disturbance affected water quality and ecosystem functions. We did not include data from BC in these regression analyses because the floodplain in $\mathrm{BC}$ was flatter and broader than the other sites, which may have provided increased protection from disturbance in the uplands (Houser et al. 2005); BC was also excluded from similar regression analyses in the original study (Houser et al. 2005, Maloney et al. 2005, Roberts et al. 2007a). A Welch twosample t-test was used to test for differences between disturbance levels calculated in Maloney et al. (2005) and those calculated using the 2016 NLCD dataset. When necessary, data were transformed using natural log or square root functions to meet parametric assumptions. We defined significance as a $p$-value $\leq 0.05$, and marginal significance as a $p$-value $>0.05$ and $\leq 0.1$.

\subsection{RESULTS AND DISCUSSION}

\subsubsection{Visual Condition of Stream Restorations}

Between May 8 and May 16, 2017, the project team visited FBMI to locate the sites from the original project. All 7 stream reaches were located (Figure 3), and CWD dams in the restored sites were still visible and intact to various degrees (Figure 4). This suggests that the CWD dams can persist for over a decade after installation. 


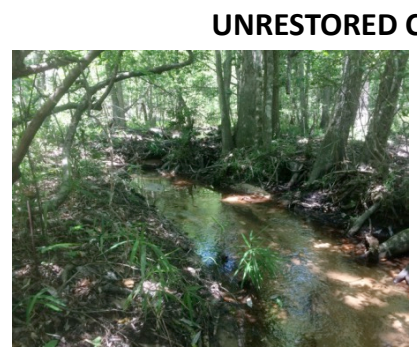

Hollis Branch

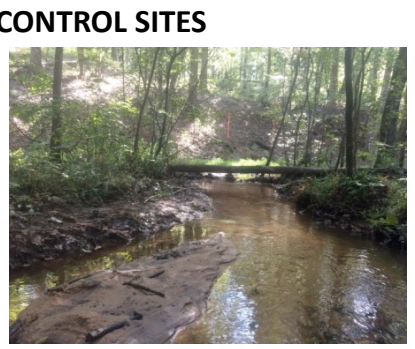

Sally Branch Trib. 4

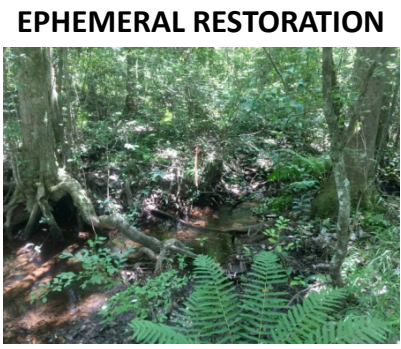

Bonham Creek Trib. 1

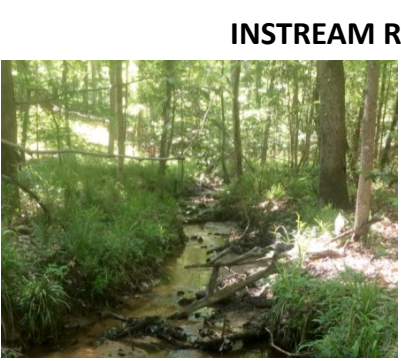

Sally Branch Trib. 3

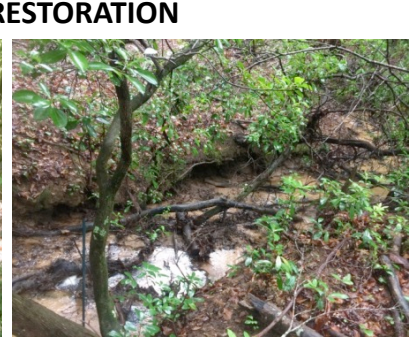

Little Pine Knot Trib.

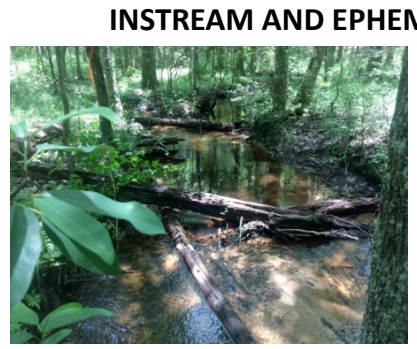

Kings Mill Creek

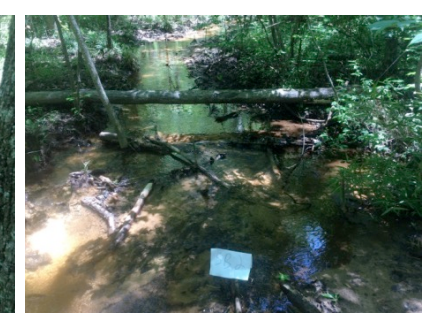

Sally Branch Trib. 2

Figure 3 - Photos of the 7 study streams, taken in May-June 2017. Coarse woody debris dams were visible in the four instream restoration sites (bottom row of photos).

\section{COARSE WOODY DEBRIS DAMS IN RESTORED STREAMS}

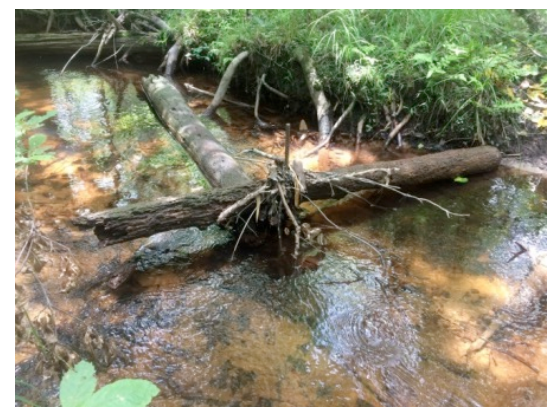

Kings Mill Creek

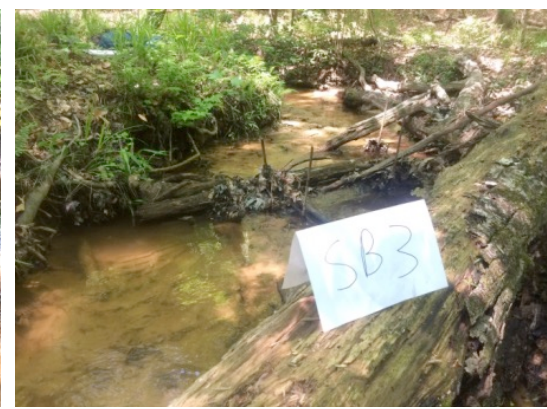

Sally Branch Trib. 3

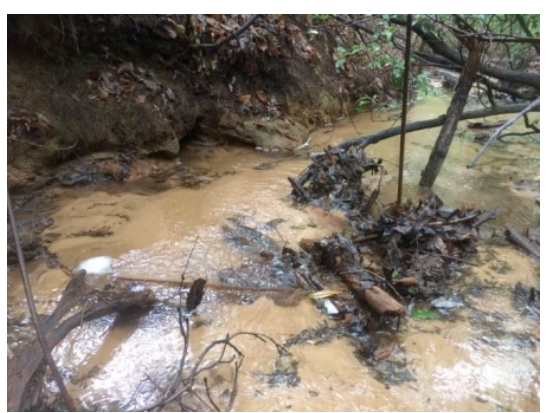

Little Pine Knot Trib.

Figure 4 - Close-up photos of debris dams in 3 of the 4 instream restored sites, taken in May-June 2017.

\subsubsection{Coarse Woody Debris}

CWD approximately doubled in restored streams immediately following the first addition of debris dams (Fall 2003) and tripled from the original amount after the second (supplemental) addition of debris dams (Fall 2004) (Mulholland et al. 2007). Although there was considerably greater CWD coverage in all stream systems in 2018 as compared to 2003-2006, \% cover of CWD was similar in unrestored and restored streams in 2018 (Figure 5). Specifically, streams $14-y$ post-restoration had significantly higher $\% \mathrm{CWD}$ than streams in the pre-restoration $(\mathrm{p}<$ $0.01)$ and immediately post-restoration $(\mathrm{p}<0.01)$ periods; however, $\% \mathrm{CWD}$ was similar in restored and unrestored streams in the $14-\mathrm{y}$ post-restoration period $(\mathrm{p}=0.50)$ (Figure 5$)$. 


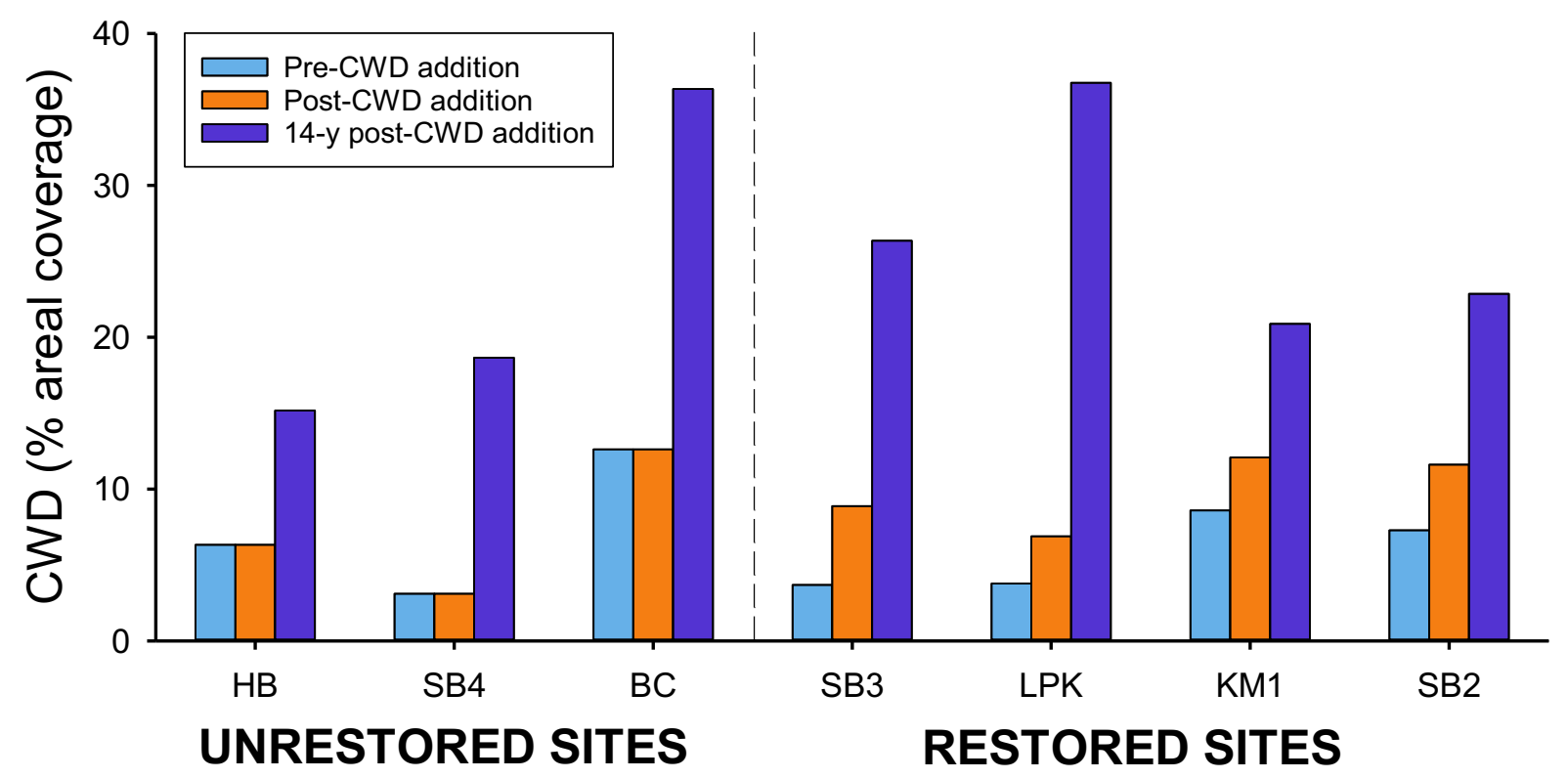

Figure 5 - Areal coverage (\%) of coarse woody debris (CWD) in stream beds in the three unrestored streams (HB, SB4, BC) and four restored streams (SB3, LPK, KM1, SB2) that received CWD additions (instream restorations) over time. CWD abundance is shown in the pre-restoration period (2001-2003; blue bars), immediately after restoration (2004-2007; orange bars), and 14 years post-restoration (2017-2018; purple bars).

\subsubsection{Water Quality}

The original project found no effect of instream restoration on water quality for the first 3 years after CWD additions (Mulholland et al. 2007). In the current project, we found no effect of CWD additions on water quality parameters when analyzing all three restoration periods together (all $\mathrm{p}$ $>0.2$ ) (Figures 6-8), but there were differences between restored and unrestored streams when analyzing only the 14-y post-restoration dataset (Appendix 1). Specifically, mean TSS concentrations were higher in restored vs. unrestored streams $(p=0.02$, Figure 6$)$ and mean DOC concentrations were higher during the winter in restored vs. unrestored streams $(p=0.02$, Figure 6).

We also observed differences between seasons and restoration periods for SRP concentrations, nitrate concentrations, ammonium concentrations, and $\mathrm{pH}$. For SRP and nitrate concentrations, we observed significant differences among seasons (SRP: ANOVA, $\mathrm{p}<0.01$, Wald Chi-square $=$ 16.3; nitrate: ANOVA, $\mathrm{p}=0.03$, Wald Chi-squared $=8.8$ ) and periods (SRP: ANOVA, $\mathrm{p}<0.01$, Wald Chi-squared $=12.8$; nitrate: ANOVA, $\mathrm{p}<0.01$, Wald Chi-squared $=12.36$ ). For ammonium concentrations, there were significant differences among seasons (ANOVA, $p<$ 0.01, Wald Chi-squared $=16.08$ ) and periods (ANOVA, $\mathrm{p}<0.01$, Wald Chi-squared $=12.9$ ), and significant interactions between treatment and period (ANOVA, $\mathrm{p}=0.01$, Wald Chi-squared $=$ 8.9). Lastly, for $\mathrm{pH}$, we found significant differences among seasons (ANOVA, $\mathrm{p}<0.01$, Wald Chi-squared $=34$ ) and periods (ANOVA, $p<0.01$, Wald Chi-squared $=61.6$ ), and significant interactions between treatment and period (ANOVA, $p<0.01$, Wald Chi-squared $=11.7$ ) and season and period (ANOVA, $\mathrm{p}<0.01$, Wald Chi-squared $=50.5$ ). While there was no overall 
effect of restoration on water quality metrics, these results highlight that water quality can vary seasonally and interannually in these streams at FBMI.

The original project found that there were strong stream-specific differences in water chemistry irrespective of restoration, and these stream-specific differences still held almost two decades later (in 2017-2018). For example, streams with low nitrate concentrations in the original project (2001-2006) still had low nitrate concentrations in 2017-2018 (Figure 8). This finding suggests that there were likely no significant impacts to the drivers of water chemistry (e.g., land use change) in these watersheds over the past two decades. 

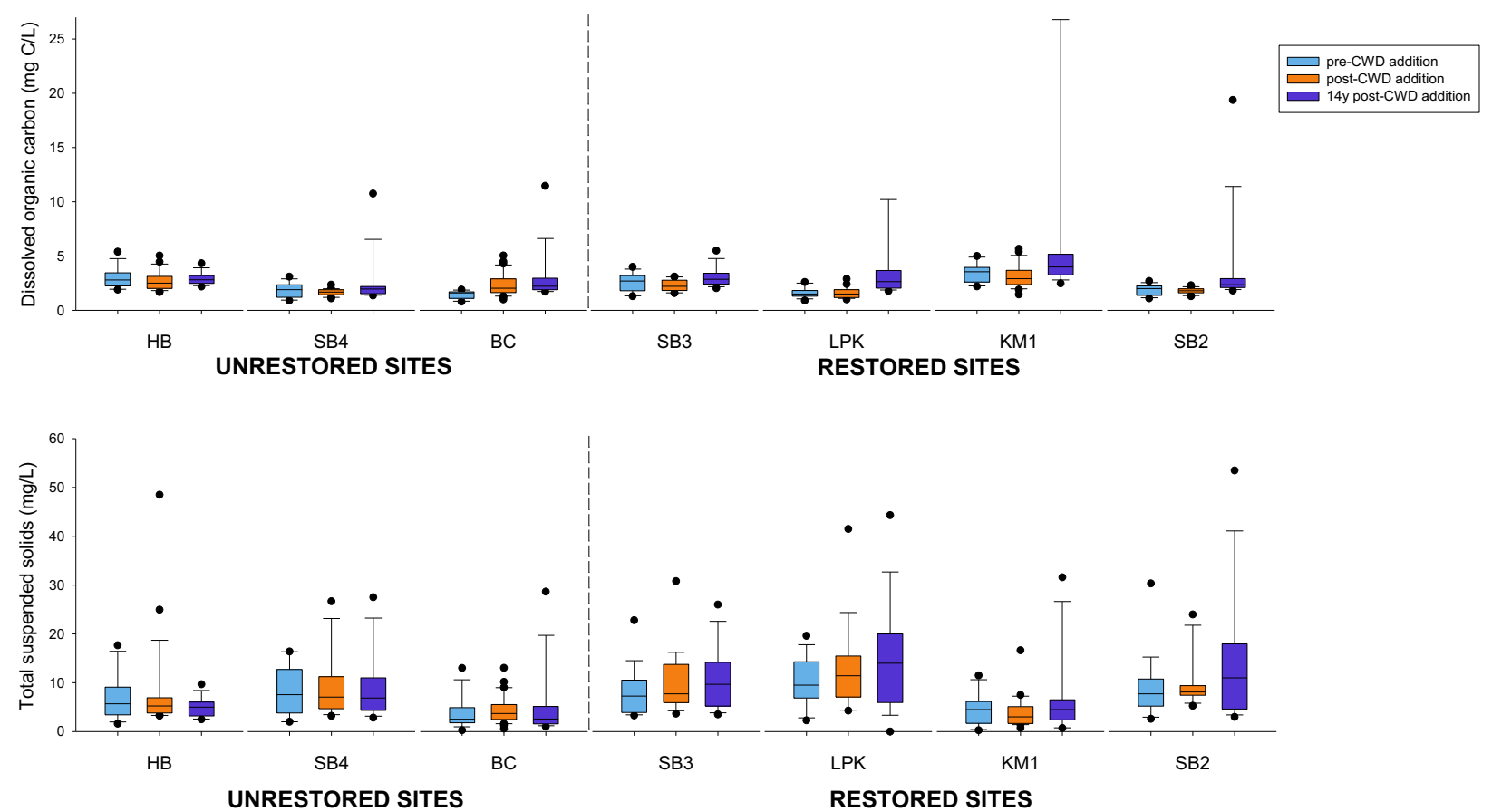

Figure 6 - Box plots summarizing dissolved organic carbon concentrations (DOC; mg C/L) [top panel] and total suspended solid concentrations (TSS; $\mathrm{mg} / \mathrm{L}$ ) [bottom panel] in stream water in the three unrestored streams $(\mathrm{HB}, \mathrm{SB} 4, \mathrm{BC})$ and four restored streams (SB3, LPK, KM1, SB2) that received instream coarse woody debris (CWD) additions. Data are shown for the pre-restoration period (2001-2003; blue boxes), immediately after restoration (2004-2007; orange boxes), and 14-y post-restoration (2017-2018; purple boxes). The line within the box plot represents the median value, the top and bottom of the box plots represent the $75^{\text {th }}$ and $25^{\text {th }}$ percentiles, respectively, the error bars represent the $10^{\text {th }}$ and $90^{\text {th }}$ percentiles, and the dots represent outliers. Data from the original project are from Mulholland et al. (2007). Two DOC outliers, one at LPK $(32 \mathrm{mg} / \mathrm{L})$ and the other at KM1 $(60.9 \mathrm{mg} / \mathrm{L})$, were not included in the figure. 


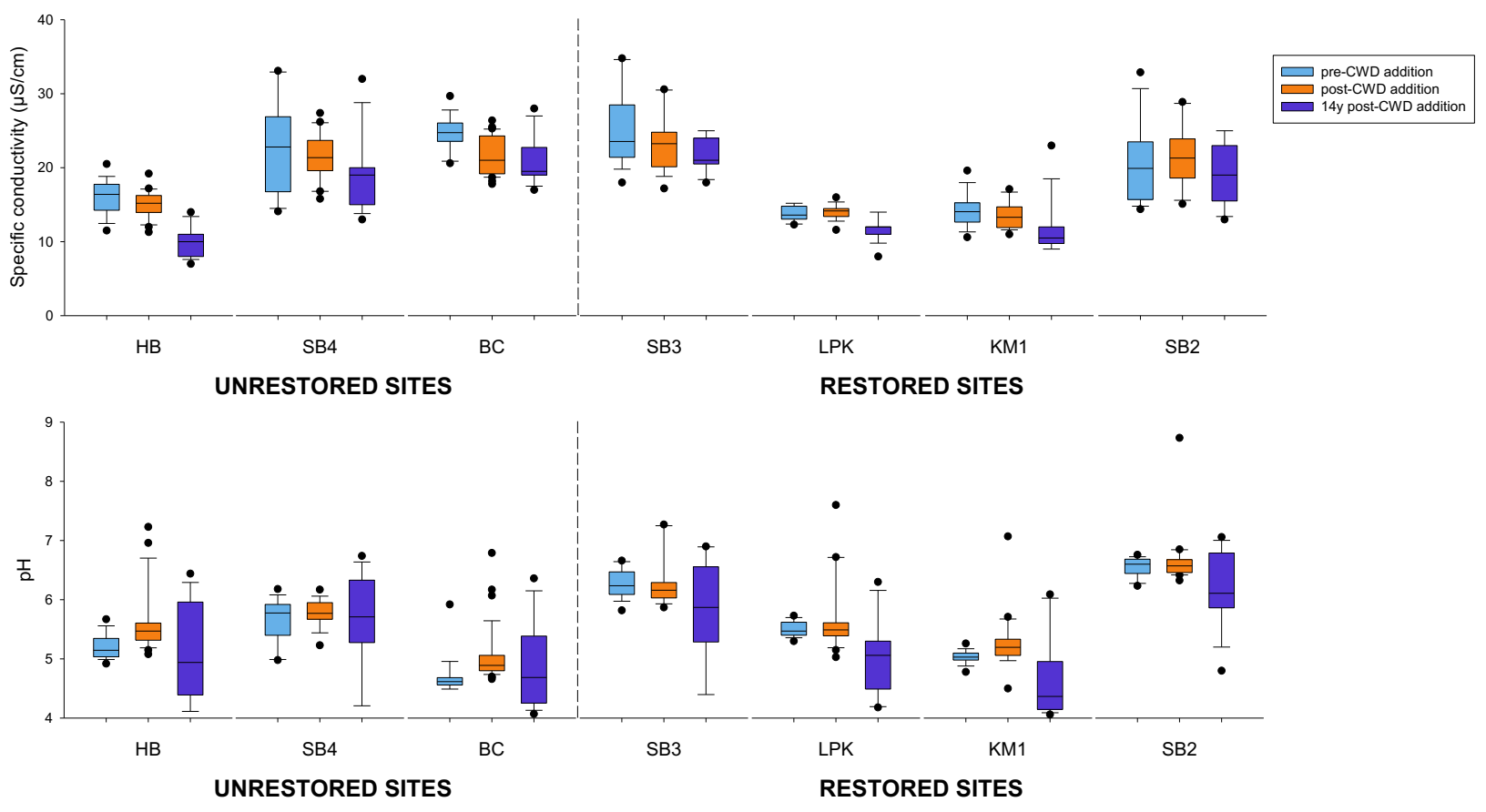

Figure 7 - Box plots summarizing specific conductivity $(\mu \mathrm{S} / \mathrm{cm})$ [top panel] and pH [bottom panel] of stream water in the three unrestored streams (HB, SB4, BC) and four restored streams (SB3, LPK, KM1, SB2) that received instream coarse woody debris (CWD) additions. Data are shown for the pre-restoration period (2001-2003; blue boxes), immediately after restoration (2004-2007; orange boxes), and 14-y post-restoration (2017-2018; purple boxes). The line within the box plot represents the median value, the top and bottom of the box plots represent the $75^{\text {th }}$ and $25^{\text {th }}$ percentiles, respectively, the error bars represent the $10^{\text {th }}$ and $90^{\text {th }}$ percentiles, and the dots represent outliers. Data from the original project are from Mulholland et al. (2007). 

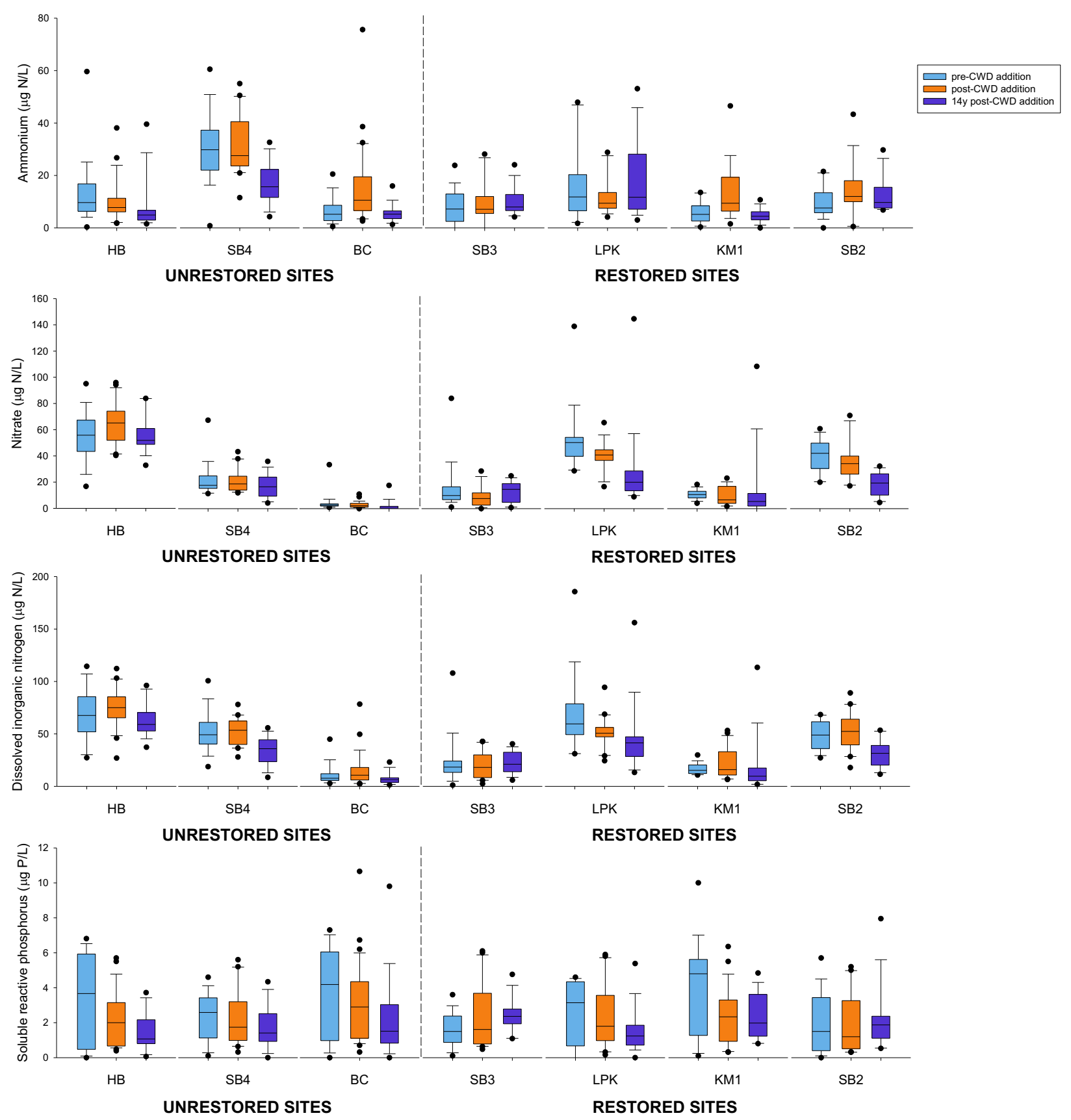

Figure 8- Box plots summarizing ammonium [top panel], nitrate [second panel], dissolved inorganic nitrogen [third panel], and soluble reactive phosphorus [bottom panel] concentrations ( $\mu \mathrm{g} N$ or $\mathrm{P} / \mathrm{L}$ ) in stream water in the three unrestored streams $(\mathrm{HB}, \mathrm{SB} 4$, BC) and four restored streams (SB3, LPK, KM1, SB2) that received instream coarse woody debris (CWD) additions. Data are shown for the pre-restoration period (2001-2003; blue boxes), immediately after restoration (2004-2007; orange boxes), and 14-y post-restoration (2017-2018; purple boxes). The line within the box plot represents the median value, the top and bottom of the box plots represent the $75^{\text {th }}$ and $25^{\text {th }}$ percentiles, respectively, the error bars represent the $10^{\text {th }}$ and $90^{\text {th }}$ percentiles, and the dots represent outliers. Data from the original project are from Mulholland et al. (2007). 


\subsubsection{Ammonium Uptake}

Ammonium uptake rates immediately following CWD additions increased in restored streams vs. unrestored streams (Roberts et al. 2007a), though these elevated areal uptake rates decreased over time (Figure 9). We found no long-term effect of CWD additions on areal ammonium uptake rates $(U)$ in the fall and summer when analyzing the entire dataset (original and current project data) (all $\mathrm{p}>0.14$ ), but a marginally significant effect during the spring (ANOVA, $p=$ 0.051, Wald Chi-squared $=3.8$ ). Opposite to our hypothesis of increased ammonium uptake rate with restoration, $U$ in spring was $23.4 \mathrm{mg} \mathrm{N} / \mathrm{m}^{2} / \mathrm{d}(\mathrm{SE}=14.3)$ lower in restored streams vs. unrestored streams during the 14-y post-restoration period and $16.1 \mathrm{mg} \mathrm{N} / \mathrm{m}^{2} / \mathrm{d}(\mathrm{SE}=14.3)$ lower in restored vs. unrestored streams during the post-restoration period. We found no longterm effect of CWD additions on ammonium uptake velocity $\left(v_{f}\right)$ in the summer or fall (all $\mathrm{p}>$ 0.2 ), but a significant effect during the spring (ANOVA, $p<0.01$, Wald Chi-squared $=7.0$ ) with uptake velocity in restored streams being $0.05 \mathrm{~mm} / \mathrm{s}(\mathrm{SE}=0.01)$ slower than in unrestored streams $(\mathrm{p}=0.02)$ in the $14-\mathrm{y}$ post-restoration period.

Among sites, ammonium uptake rates were variable (Figure 10, Appendix 2). Further, ammonium uptake rates have changed over the 14-year measurement period. Significant differences were observed across periods for $v_{f}$ in the fall (ANOVA, $\mathrm{p}=0.05$, Wald Chi-squared $=6.13)$, with a $v_{f}$ rate that was on average $0.02 \mathrm{~mm} / \mathrm{s}(\mathrm{SE}=0.007)$ higher in 14-y post-restoration streams than immediately post-restoration (marginally significant, $\mathrm{p}=0.07$ ). There was also a marginally significant difference in $v_{f}$ across periods in the spring (ANOVA, $\mathrm{p}=0.07$, Wald Chisquared $=3.3$ ). However, these periodically higher ammonium uptake rates were not consistent across all streams. For instance, $v_{f}$ was higher 14-y post-restoration than immediately after restoration in two of the four restored streams, but also higher 14-y post-restoration in two of the three unrestored streams (Figure 10). Also, in two of the four restored streams in the fall season, areal ammonium uptake rate $(U)$ was higher 14-y post-restoration than immediately after restoration.

There was a temporal pattern in ammonium uptake. Uptake rates increased in the restored streams immediately after the CWD addition in 2003 (Roberts et al. 2007a), and these uptake rates were the highest measured across both studies (Figure 9). Uptake rates were then lower for two years in all streams (2004-2005). This was followed by an increase in uptake rates in late 2005. Uptake rates measured during the current study (2017-2018) were similar to rates measured in 2004 and 2005 in all streams irrespective of restoration. 


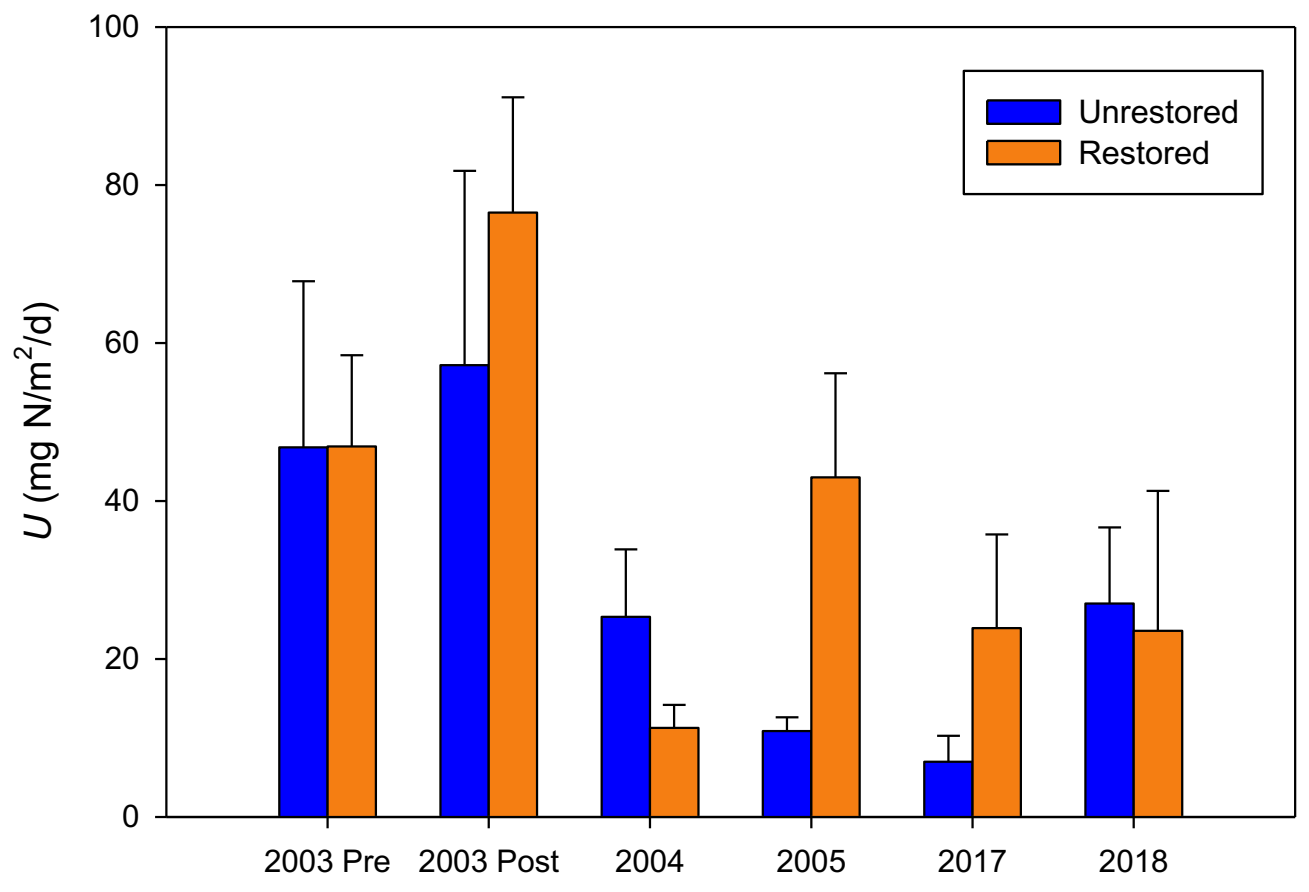

Figure 9 - Mean (+ standard error) areal uptake rates $\left(U ; \mathrm{mg} \mathrm{N} / \mathrm{m}^{2} / \mathrm{d}\right)$ of ammonium in fall immediately before (2003 pre) and after (2003 post) coarse woody debris (CWD) additions, and one (2004), two (2005), fourteen (2017), and fifteen (2018) years post-CWD additions in unrestored (blue) and restored (orange) streams. 

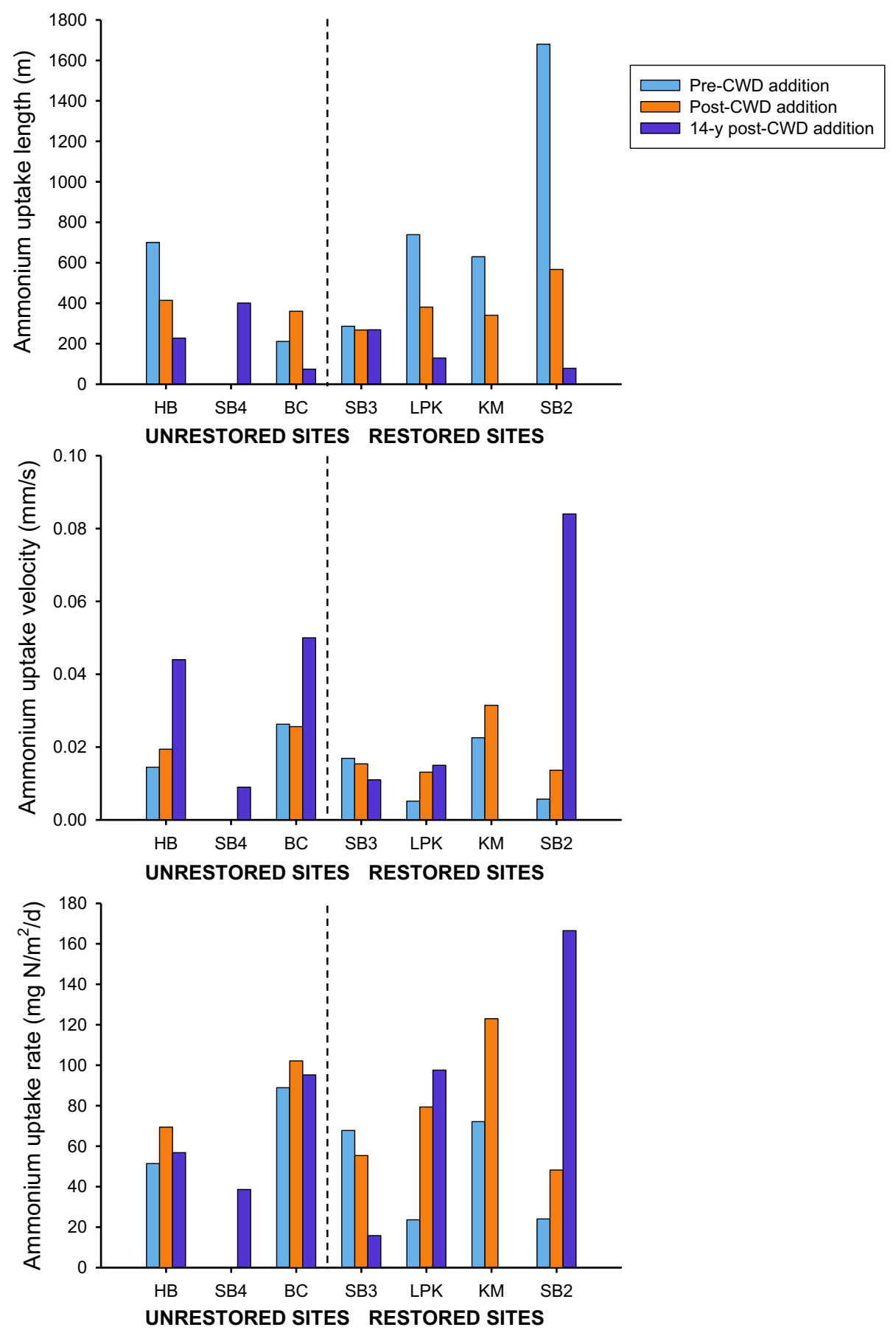

Figure 10 - Ammonium uptake length (m) [top panel], ammonium uptake velocity (mm/s) [middle panel], and ammonium uptake rate $\left(\mathrm{mg} \mathrm{N} / \mathrm{m}^{2} / \mathrm{d}\right)$ [bottom panel] in the three unrestored streams (HB, SB4, BC) and four restored streams (SB3, LPK, KM1, SB2) that received instream coarse woody debris (CWD) restorations. Data from the same season (fall/early winter) are shown for the pre-restoration period (immediately before restoration in October 2003; blue bars), immediately after restoration (2003-2005; orange bars), and 14-y postrestoration (2017-2018; purple bars). Ammonium uptake was not measurable in SB4 in October and November 2003, and in KM1 in November 2017 and December 2018. Data from the original project are from Roberts et al. (2007a) and Mulholland et al. (2007). 


\subsubsection{Whole-Stream Metabolism}

Immediately following the CWD additions in the fall of 2003, ER rates increased in restored sites (Roberts et al. 2007a), remained elevated for 1.5 years after restoration, and then decreased near the end of the 3-year measurement period (Mulholland et al. 2007). GPP rates were also elevated in restored vs. unrestored streams through spring 2005, after which there was no difference between treatments (Mulholland et al. 2007).

When we analyzed the full dataset (original and current project data) (Figure 11), we found no effect of CWD additions on the maximum daily DO deficit (an indicator of ER) during the spring (ANOVA, $p=0.64$, Wald chi-squared $=0.21$, Figure 12), summer (ANOVA, $p=0.16$, Wald chi-squared $=2.0$, Figure 13), or fall (ANOVA, $p=0.32$, Wald chi-squared $=1.0$, Figure 14). When analyzing just the 14-y post-restoration dataset (Appendix 3), there was also no effect of CWD additions on the maximum daily DO deficit (ER indicator) during the spring (ANOVA, $p$ $=0.42$, Wald chi-squared $=0.65)$, summer (ANOVA, $p=0.35$, Wald chi-squared $=0.89)$, or fall (ANOVA, $\mathrm{p}=0.45$, Wald chi-squared $=0.58$ ).

There was also no effect of CWD additions on the daily amplitude of the DO deficit (an indicator of GPP) during the spring (ANOVA, $p=0.71$, Wald chi-squared $=0.14$, Figure 12), summer (ANOVA, $p=0.82$, Wald chi-squared $=0.05$, Figure 13), or fall (ANOVA, $p=0.91$, Wald chisquared $=0.01$, Figure 14) when analyzing the full 14-y dataset (original and current project data) (Figure 11). When analyzing only the 14-y post-restoration dataset (Appendix 3), we also found no effect of restoration on the amplitude of the daily DO deficit (GPP indicator) during the spring (ANOVA, $\mathrm{p}=0.83$, Wald chi-squared $=0.05$ ), summer (ANOVA, $\mathrm{p}=1.0$, Wald chisquared $=0.0)$, or fall $($ ANOVA, $p=0.68$, Wald chi-squared $=0.17)$.

While there was no overall effect of CWD additions on whole-stream metabolism indicators, significant differences across restoration periods were observed for maximum daily DO deficit (ER indicator) in the spring (ANOVA, $\mathrm{p}=0.03$, Wald Chi-squared $=4.65$ ) and summer (ANOVA, $\mathrm{p}<0.01$, Wald Chi-squared $=9.0$ ). The maximum daily DO deficit in 14-y postrestoration restored streams was, on average, $0.51 \mathrm{mg} / \mathrm{L}(\mathrm{SE}=0.24)$ higher than pre-restoration restored streams during the spring (marginally significant, $\mathrm{p}=0.09)$ and $0.42 \mathrm{mg} / \mathrm{L}(\mathrm{SE}=0.18)$ higher than pre-restoration restored streams in the summer (marginally significant, $p=0.08$ ). The daily amplitude of the DO deficit (GPP indicator) (ANOVA, $p=0.03$, Wald Chi-square $=4.65$ ) also differed among restoration periods regardless of season and restoration treatment. The daily amplitude of the DO deficit for all streams in the 14-y post-restoration period, regardless of treatment, was $0.21 \mathrm{mg} / \mathrm{L}(\mathrm{SE}=0.1)$ lower than all pre-restoration streams, regardless of treatment (marginally significant, $\mathrm{p}=0.09$ ).

The mean value of the maximum daily DO deficit (ER indicator) across the entire 14-y dataset was $1.2 \mathrm{mg} / \mathrm{L}(\mathrm{SE}=0.09)$ in the fall, $1.07 \mathrm{mg} / \mathrm{L}(\mathrm{SE}=0.10)$ in the winter, $1.22 \mathrm{mg} / \mathrm{L}(\mathrm{SE}=$ $0.109)$ in the spring, and $1.10 \mathrm{mg} / \mathrm{L}(\mathrm{SE}=0.09)$ in the summer. There was no significant difference between seasons (all $\mathrm{p}>0.2$ ), even though we expect ER rates (and thus the maximum daily DO deficit) to be highest in the fall (Roberts et al. 2007b).

The mean value of the daily DO deficit amplitude (GPP indicator) was low across all seasons. Mean daily DO deficit amplitude across the entire $14-\mathrm{y}$ dataset was $0.44 \mathrm{mg} / \mathrm{L}(\mathrm{SE}=0.05)$ in the 
fall, $0.43 \mathrm{mg} / \mathrm{L}(\mathrm{SE}=0.06)$ in the winter, $0.46 \mathrm{mg} / \mathrm{L}(\mathrm{SE}=0.05)$ in the spring, and $0.40 \mathrm{mg} / \mathrm{L}$ $(\mathrm{SE}=0.05)$ in the summer. There was no statistically significant difference between any of the seasons (all $p>0.9$ ), even though we expect GPP rates (and thus the daily amplitude of the DO deficit) to be greatest in spring due to increases in water and air temperature, coupled with increased light intensity from the open riparian canopy prior to canopy closure (Roberts et al. 2007b).

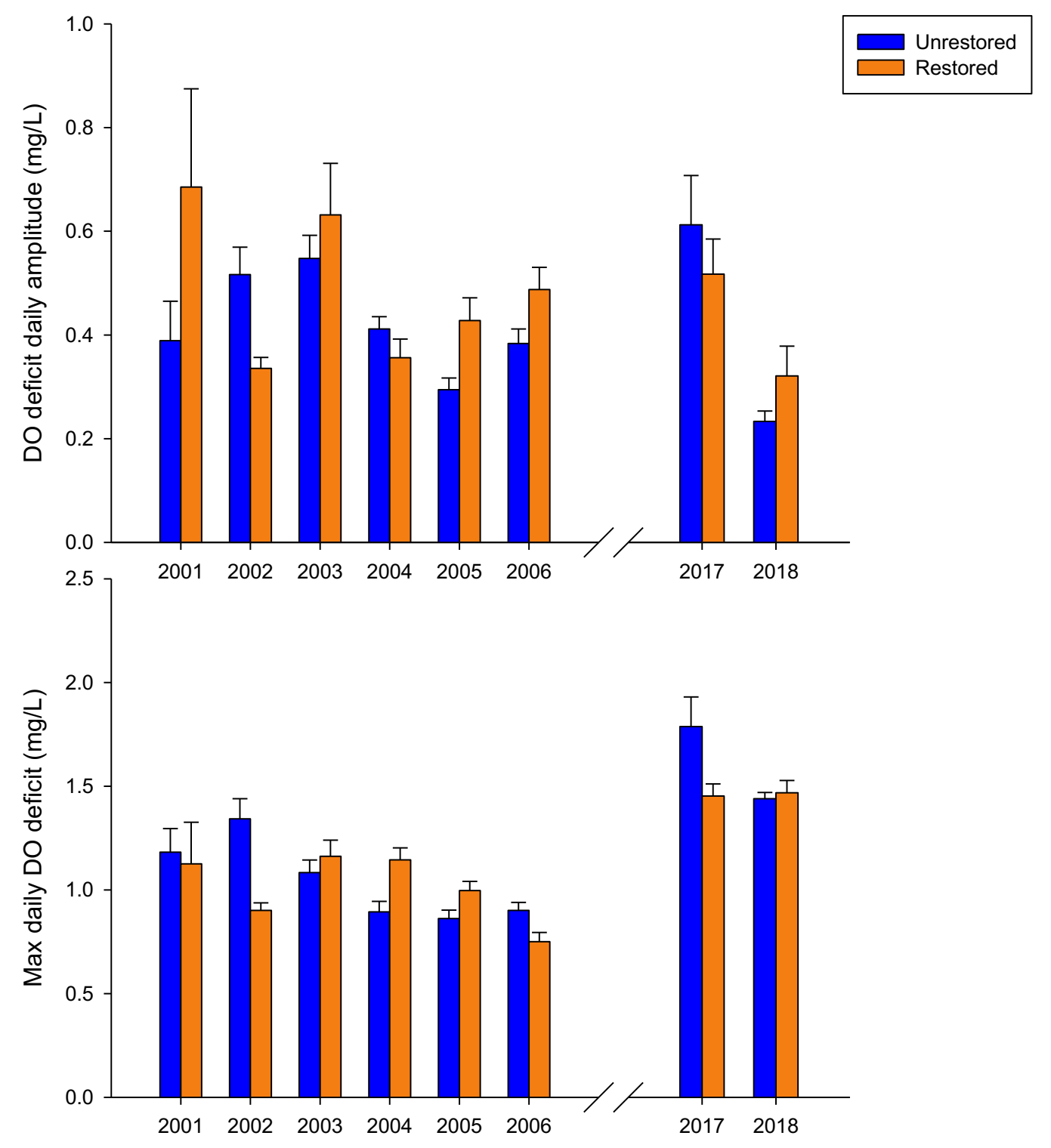

Figure 11 - Mean (+ standard error) whole-stream metabolism indicators, dissolved oxygen (DO) deficit daily amplitude ( $\mathrm{mg} / \mathrm{L})$ (an indicator of gross primary production) [top panel] and maximum daily DO deficit (mg/L) (an indicator of ecosystem respiration) [bottom panel], for all seasons across all years in unrestored (blue) and restored (orange) streams. 

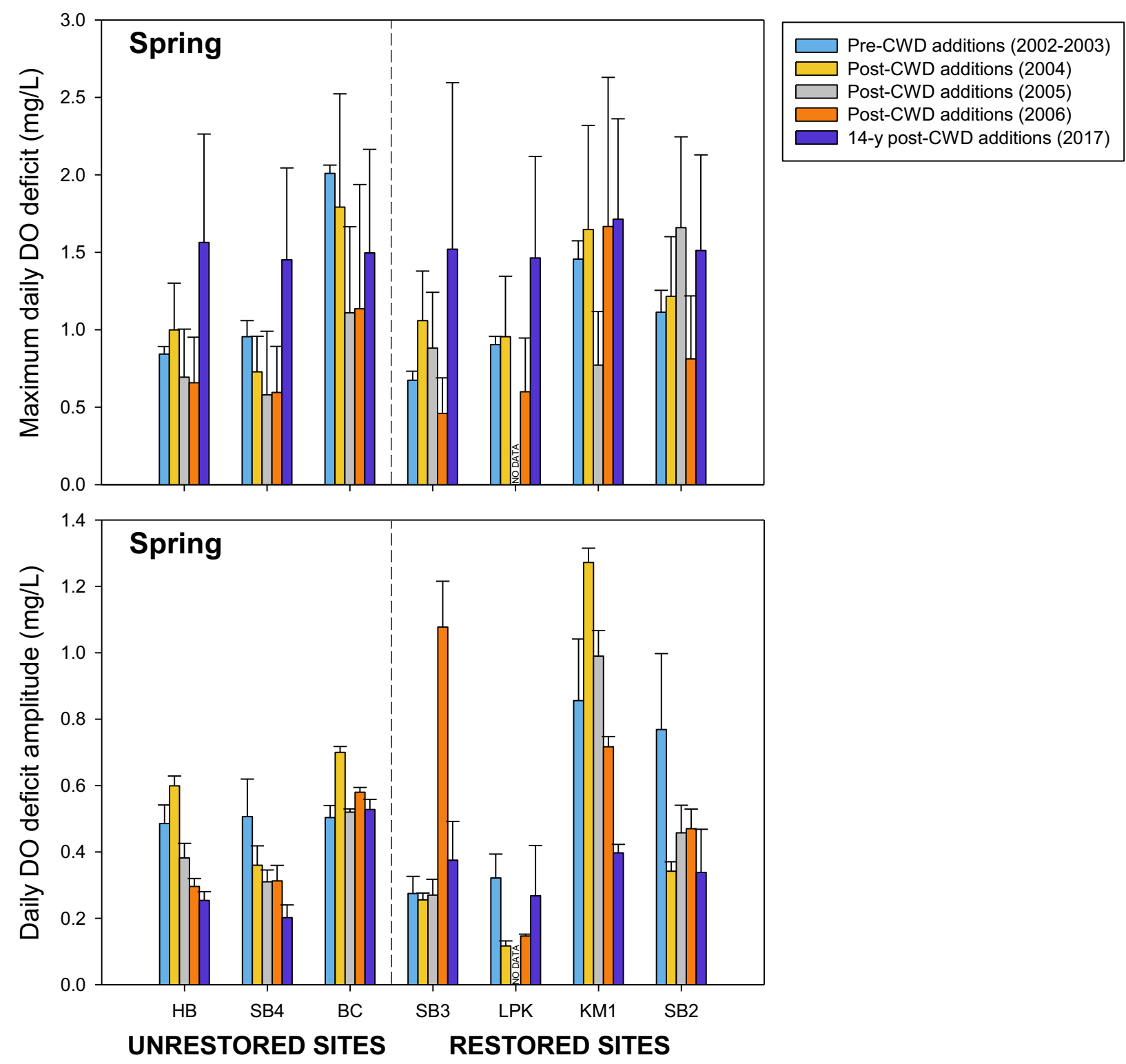

Figure 12 - Mean (+ standard error) maximum daily dissolved oxygen (DO) deficit (mg/L), an indicator of ecosystem respiration [top panel], and the daily amplitude of the DO deficit $(\mathrm{mg} / \mathrm{L})$, an indicator of gross primary production [bottom panel], in the three unrestored streams (HB, SB4, BC) and four restored streams (SB3, LPK, KM1, SB2) that received instream coarse woody debris (CWD) additions in spring across years. For each stream, the bars represent values prior to restoration (blue bar; 2001-2003), and post-restoration in 2004 (gold bar), 2005 (grey bar), 2006 (orange bar), and 2017 (violet bar; current project). Note that there are no measurements for LPK in spring 2005. Data from the original project are from Mulholland et al. (2007). 

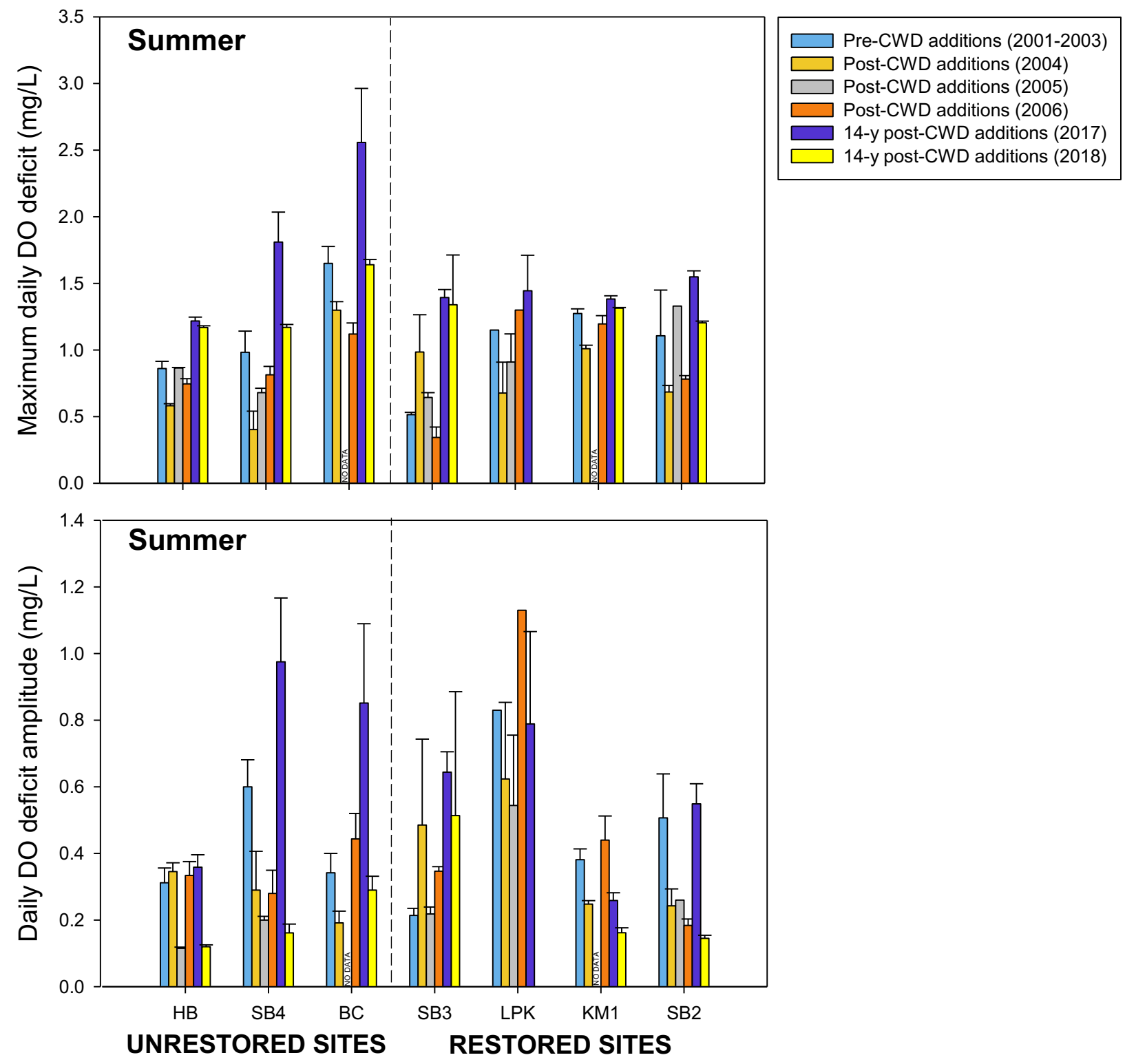

Figure 13 - Mean (+ standard error) maximum daily dissolved oxygen (DO) deficit (mg/L), an indicator of ecosystem respiration [top panel], and the daily amplitude of the DO deficit $(\mathrm{mg} / \mathrm{L})$, an indicator of gross primary production [bottom panel], in the three unrestored streams (HB, SB4, BC) and four restored streams (SB3, LPK, KM1, SB2) that received instream coarse woody debris (CWD) additions in summer across years. For each stream, the bars represent values prior to restoration (blue bar; 2001-2003), and post-restoration in 2004

(gold bar), 2005 (grey bar), 2006 (orange bar), 2017 (violet bar; current project), and 2018 (yellow bar; current project). Note that there are no measurements for BC and KM1 in summer 2005. Data from the original project are from Mulholland et al. (2007). 

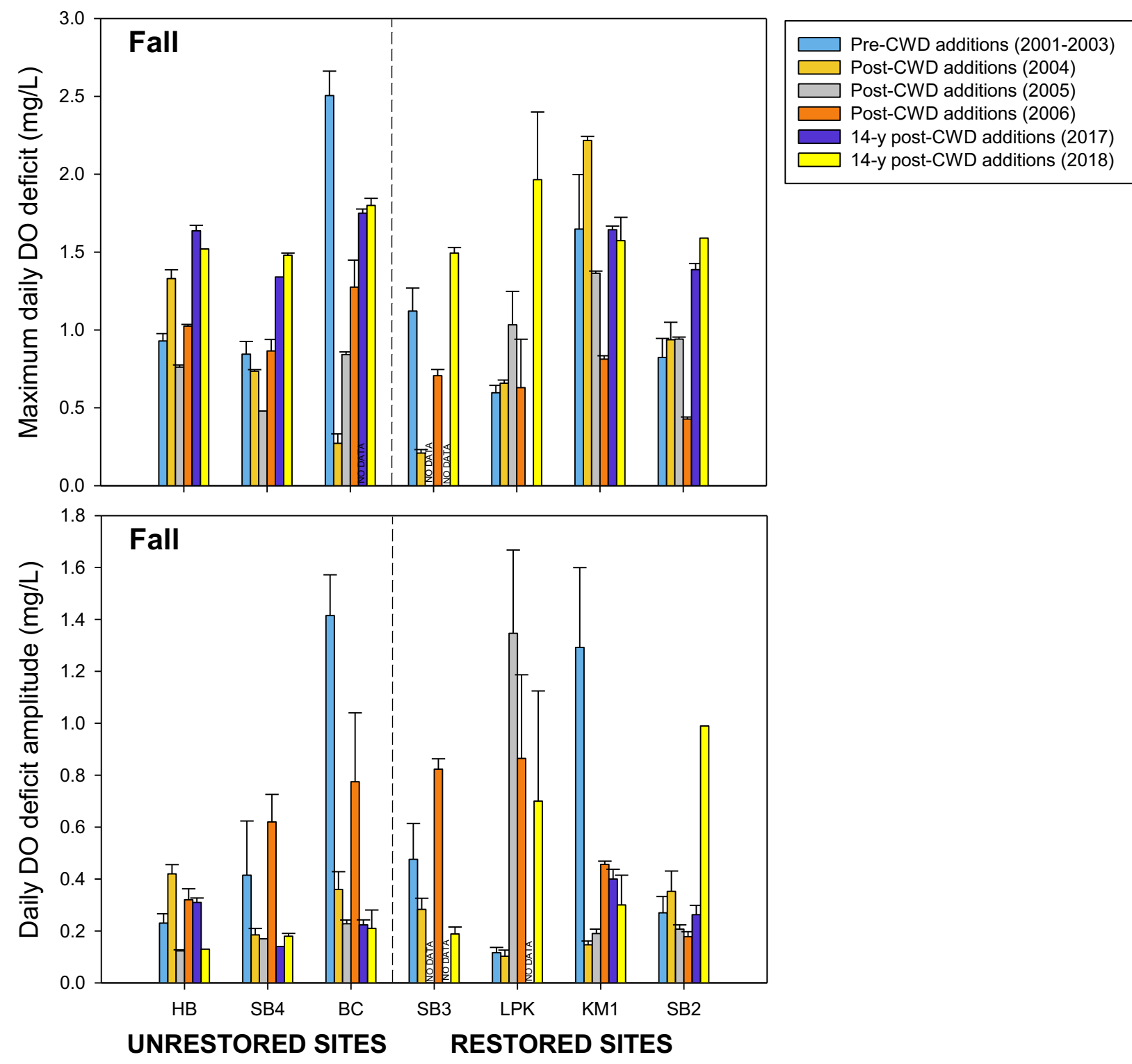

Figure 14 - Mean (+ standard error) maximum daily dissolved oxygen (DO) deficit (mg/L), an indicator of ecosystem respiration [top panel], and the daily amplitude of the DO deficit $(\mathrm{mg} / \mathrm{L})$, an indicator of gross primary production [bottom panel], in the three unrestored streams (HB, SB4, BC) and four restored streams (SB3, LPK, KM1, SB2) that received instream coarse woody debris (CWD) additions in fall across years. For each stream, the bars represent values prior to restoration (blue bar; 2001-2003), and post-restoration in 2004 (gold bar), 2005 (grey bar), 2006 (orange bar), 2017 (violet bar; current project), and 2018 (yellow bar; current project). Note that there are no measurements for SB3 in fall 2005 and 2017, and no measurements for LPK in fall 2017. Data from the original project are from Mulholland et al. (2007). 


\subsubsection{Benthic Particulate Organic Matter}

Mean BPOM values between restored and unrestored streams across all time periods showed a strong increasing period effect $(p=0.0005)$ and season effect $(p=0.039)$ but no treatment effect $(\mathrm{p}=0.39)$. Overall \%BPOM was higher 14-y post-restoration as opposed to pre- and postrestoration (Figure 15). When analyzing the 14-y post-restoration data only, linear mixed effects models revealed a significant seasonal effect $(\mathrm{p}=0.02$, Figure 16) but no treatment effect $(\mathrm{p}=$ 0.43 , Figure 16).

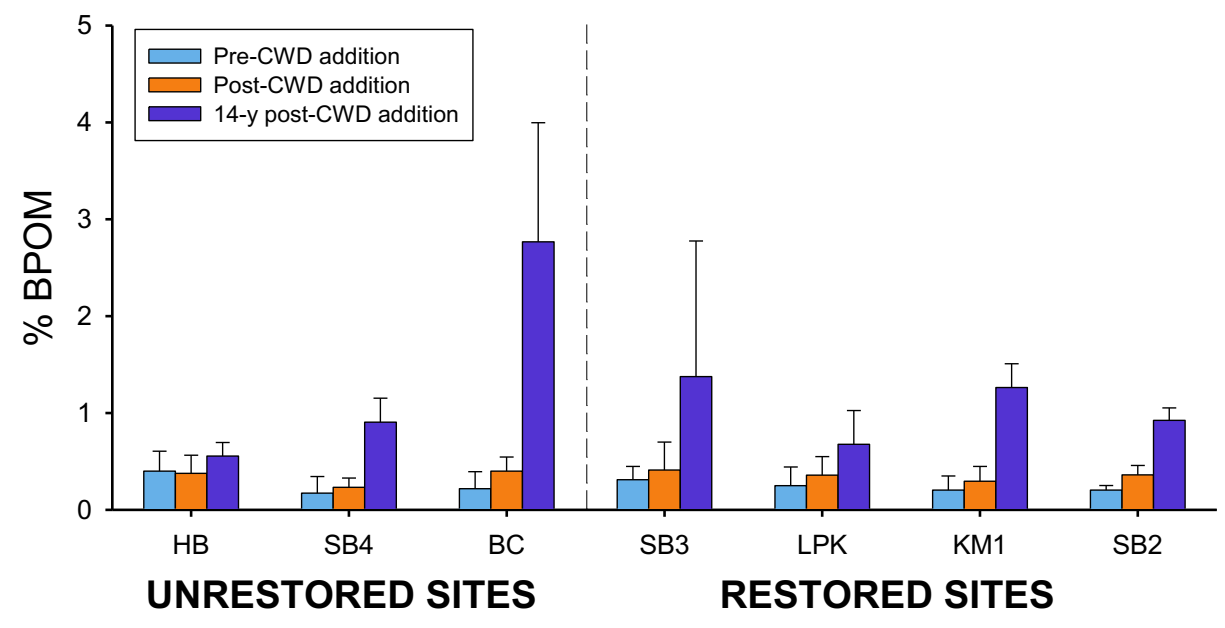

Figure 15 - Mean (+ standard deviation) percent of stream sediments as benthic particulate organic matter $(\% \mathrm{BPOM})$ in unrestored $(\mathrm{HB}, \mathrm{SB} 4, \mathrm{BC})$ and restored $(\mathrm{SB3}, \mathrm{LPK}, \mathrm{KM} 1$,

SB2) streams in the pre-restoration period (2001-2002; blue bars), immediately after restoration (2004-2007; orange bars), and 14-y post-restoration (2017-2018; purple bars). Data are stream averages across all seasons. Data from the original project are from Mulholland et al. (2007).

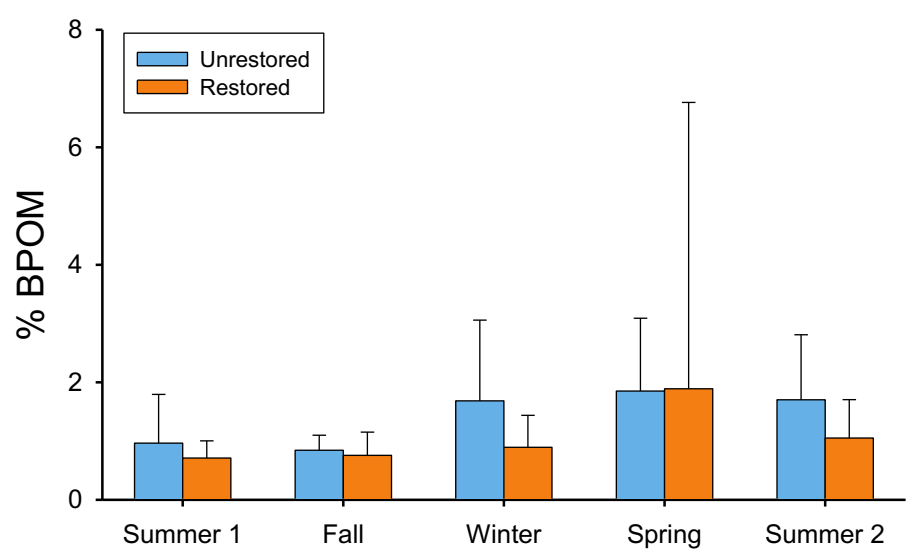

Figure 16 - Mean (+ standard deviation) percent of stream sediments as benthic particulate organic matter (\%BPOM) in unrestored (blue) and restored (orange) streams in each of 5 sampling seasons (August 2017 [Summer1], November 2017 [Fall], February 2018 [Winter], April 2018 [Spring], and September 2018 [Summer2]) in the 14-y postrestoration period. 


\subsubsection{Stream Macroinvertebrates}

There was considerable variation among the streams in terms of macroinvertebrate responses. The density of Ephemeroptera, Plecoptera, and Trichoptera $\left(\mathrm{EPT} / \mathrm{m}^{2}\right)$ ranged from 37.5 to 1460.7 $\mathrm{EPT} / \mathrm{m}^{2}$ in restored steams and 22.5 to $824.0 \mathrm{EPT} / \mathrm{m}^{2}$ in unrestored streams (Figure 17). Linear mixed effect models suggest that 14-y post-restoration EPT densities were not significantly different between restored and unrestored sites $(\mathrm{p}=0.42)$ but there was a significant season effect $(p=0.047)$ (Figure 17). Mean EPT density values between restored and unrestored streams across all time periods and seasons also revealed a strong season effect $(p=0.0004)$ and no treatment effect $(p=0.91)$ or period effect $(p=0.33)$ (Figure 18). For percentage of the macroinvertebrate assemblage as EPT (\%EPT), restored streams ranged from $0.50-19.46 \%$ EPT while unrestored streams ranged from $0.00-12.35 \%$ EPT (Figure 19). Similar to EPT density, 14y post-restoration $\%$ EPT was not significantly different between restored and unrestored streams $(\mathrm{p}=0.72)$ but there was a strong seasonal effect $(\mathrm{p}<0.001)$ (Figure 19). Mean \%EPT between restored and unrestored streams across all time periods and seasons revealed no treatment effect $(\mathrm{p}=0.68)$ but strong period $(\mathrm{p}<0.001)$ and season $(\mathrm{p}<0.001)$ effects (Figure 20).

Total macroinvertebrate density was variable across all streams with no discernible difference between unrestored and restored streams (Figure 21). Linear mixed effect models of 14-y postrestoration data revealed no significant treatment $(p=0.51)$ or season $(p=0.35)$ effect on total macroinvertebrate density (Figure 21). The total number of individuals in the study streams 14-y post-restoration was within the range of the previous measurement periods (Figure 22). Analysis of macroinvertebrate density between restored and unrestored streams across all time periods and seasons revealed a marginally significant treatment effect $(p=0.07)$ and strong period $(p<$ $0.001)$ and seasonal $(\mathrm{p}<0.001)$ effects (Figure 22). When averaged across all seasons and periods, macroinvertebrate densities were slightly higher in restored $\left(1154\right.$ individuals $\left./ \mathrm{m}^{2}\right)$ than unrestored $\left(1026\right.$ individuals $\left./ \mathrm{m}^{2}\right)$ streams. This marginal difference in macroinvertebrate density was observed primarily in the winter when comparing among all time periods.

Taxonomic richness and diversity metrics of macroinvertebrates were equivocal across restoration treatments. Taxa richness (number of genera, except Tribe for Chironomidae) ranged from 7 to 42 in the study streams, excluding several 0 occurrences in spring (see Appendix 4 for full taxa list). There was no effect of restoration on taxa richness 14 -y post-restoration $(p=0.16)$; however, there was a strong seasonal effect $(\mathrm{p}<0.001)$ (Figure 23). This seasonal effect generally reflected the reduced catch associated with Spring and to a lesser extent Summer2 (Figure 23). Analysis of all data (pre-, post-, 14-y post-restoration) together revealed no treatment effect $(\mathrm{p}=0.30)$ but significant period $(\mathrm{p}=0.01)$ and season $(\mathrm{p}<0.001)$ effects (Figure 24). Similarly, species diversity (Shannon's $H^{\prime}$ ) was not different between restored and unrestored streams in the 14-y post-restoration period $(\mathrm{p}=0.43)$; however, there was a significant season effect $(p=0.04)$ (Figure 25$)$. Analysis of macroinvertebrate diversity between restored and unrestored streams across all time periods and seasons revealed no treatment effect $(p=0.97)$ and no season effect $(p=0.91)$ but a significant period effect $(p=0.003)$ (Figure 26). 


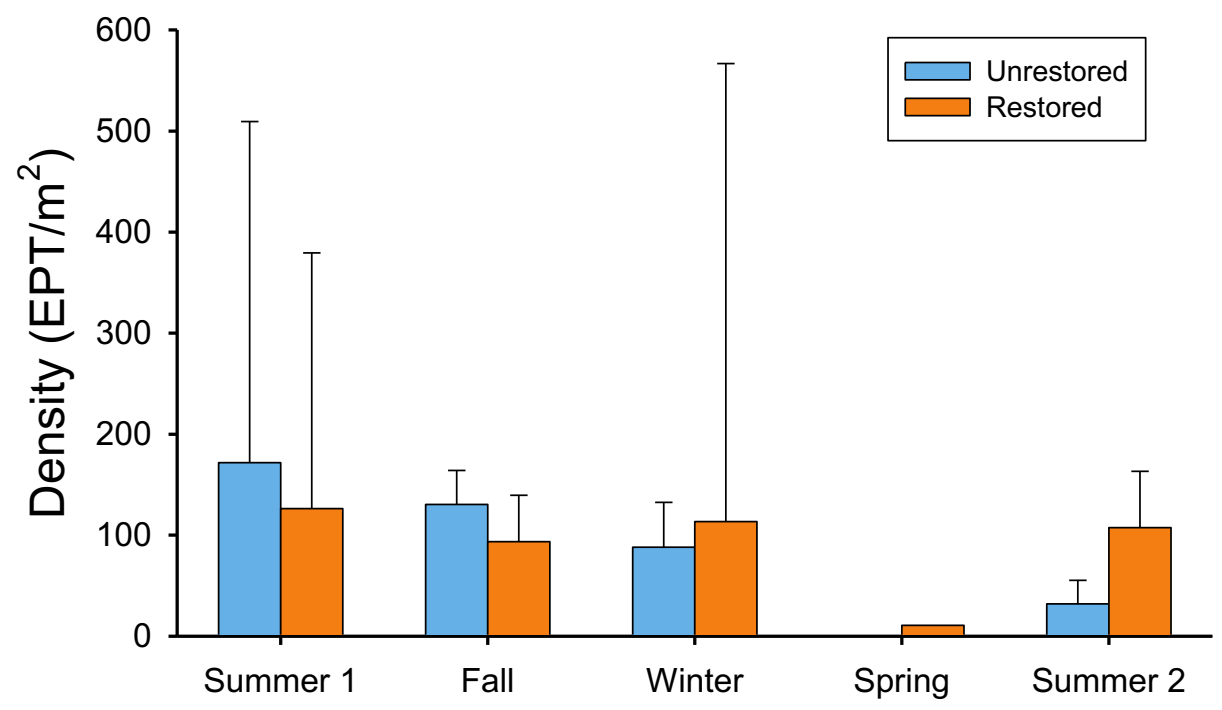

Figure 17 - Mean (+ standard deviation) Ephemeroptera, Plecoptera, and Trichoptera density $\left(\mathrm{EPT} / \mathrm{m}^{2}\right)$ in unrestored (blue) and restored (orange) streams in each of 5 sampling seasons (August 2017 [Summer1], November 2017 [Fall], February 2018 [Winter], April 2018 [Spring], and September 2018 [Summer2]) in the 14-y post-restoration period.

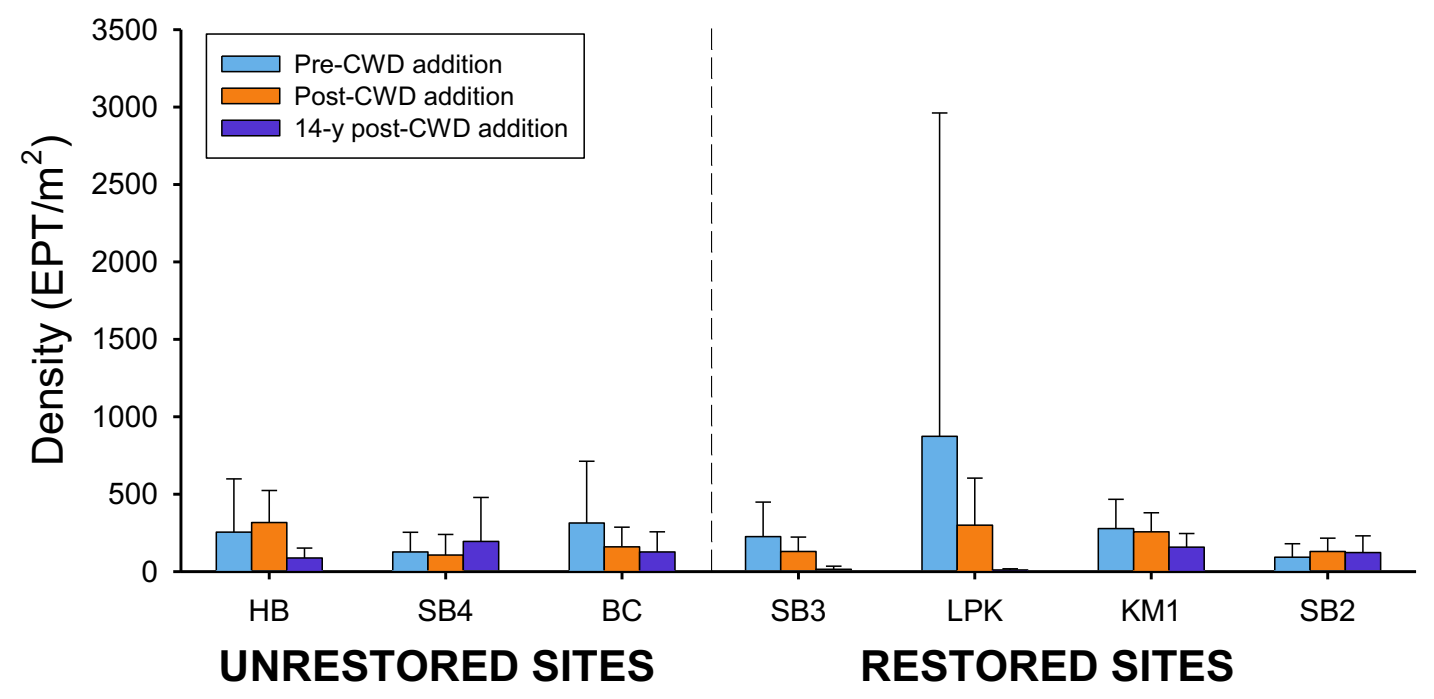

Figure 18 - Mean (+ standard deviation) Ephemeroptera, Plecoptera, and Trichoptera density $\left(\mathrm{EPT} / \mathrm{m}^{2}\right)$ in unrestored (HB, SB4, BC) and restored (SB3, LPK, KM1, SB2) streams in the pre-restoration period (2001-2003; blue bars), immediately after restoration (2004-2006; orange bars), and 14-y post-restoration (2017-2018; purple bars). Data are stream averages across all seasons. Data from the original project are from Mulholland et al. (2007). 


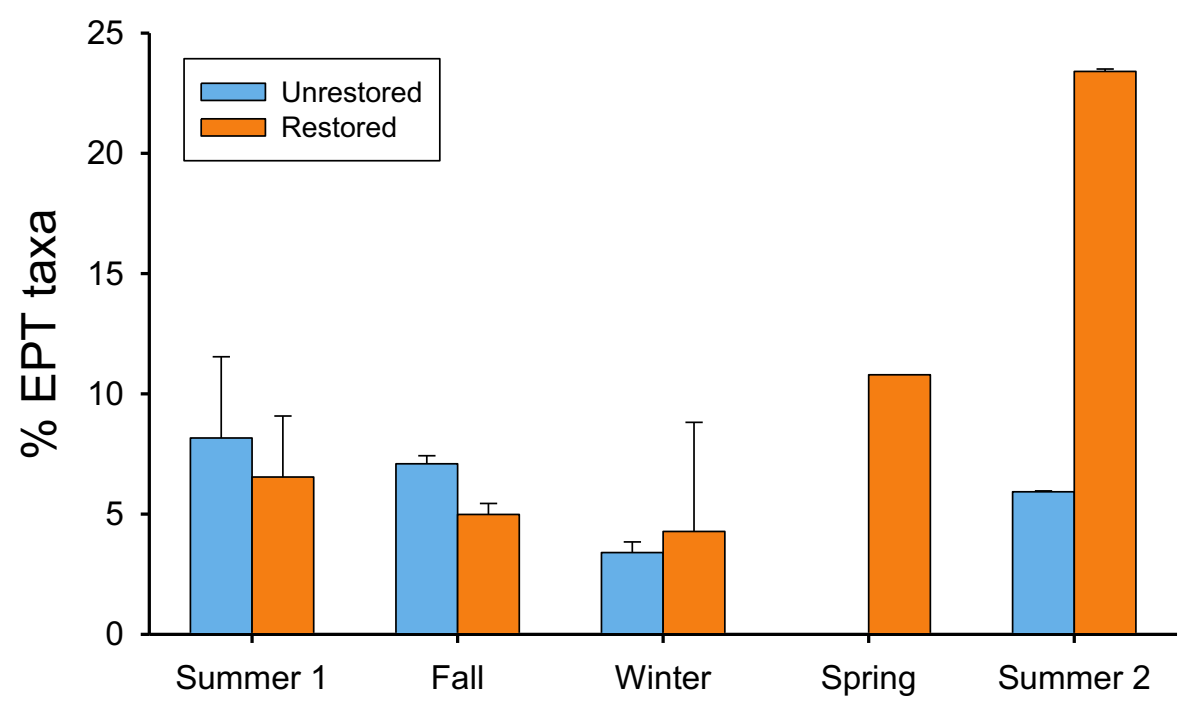

Figure 19 - Mean (+ standard deviation) percentage of Ephemeroptera, Plecoptera, and Trichoptera taxa (\%EPT) in unrestored (blue) and restored (orange) streams in each of 5 sampling seasons (August 2017 [Summer1], November 2017 [Fall], February 2018 [Winter], April 2018 [Spring], and September 2018 [Summer2]) in the 14-y postrestoration period.

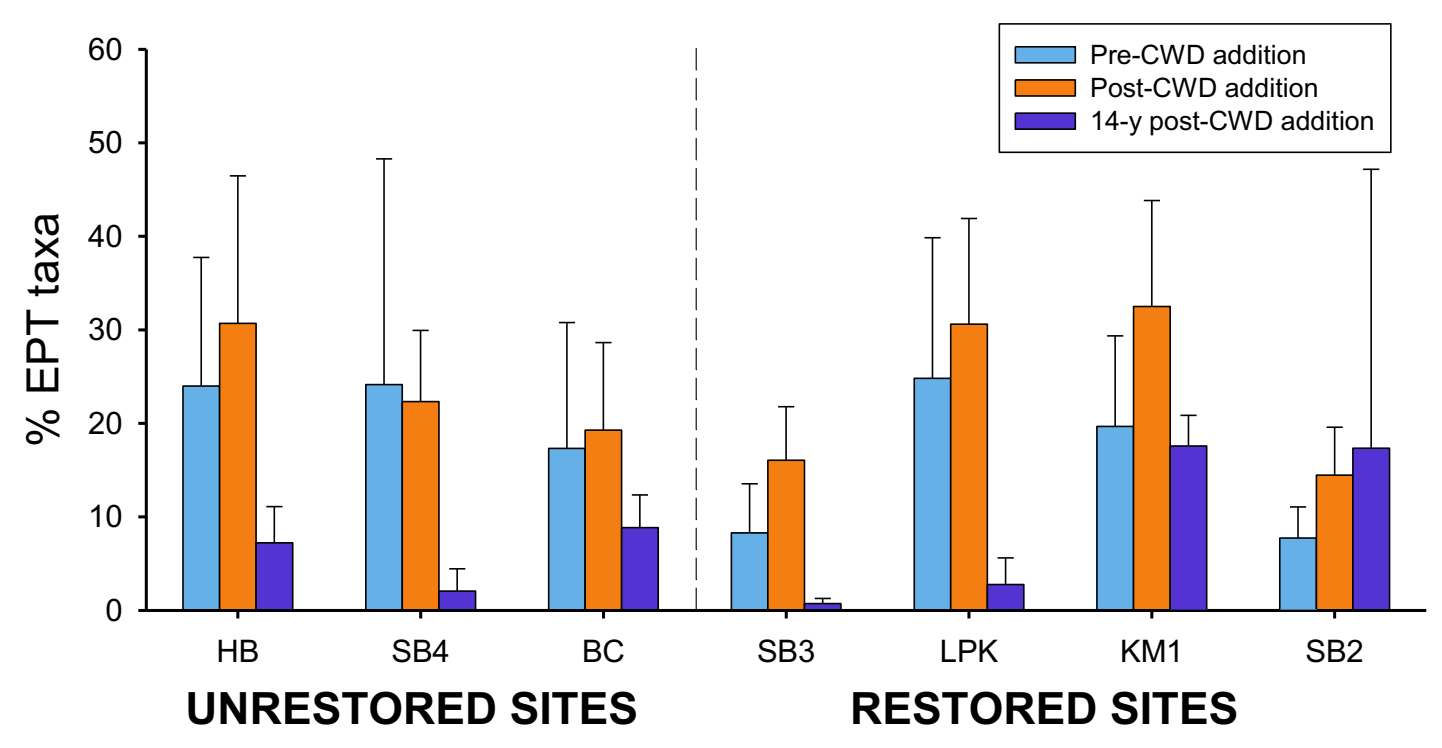

Figure 20 - Mean (+ standard deviation) percentage of Ephemeroptera, Plecoptera, and Trichoptera taxa (\%EPT) in unrestored (HB, SB4, BC) and restored (SB3, LPK, KM1, SB2) streams in the pre-restoration period (2001-2002; blue bars), immediately after restoration (2004-2006; orange bars), and 14-y post-restoration (2017-2018; purple bars). Data are stream averages across all seasons. Data from the original project are from Mulholland et al. (2007). 


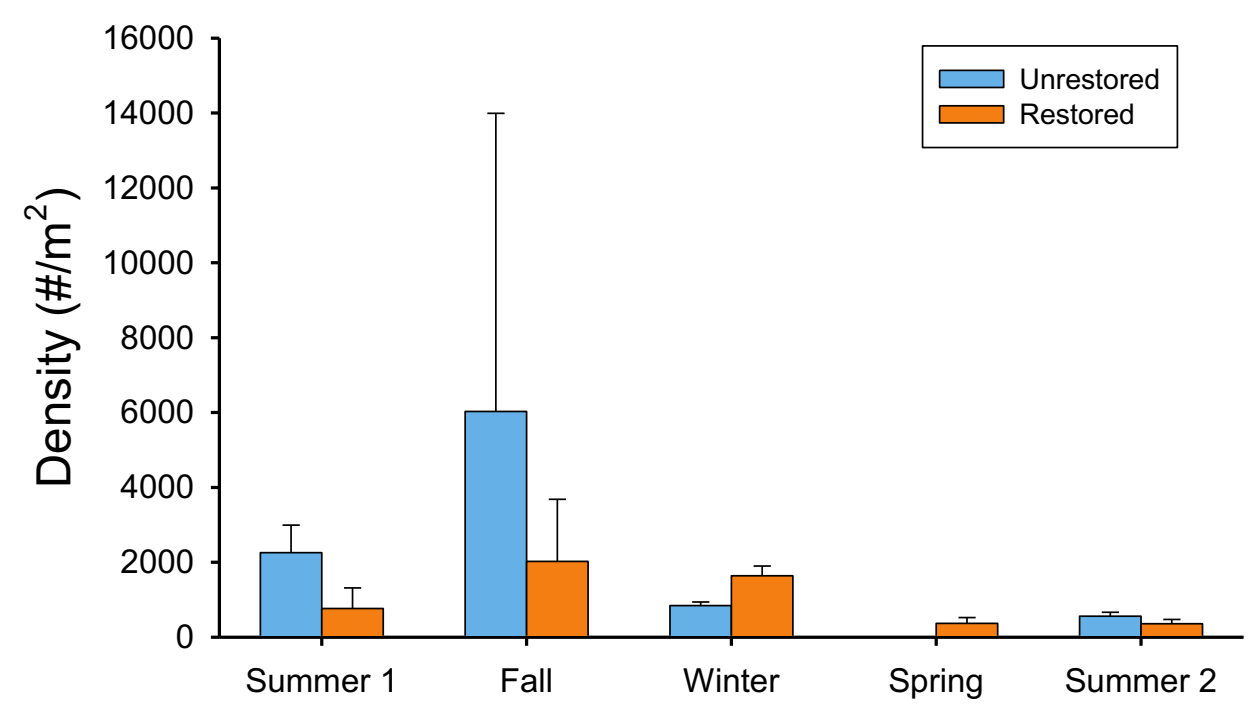

Figure 21 - Mean (+ standard deviation) total macroinvertebrate density (\# individuals/m²) in unrestored (blue) and restored (orange) streams in each of 5 sampling seasons (August 2017 [Summer1], November 2017 [Fall], February 2018 [Winter], April 2018 [Spring], and September 2018 [Summer2]) in the 14-y post-restoration period.

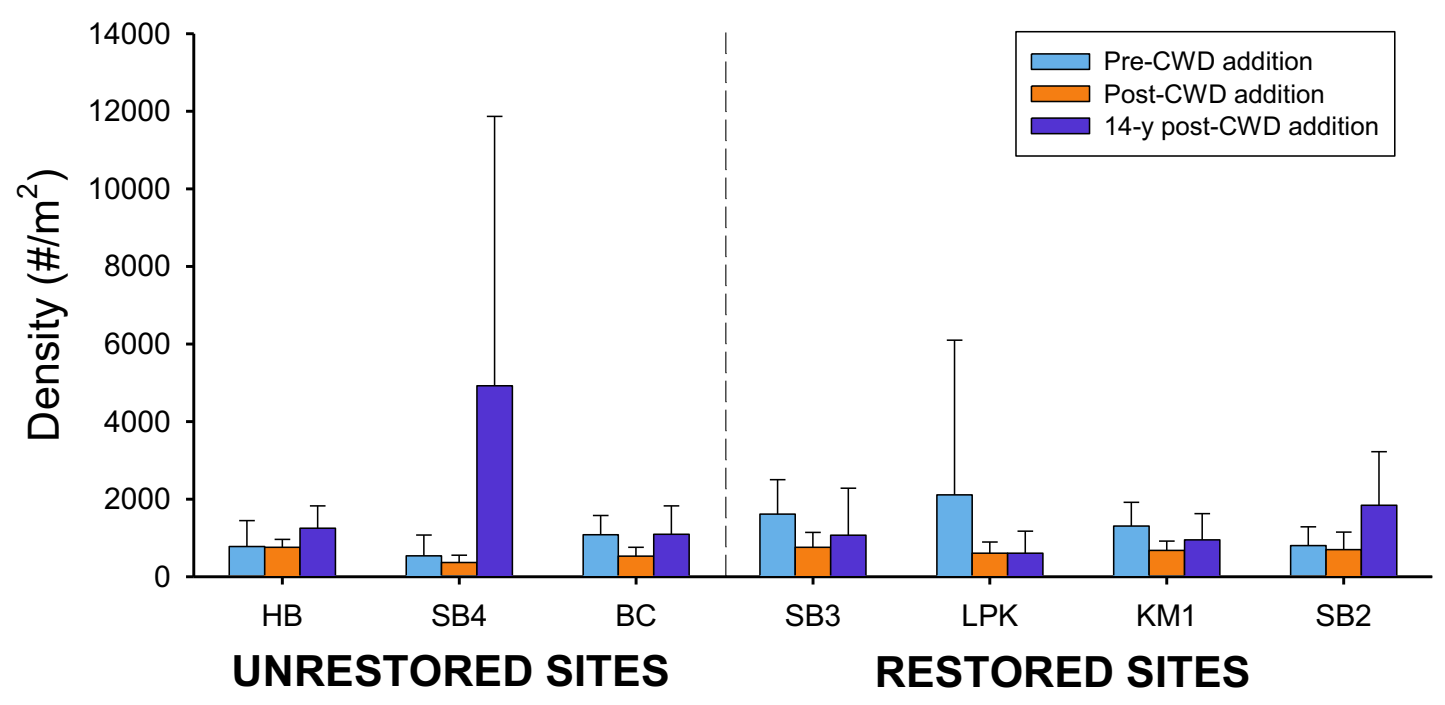

Figure 22 - Mean (+ standard deviation) total macroinvertebrate density (\# individuals $/ \mathbf{m}^{2}$ ) in unrestored (HB, SB4, BC) and restored (SB3, LPK, KM1, SB2) streams in the prerestoration period (2001-2002; blue bars), immediately after restoration (2004-2006; orange bars), and 14-y post-restoration (2017-2018; purple bars). Data are stream averages across all seasons. Data from the original project are from Mulholland et al. (2007). 


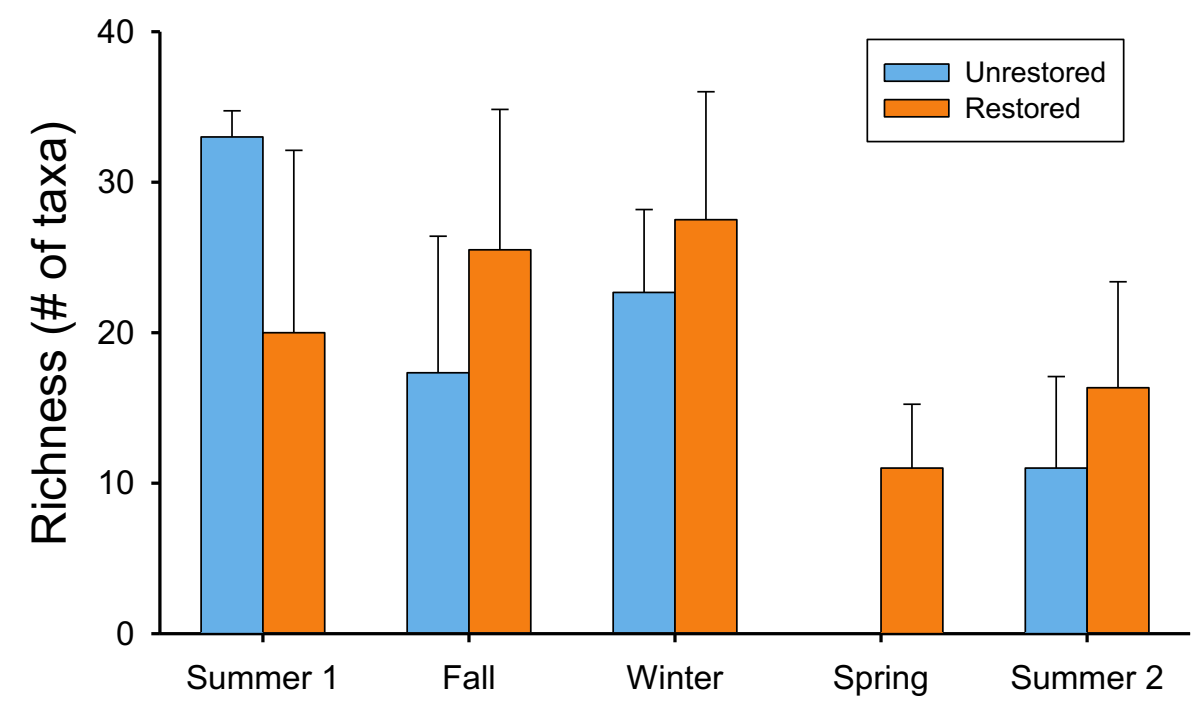

Figure 23 - Mean (+ standard deviation) macroinvertebrate taxonomic richness (\# of taxa) in unrestored (blue) and restored (orange) streams in each of 5 sampling seasons (August 2017 [Summer1], November 2017 [Fall], February 2018 [Winter], April 2018 [Spring], and September 2018 [Summer2]) in the 14-y post-restoration period.

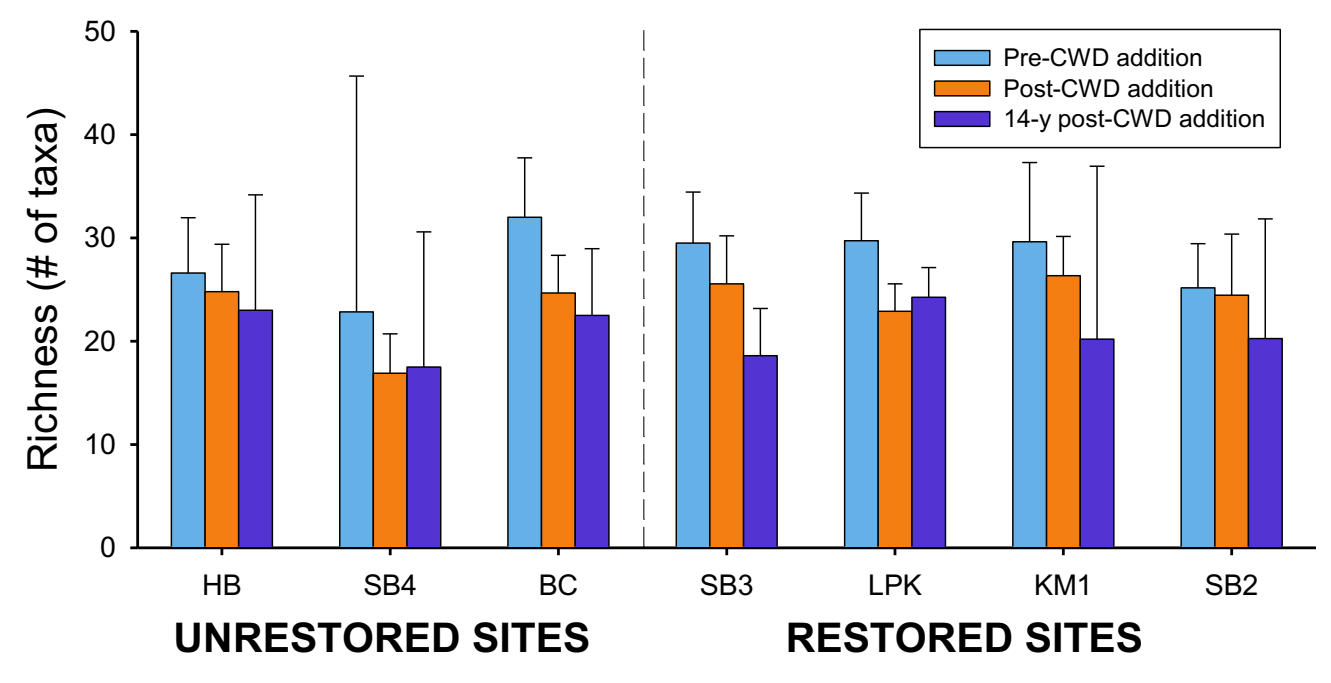

Figure 24 - Mean (+ standard deviation) macroinvertebrate taxonomic richness (\# of taxa) in unrestored $(\mathrm{HB}, \mathrm{SB} 4, \mathrm{BC})$ and restored $(\mathrm{SB3}, \mathrm{LPK}, \mathrm{KM1}, \mathrm{SB} 2)$ streams in the prerestoration period (2001-2002; blue bars), immediately after restoration (2004-2006; orange bars), and 14-y post-restoration (2017-2018; purple bars). Data are stream averages across all seasons. Data from the original project are from Mulholland et al. (2007). 


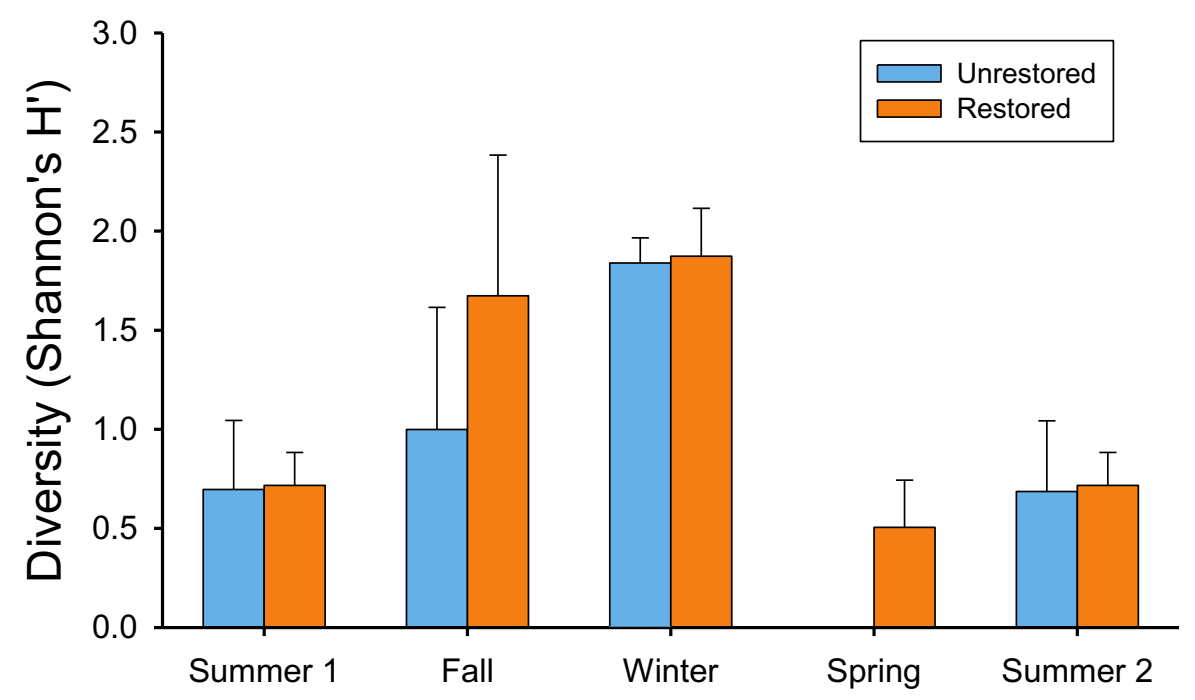

Figure 25 - Mean (+ standard deviation) macroinvertebrate taxonomic diversity (Shannon's $H^{\prime}$ ) in unrestored (blue) and restored (orange) streams in each of 5 sampling seasons (August 2017 [Summer1], November 2017 [Fall], February 2018 [Winter], April 2018 [Spring], and September 2018 [Summer2]) in the 14-y post-restoration period.

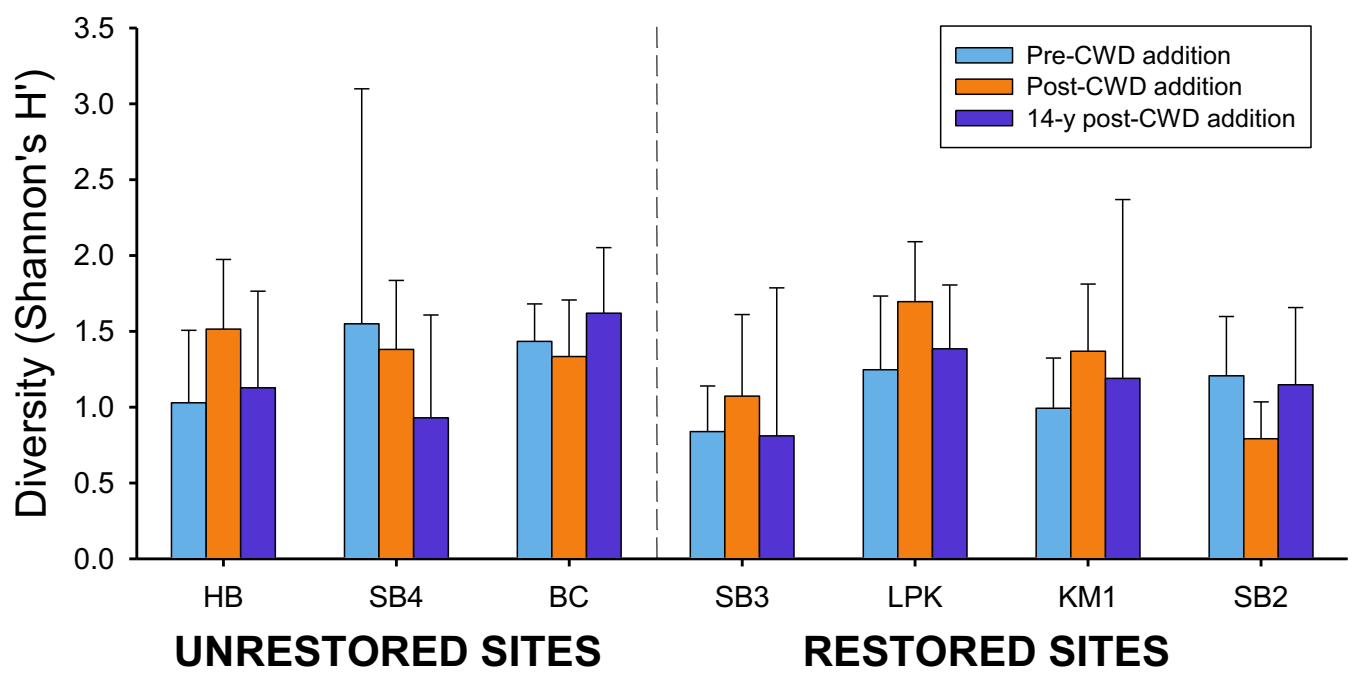

Figure 26 - Mean (+ standard deviation) macroinvertebrate taxonomic diversity (Shannon's $H^{\prime}$ ) in unrestored (HB, SB4, BC) and restored (SB3, LPK, KM1, SB2) streams in the pre-restoration period (2001-2002; blue bars), immediately after restoration (20042006; orange bars), and 14-y post-restoration (2017-2018; purple bars). Data are stream averages across all seasons. Data from the original project are from Mulholland et al. (2007). 


\subsubsection{Disturbance Analysis}

Measure of disturbance: The estimate of watershed disturbance using 2016 NLCD data was different (Welch two-sample $\mathrm{t}$-test, $\mathrm{p}<0.01, \mathrm{t}=3.8$ ) than reported by the original project (Maloney et al. 2005, Table 3). The land-cover dataset used in the original study was created using $0.5-\mathrm{m}$ resolution aerial imagery and was ground-truthed by FBMI staff (personal communication, Kelly Maloney), which resulted in more accurate classification than the NLCD dataset. In comparing \% watershed disturbance calculated from the 2001 NLCD dataset (reflecting land cover during the original project) and the 2016 NLCD dataset (reflecting land cover during the current project), we found no difference in $\%$ watershed disturbance between 2001 and 2016. Because there were no significant changes in \% watershed disturbance between the original project and the current project (based on 2001 vs. 2016 NLCD data), and because of the greater accuracy of the Maloney et al. (2005) data, \% watershed disturbance numbers reported in Maloney et al. (2005) were used for the subsequent disturbance analyses.

Effect of disturbance on ecosystem functions: Before the CWD additions, nutrient uptake and whole-stream metabolism metrics were correlated with \% watershed disturbance (Houser et al. 2005, Mulholland et al. 2005, Roberts et al. 2007a). Analysis of the effect of \% watershed disturbance on whole-stream metabolism by restoration period found that $\%$ watershed disturbance was negatively correlated with the maximum daily DO deficit (ER indicator) in the pre-restoration $\left(\mathrm{p}<0.01, \mathrm{r}^{2}=0.16\right)$ and post-restoration periods $\left(\mathrm{p}<0.01, \mathrm{r}^{2}=0.08\right)$, and was not significantly correlated in the 14-y post-restoration period $\left(\mathrm{p}=0.67, \mathrm{r}^{2}<0.01\right)$ (Figure 27). The percentage of watershed disturbance was negatively correlated with the amplitude of the daily DO deficit (GPP indicator) in the pre-restoration period $\left(\mathrm{p}=0.01, \mathrm{r}^{2}=0.06\right)$, marginally significantly correlated during the post-restoration period $\left(\mathrm{p}=0.06, \mathrm{r}^{2}=0.01\right)$, and positively correlated in the 14-y post-restoration period $\left(\mathrm{p}=0.04, \mathrm{r}^{2}=0.03\right)$ (Figure 27). When analyzed across the entire 14-y study period, $\%$ watershed disturbance was not significantly correlated with either the maximum daily DO deficit or the daily amplitude of the DO deficit (all $\mathrm{p}>0.1)$.

Table 3 - Watershed disturbance intensity (\% catchment), as calculated in Maloney et al. (2005) and using the 2016 National Land Cover Dataset (NLCD), across the 7 study sites.

\begin{tabular}{cccc}
\hline \hline Stream & $\begin{array}{c}\text { Catchment } \\
\text { area (ha) }\end{array}$ & $\begin{array}{c}\text { Disturbance } \\
\text { intensity from } \\
\text { Maloney et al. (2005) } \\
\text { (\% catchment) }\end{array}$ & $\begin{array}{c}\text { Disturbance intensity } \\
\text { from NLCD 2016 data } \\
\text { (\% catchment) }\end{array}$ \\
\hline $\begin{array}{c}\text { Unrestored } \\
\text { HB }\end{array}$ & 215 & 6.6 & 3.2 \\
SB4 & 100 & 13.7 & 4.3 \\
BC & 210 & 10.5 & 2.6 \\
Restored & & 10.5 & 4.4 \\
SB3 & 72 & 11.3 & 0.02 \\
LPK & 33 & 4.6 & 0.2 \\
KM1 & 369 & 8.1 & 0.8 \\
SB2 & 123 & & \\
\hline \hline
\end{tabular}


There were also negative correlations between whole-stream metabolism indicators and $\%$ watershed disturbance in certain seasons. Percentage watershed disturbance was negatively correlated with the maximum daily DO deficit (an indicator of ER) in the spring of 2004 ( $p=$ $\left.0.03, r^{2}=0.73\right)$, fall of $2004\left(p=0.05, r^{2}=0.65\right)$, and spring of $2018\left(p=0.02, r^{2}=0.79\right)$. The relationship between \% watershed disturbance and the maximum daily DO deficit was also marginally significant in the fall of $2005\left(\mathrm{p}=0.09, \mathrm{r}^{2}=0.55\right)$ (Table 4). The amplitude of the daily DO deficit (an indicator of GPP) was also negatively correlated with $\%$ watershed disturbance in the summer of $2017\left(\mathrm{p}<0.01, \mathrm{r}^{2}=0.98\right)$ and the fall of $2018\left(\mathrm{p}=0.02, \mathrm{r}^{2}=0.96\right)$, and was marginally significant in the spring of $2004\left(\mathrm{p}=0.07, \mathrm{r}^{2}=0.61\right)$ (Table 4).

For ammonium uptake metrics, areal uptake rate $(U)$ was marginally negatively correlated with the $\%$ watershed disturbance in the post-restoration period $\left(\mathrm{p}=0.07, \mathrm{r}^{2}=0.09\right)$ (Figure 28). Uptake velocity $\left(v_{f}\right)$ was significantly negatively correlated with $\%$ watershed disturbance during the post-restoration period $\left(\mathrm{p}=0.03, \mathrm{r}^{2}=0.13\right)$ and marginally correlated during the prerestoration period $\left(\mathrm{p}=0.07, \mathrm{r}^{2}=0.60\right)$ (Figure 28$)$. There was no statistically significant correlation between $\%$ watershed disturbance and $U$ during the pre-restoration period $(\mathrm{p}=0.11$, $\left.\mathrm{r}^{2}=0.51\right)$ or the $14-\mathrm{y}$ post-restoration period $\left(\mathrm{p}=0.70, \mathrm{r}^{2}<0.01\right)$. There was no statistically significant correlation between $\%$ watershed disturbance and $v_{f}$ during the 14-y post-restoration period $\left(\mathrm{p}=0.85, \mathrm{r}^{2}<0.01\right)$. When analyzed across the entire $14-\mathrm{y}$ study period, $\%$ watershed disturbance was not significantly correlated with $U\left(\mathrm{p}=0.30, \mathrm{r}^{2}=0.02\right)$ or $v_{f}\left(\mathrm{p}=0.50, \mathrm{r}^{2}<0.01\right)$ (Figure 29). 

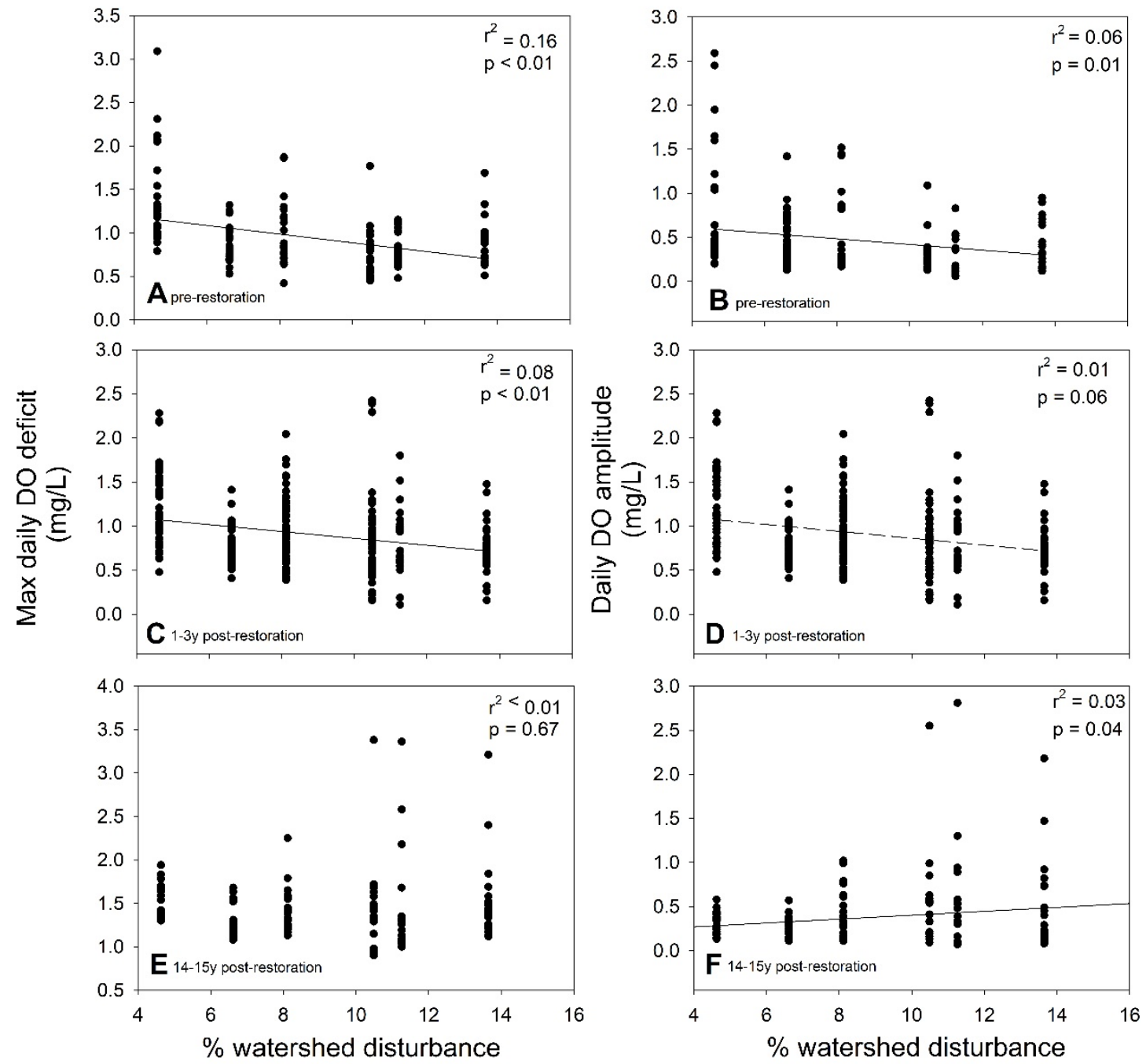

Figure 27 - Relationships between \% watershed disturbance, as calculated in Maloney et al. (2005), and (A) maximum dissolved oxygen (DO) deficit (an indicator of ecosystem respiration, in $\mathrm{mg} / \mathrm{L}$ ) in the pre-restoration period (2001-2003), (B) daily DO deficit amplitude (an indicator of gross primary production, in $\mathrm{mg} / \mathrm{L}$ ) in the pre-restoration period, (C) maximum DO deficit immediately after restoration (2004-2006), (D) daily DO deficit amplitude immediately after restoration, (E) maximum daily DO deficit 14-y postrestoration (2017-2018), and (F) daily DO deficit amplitude 14-y post-restoration.

Significant regressions are indicated by solid lines and marginally significant regressions are indicated by dashed lines. 
Table 4 - Results from the linear regression analyses (adjusted $\mathbf{r}^{2}$ - and $\mathbf{p}$-values) of the effects of \% watershed disturbance on mean maximum daily dissolved oxygen (DO) deficit and mean daily DO deficit amplitude by year, season, and period (prerestoration [PRE; 2001-2003], immediately post-restoration [PR; 2004-2006], and 14-y post-restoration [14-y PR; 2017-2018]). Bold text represents significant $p$-values $(p \leq 0.05)$, and italicized text represents marginally significant $p$-values $(>0.05$ and $\leq 0.1)$.

\begin{tabular}{|c|c|c|c|c|c|c|c|c|}
\hline Period & Year & Season & Direction & $\begin{array}{c}\text { Max daily DO } \\
\text { deficit } \mathbf{r}^{2}\end{array}$ & $\begin{array}{c}\text { Max daily DO } \\
\text { deficit } \\
\text { p-value }\end{array}$ & Direction & $\begin{array}{c}\text { Daily DO } \\
\text { deficit } \\
\text { amplitude } \mathbf{r}^{2} \\
\end{array}$ & $\begin{array}{c}\text { Daily DO deficit } \\
\text { amplitude } \\
\text { p-value } \\
\end{array}$ \\
\hline$\overline{\text { PRE }}$ & 2001 & Summer & - & 0.67 & 0.18 & + & 0.59 & 0.24 \\
\hline PRE & 2001 & Fall & - & 0.24 & 0.32 & - & 0.10 & 0.54 \\
\hline PRE & 2002 & Winter & - & 0.01 & 0.85 & - & 0.19 & 0.39 \\
\hline PRE & 2002 & Spring & - & 0.27 & 0.29 & - & 0.30 & 0.26 \\
\hline PRE & 2002 & Summer & - & 0.01 & 0.88 & + & 0.19 & 0.46 \\
\hline PRE & 2002 & Fall & - & 0.04 & 0.70 & - & 0.50 & 0.11 \\
\hline PRE & 2003 & Winter & - & 0.42 & 0.16 & - & 0.14 & 0.46 \\
\hline PRE & 2003 & Spring & - & 0.28 & 0.36 & - & 0.46 & 0.21 \\
\hline PRE & 2003 & Summer & - & 0.10 & 0.69 & + & 0.00 & 0.99 \\
\hline PR & 2004 & Winter & - & 0.01 & 0.88 & + & 0.05 & 0.67 \\
\hline PR & 2004 & Spring & - & 0.73 & 0.03 & - & 0.61 & 0.07 \\
\hline PR & 2004 & Summer & - & 0.29 & 0.27 & + & 0.18 & 0.40 \\
\hline PR & 2004 & Fall & - & 0.65 & 0.05 & - & 0.09 & 0.56 \\
\hline PR & 2005 & Winter & - & 0.01 & 0.88 & - & 0.00 & 0.94 \\
\hline PR & 2005 & Spring & - & 0.03 & 0.77 & - & 0.56 & 0.14 \\
\hline PR & 2005 & Summer & - & 0.29 & 0.35 & + & 0.12 & 0.58 \\
\hline PR & 2005 & Fall & - & 0.50 & 0.18 & + & 0.14 & 0.54 \\
\hline PR & 2006 & Winter & + & 0.52 & 0.11 & + & 0.00 & 0.95 \\
\hline PR & 2006 & Spring & - & 0.55 & 0.09 & - & 0.05 & 0.67 \\
\hline PR & 2006 & Summer & - & 0.04 & 0.71 & + & 0.04 & 0.70 \\
\hline PR & 2006 & Fall & - & 0.02 & 0.81 & + & 0.36 & 0.21 \\
\hline 14-y PR & 2017 & Summer & + & 0.50 & 0.12 & + & 0.98 & $<0.01$ \\
\hline 14-y PR & 2017 & Fall & - & 0.73 & 0.15 & - & 0.96 & 0.02 \\
\hline 14-y PR & 2018 & Spring & - & 0.79 & 0.02 & - & 0.37 & 0.20 \\
\hline 14-y PR & 2018 & Summer & - & 0.07 & 0.67 & + & 0.10 & 0.61 \\
\hline 14-y PR & 2018 & Fall & + & 0.02 & 0.79 & - & 0.00 & 0.97 \\
\hline
\end{tabular}



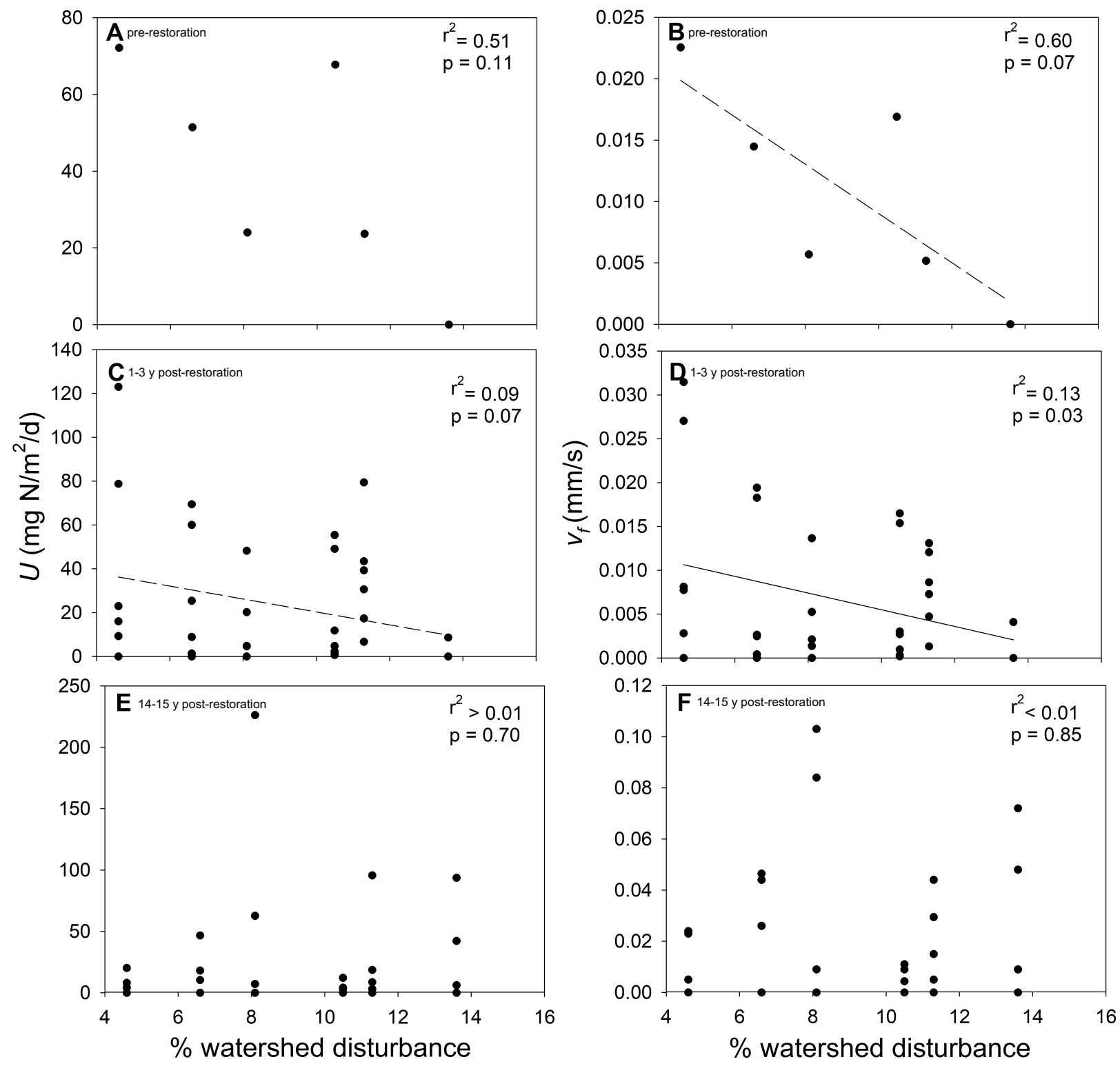

Figure 28 - Relationships between \% watershed disturbance and (A) areal uptake rate of ammonium $\left(U ; \mathrm{mg} \mathrm{N} / \mathrm{m}^{2} / \mathrm{d}\right)$ in the pre-restoration period (2001-2003), (B) uptake velocity of ammonium $\left(v_{f}, \mathrm{~mm} / \mathrm{s}\right)$ in the pre-restoration period, $(\mathrm{C}) \boldsymbol{U}$ immediately after restoration (2004-2006), (D) $v_{f}$ immediately after restoration, (E) $U$ 14-y post-restoration (2017-2018), and (F) $v_{\boldsymbol{f}}$ 14-y post-restoration. Significant regressions are indicated by solid lines and marginally significant regressions are indicated by dashed lines. 

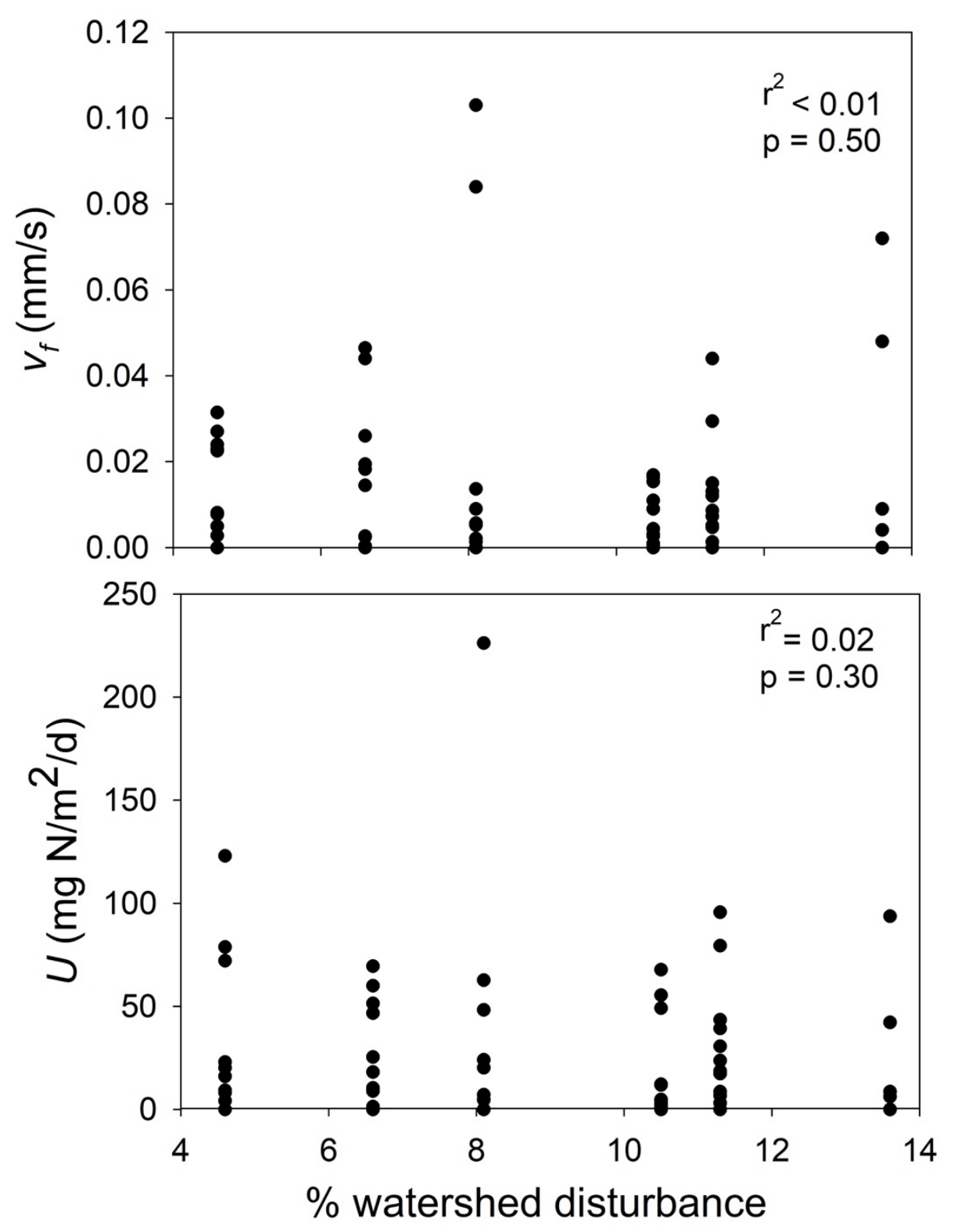

Figure 29 - Relationships between \% watershed disturbance and ammonium uptake velocity $\left(v_{f}\right.$ in $\mathrm{mm} / \mathrm{s}$; top panel) and areal uptake rate of ammonium $\left(U\right.$ in $\mathrm{mg} \mathrm{N} / \mathrm{m}^{2} / \mathrm{d}$; bottom panel) across all streams and years.

Effect of disturbance on water quality metrics: Several water quality metrics were correlated with $\%$ watershed disturbance prior to restoration (Houser et al. 2005). When analyzing the entire 14-y dataset by restoration period, we found that the $\%$ of watershed disturbance was significantly correlated with TSS, $\mathrm{NH}_{4}, \mathrm{SRP}$, and DOC, though the relationships varied in strength or were absent during certain restoration periods (Table 5). There were no significant correlations with $\mathrm{NO}_{3}$ during any period (Table 5). When analyzing the entire 14-y dataset together, $\%$ watershed disturbance was significantly correlated with these same four water quality parameters (Figure 30). 
Table 5 - Results from the linear regression analyses (adjusted $\mathbf{r}^{2}$ - and $\mathbf{p}$-values) of the effects of \% watershed disturbance on water quality metrics (total suspended solids [TSS], nitrate $\left[\mathrm{NO}_{3}\right]$, ammonium $\left[\mathrm{NH}_{4}\right]$, soluble reactive phosphorus [SRP], and dissolved organic carbon [DOC] concentrations) across pre-restoration (PRE; 2001-2003), immediately postrestoration (PR; 2004-2006), and 14-y post-restoration (14-y PR; 2017-2018) periods. Bold text represents significant $p$-values $(p \leq 0.05)$, and italicized text represents marginally significant $p$-values $(>0.05$ and $\leq 0.1)$.

\begin{tabular}{llccc}
\hline $\begin{array}{c}\text { Water quality } \\
\text { metric }\end{array}$ & \multicolumn{1}{c}{ Period } & Direction & $\mathbf{r}^{\mathbf{2}}$ & p-value \\
\hline $\mathrm{TSS}$ & PRE & + & $\mathbf{0 . 0 7}$ & $<\mathbf{0 . 0 1}$ \\
& PR & + & $\mathbf{0 . 0 8}$ & $<\mathbf{0 . 0 1}$ \\
& $14-\mathrm{y} \mathrm{PR}$ & + & 0.18 & 0.12 \\
\hline $\mathrm{NO}_{3}$ & PRE & - & $<0.01$ & 0.86 \\
& PR & - & 0.02 & 0.16 \\
& $14-y$ PR & - & 0.14 & 0.19 \\
\hline $\mathrm{NH}_{4}$ & PRE & + & $\mathbf{0 . 2 3}$ & $<\mathbf{0 . 0 1}$ \\
& PR & + & $\mathbf{0 . 1 5}$ & $<\mathbf{0 . 0 1}$ \\
& $14-y$ PR & + & $\mathbf{0 . 1 8}$ & $<\mathbf{0 . 0 1}$ \\
\hline $\mathrm{SRP}$ & PRE & - & $\mathbf{0 . 0 7}$ & $<\mathbf{0 . 0 1}$ \\
& PR & + & $<0.01$ & 0.96 \\
& $14-y$ PR & - & 0.01 & 0.34 \\
\hline DOC & PRE & - & $\mathbf{0 . 3 2}$ & $<\mathbf{0 . 0 1}$ \\
& PR & - & $\mathbf{0 . 3 2}$ & $<\mathbf{0 . 0 1}$ \\
& $14-y$ PR & - & 0.03 & 0.10 \\
\hline \hline
\end{tabular}



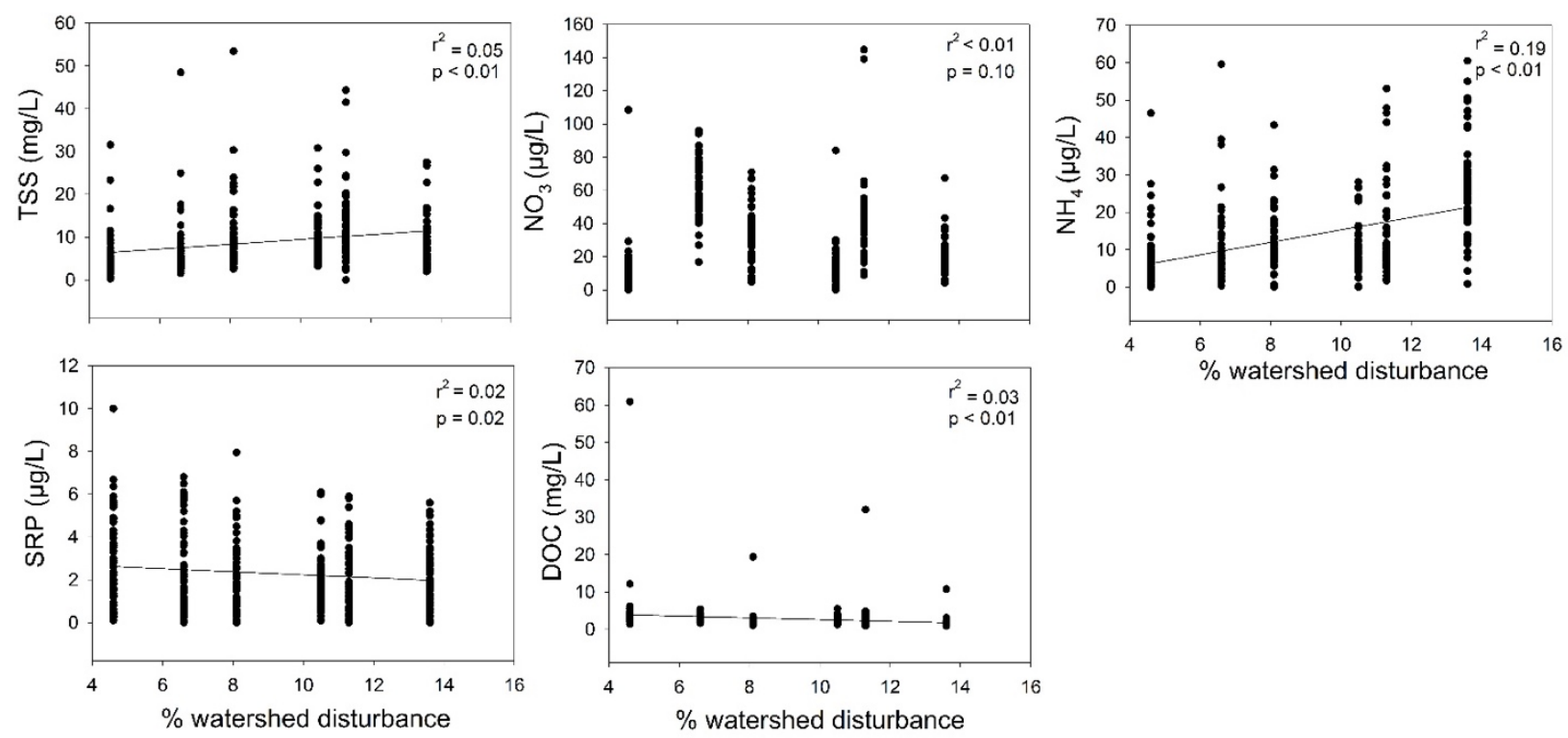

Figure 30 - Relationships between \% watershed disturbance and water quality metrics (top left to bottom right panels: total suspended solid [TSS], nitrate [ $\left.\mathrm{NO}_{3}\right]$, ammonium [ $\left.\mathrm{NH}_{4}\right]$, soluble reactive phosphorus [SRP], and dissolved organic carbon [DOC] concentrations) for the entire 14-y dataset. Significant regressions are indicated by solid lines and marginally significant regressions are indicated by dashed lines.

\section{CONCLUSIONS AND IMPLICATIONS FOR FUTURE RESEARCH/IMPLEMENTATION}

The overall objective of this project was to evaluate the long-term efficacy of restorations that were implemented at FBMI by assessing stream ecosystem responses $\sim 14$ years after installation. The specific objectives were to determine if the improvements to ecosystem condition that were observed immediately (1-3 years) after restoration were still in an improved state $\sim 14$ years postrestoration, or were no longer showing improvements (i.e., return to pre-treatment conditions), and determine if the ecosystem parameters that did not change immediately (1-3 years) after restoration have since responded to restoration, or still showed no change with restoration. In 2017-2018, our project successfully collected and analyzed $\sim 1.5$ years of stream response data, including $\sim$ monthly measurements of water quality, and seasonal measurements of ammonium uptake, stream metabolism indicators, BPOM, and macroinvertebrates. From these analyses, our overarching conclusion was that instream restorations (i.e., CWD additions that took place $\sim 14$ years ago) at FBMI had minimal long-term effects on stream ecosystem structure (i.e., water quality, BPOM, macroinvertebrates) and function (i.e., nutrient uptake, stream metabolism).

The instream restoration in 2003 resulted in a doubling of CWD in the restored stream channels (Mulholland et al. 2007). While added CWD dams were still visible $\sim 14$ years after the initial restoration, and there was an overall increase in CWD coverage in all streams in 2018 compared to 2003-2006, the coverage of CWD in restored streams was no longer greater than in unrestored streams. Thus, CWD levels appear to show no long-term restoration effect and temporal differences were likely the result of environmental variation that has occurred at all sites over the 
14-y period. It is also possible that the structural properties of the CWD dams changed over time; however, a detailed characterization of the CWD dams was not within the scope of this study. Similar to the changes in CWD dam abundance observed over time, we found that BPOM increased systematically across the study streams over the past 14 years; however, any direct long-term benefit (i.e., increased BPOM standing stocks) associated with CWD additions was not supported.

There were no long-term effects of restoration on water quality parameters, which was consistent with the original study in these FBMI streams that found no short-term effects of CWD additions on water quality (Mulholland et al. 2007). However, in 2017-2018, TSS concentrations were higher in restored vs. unrestored streams, and DOC concentrations were higher in unrestored vs. restored streams, but only in winter. These observed differences between restored and unrestored streams in the 14-y post-restoration period may have reflected sampling during high-water events that followed heavy rains, instead of an effect of CWD additions. Sampling during these higherflow periods was often unavoidable due to strict site access controls due to military training activities. There were also seasonal and longer-term changes in some water quality metrics (i.e., $\mathrm{pH}$, and ammonium, nitrate, and SRP concentrations), again likely reflecting environmental variation over these various time scales. While multiple studies have examined drivers of seasonal (e.g., Roberts and Mulholland 2007) and interannual (e.g., Lutz et al. 2012) variation in water quality parameters, this was not the focus of the current study. Thus, we do not have specific environmental data that can be used to explore the potential factors that may be influencing these temporal patterns.

Ammonium uptake rates increased immediately (i.e., one month) after CWD was added to restored streams (Roberts et al. 2007a). The enhanced capacity of these streams to remove nutrients likely reflected a combination of increased nutrient demand by microorganisms and macroalgae that colonized CWD and associated organic matter, and changes in stream hydraulics resulting in increased water residence time (Roberts et al. 2007a). However, this nutrient uptake response was short lived, and there was no consistent long-term effect of CWD additions on ammonium uptake rates. Ammonium uptake rates ( $U$ and $v_{f}$ ) showed some treatment responses in some seasons and time periods. For example, ammonium uptake was lower in restored than unrestored streams in spring in the 14-y post-restoration period, which was opposite our hypothesis of increased uptake in restored streams. However, due to site access issues, measurement of nutrient uptake in 2 of the 7 streams occurred a month before measurements in the other 5 streams, and thus temporal variability in nutrient uptake during this spring period may have partially contributed to the difference between restored and unrestored streams. Ammonium uptake rates were generally higher in some, but not all, streams 14-y post-restoration compared to immediately after restoration (i.e., uptake rates in 2004 and 2005). Again, this may reflect environmental and climatic variation over longer time periods, and may be associated with the overall greater CWD cover and BPOM standing stocks observed across most streams.

While the original project found increased rates of ER and GPP with restoration in the first 1.5 years post-restoration (Mulholland et al. 2007), analysis of the 14-year post-restoration period found no long-term effect of restoration on stream metabolism indicators. Similar to many of the other stream ecosystem structure and function variables that were measured in this study, we found that metabolism indicators varied over both the short- (i.e., seasonal) and longer-term. These temporal patterns may have been driven by a variety of environmental (e.g., light 
availability, organic matter inputs) and climatic (e.g., dry vs. wet years) factors (e.g., Roberts et al. 2007b, Griffiths et al. 2013).

Finally, there were no clear effects of CWD additions on macroinvertebrate community metrics. Instead, the macroinvertebrate results suggest that there was considerable variation in biotic responses in these systems. Many streams are on unique trajectories and are at different states in terms of contemporary disturbance, recovery from past disturbance, and associated biotic assemblages. This can result in considerable spatial variation across the study area. Further, most metrics showed strong seasonal and period effects, reflecting short- and long-term temporal patterns. This temporal variation is likely a function of seasonal variations and water-year fluctuations in precipitation and groundwater contributions to streamflow. This spatial, and particularly temporal, variation observed may have masked any long-term influence of CWD augmentation as habitat restoration in these streams.

To conclude, this study found minimal long-term (i.e., 14-y) enhancement of stream structural and functional responses to CWD additions as a restoration technique. Instead, there was considerable variability in the measured responses both among streams, and across seasons and time periods, likely due to environmental and climatic variation acting at multiple temporal and spatial scales. While these results suggest a minimal long-term effect of CWD dams, these findings may not be applicable to all stream ecosystems. Some of the lack of effect may have been due to burial of CWD by sediment in these sandy-bottomed and dynamic streams (Mulholland et al. 2007). Therefore, implementation of this technology in headwater streams on DoD lands in the Coastal Plain may require frequent augmentation of CWD dams; this hypothesis requires investigation.

Analysis of NLCD data suggested that upland disturbances have not changed at FBMI over this 14-year period, and in fact, we observed correlations between some stream metrics and \% watershed disturbance that were indicative of increasingly impaired conditions with disturbance, although the explanatory power $\left(\mathrm{r}^{2}\right)$ of these relationships was often low. One of the motivations behind the restorations at FBMI was to mitigate the effects of upland disturbance on stream ecosystems (Houser et al. 2005, Mulholland et al. 2005, Roberts et al. 2007a), and we found that some of these relationships continued to exist into the present day; however, these effects were not consistent across all metrics and all seasons. These findings suggest that instream restorations that occur at small spatial scales may not be effective if larger scale (i.e., watershed or landscapelevel) stressors are not also addressed (NRC 1992, Craig et al. 2008, Roni et al. 2008, Bernhardt and Palmer 2011).

Lastly, the current study only measured responses for a period of 1.5 years, and hydrologic flows during this time ranged from historically high flows to historically low flows (United States Geological Survey [USGS] stream gage 02341800, Upatoi Creek near Columbus, Georgia). As all of the measured processes varied both seasonally and over the longer term, this suggests that assessments of restoration efficacy should similarly occur over a longer period of time in order to capture seasonal and interannual variability in environmental and climatic conditions; this should be a focus of future studies of restoration efficacy. Long-term assessments of stream restorations are exceedingly rare, and thus results from this study fill an important knowledge gap on the long-term efficacy of instream CWD restoration in southeastern Coastal Plain streams in the US. 


\section{LITERATURE CITED}

Alexander, R.B., J.R. Slack, A.S. Ludtke, K.K. Fitzgerald, and T.L. Schertz. 1998. Data from selected U.S. Geological Survey national stream water quality monitoring networks. Water Resources Research 34:2401-2405.

Allan, J.D. 2004. The influence of land use on stream ecosystems. Annual Review of Ecology, Evolution, and Systematics 35:257-284.

American Public Health Association (APHA). 2005. Standard methods for the examination of water and wastewater, $21^{\text {st }}$ edition. APHA, Washington, DC.

Appling, A.P., R.O. Hall Jr., C.B. Yackulic, and M. Arroita. 2018. Overcoming equifinality: leveraging long time series for stream metabolism estimation. JGR-Biogeosciences 123:624645.

Barbour, M.T., J. Gerritsen, B.D. Snyder, and J.B. Stribling. 1999. Rapid bioassessment protocols for use in streams and wadeable rivers: periphyton, benthic macroinvertebrates, and fish. Second edition. EPA 841-B-99-02. U.S. EPA, Washington DC.

Bernhardt, E.S., and M.A. Palmer. 2011. River restoration: the fuzzy logic of repairing reaches to reverse catchment scale degradation. Ecological Applications 21:1926-1931.

Bernhardt, E.S., M.A. Palmer, J.D. Allan, G. Alexander, K. Barnas, S. Brooks, J. Carr, S. Clayton, C. Dahm, J. Follstad-Shah, D. Galat, S. Gloss, P. Goodwin, D. Hart, B. Hassett, R. Jenkinson, S. Katz, G.M. Kondolf, P.S. Lake, R. Lave, J.L. Meyer, T.K. O’Donnell, L. Pagano, B. Powell, and E. Sudduth. 2005. Synthesizing U.S. river restoration efforts. Science 308:636-637.

Bilby, R.E., and G.E. Likens. 1980. Importance of organic debris dams in the structure and function of stream ecosystems. Ecology 61:1107-1113.

Bilby, R.E., and J.W. Ward. 1991. Characteristics and function of large woody debris in streams draining old-growth, clear-cut, and second-growth forests in southwestern Washington. Canadian Journal of Fisheries and Aquatic Sciences 48:2499-2508.

Bond, N.R., and P.S. Lake. 2003. Local habitat restoration in streams: constraints on the effectiveness of restoration for stream biota. Ecological Management and Restoration 4:193198.

Craig, L.S., M.A. Palmer, D.C. Richardson, S. Filoso, E.S. Bernhardt, B.P. Bledsoe, M.W. Doyle, P.M. Groffman, B.A. Hassett, S.S. Kaushal, P.M. Mayer, S.M. Smith, and P.R. Wilcock. 2008. Stream restoration strategies for reducing river nitrogen loads. Frontiers in Ecology and the Environment 6:529-538.

Dale, V.H., S.C. Beyeler, and B. Jackson. 2002. Understory vegetation indicators of anthropogenic disturbance in longleaf pine forests at Fort Benning, Georgia, USA. Ecological Indicators 1:155-170.

Downing, J.A., Y.T. Prairie, J.J. Cole, C.M. Duarte, L.J. Tranvik, R.G. Striegl, W.H. McDowell, P. Kortelainen, N.F. Caraco, J.M. Melack, and J.J. Middelburg. 2006. The global abundance and size distribution of lakes, ponds, and impoundments. Limnology and Oceanography 51:2388-2397. 
Ebert, D.W., and T.G. Wade. 2004. Analytical tools interface for landscape assessments (ATTILA) user guide: version 2004. Office of Research and Development. U.S. EPA, Las Vegas, Nevada.

Epler, J.H. 2001. Identification manual for the larval Chironomidae (Diptera) of North and South Carolina. North Carolina Department and Natural Resources, Division of Water Quality, Raleigh, North Carolina.

Friberg, N., B. Kronvang, H. Ole Hansen, and L.M. Svendsen. 1998. Long-term, habitat-specific response of a macroinvertebrate community to river restoration. Aquatic Conservation: Marine and Freshwater Ecosystems 8:87-99.

Grace, M.R., D.P. Giling, S. Hladyz, V. Caron, R.M. Thompson, and R. MacNally. 2015. Fast processing of diel oxygen curves: estimating metabolism with BASE (Bayesian Singlestation Estimation). Limnology and Oceanography: Methods 13:103-114.

Griffiths, N.A., J.L. Tank, T.V. Royer, S.S. Roley, E.J. Rosi-Marshall, M.R. Whiles, J.J. Beaulieu, and L.T. Johnson. 2013. Agricultural land use alters the seasonality and magnitude of stream metabolism. Limnology and Oceanography 58:1513-1529.

Hamilton, S.K. 2012. Biogeochemical time lags may delay responses of streams to ecological restoration. Freshwater Biology 57:43-57.

Hoellein, T.J., J.L. Tank, E.J. Rosi-Marshall, S.A. Entrekin, and G.A. Lamberti. 2007. Controls on spatial and temporal variation of nutrient uptake in three Michigan streams. Limnology and Oceanography 52:1964-1977.

Houser, J.N., P.J. Mulholland, and K. Maloney. 2005. Catchment disturbance and stream metabolism: patterns in ecosystem respiration and gross primary production along a gradient of upland soil and vegetation disturbance. Journal of the North American Benthological Society 24:538-552.

Houser, J.N., P.J. Mulholland, and K.O. Maloney. 2006. Upland disturbance affects headwater stream nutrients and suspended sediments during baseflow and stormflow. Journal of Environmental Quality 35:352-365.

Kummu, M., H. de Moel, P.J. Ward, and O. Varis. 2011. How close do we live to water? A global analysis of population distance to freshwater bodies. PLoS ONE 6:e20578.

Laasonen, P., T. Muotka, and I. Kivijärvi. 1998. Recovery of macroinvertebrate communities from stream habitat restoration. Aquatic Conservation: Marine and Freshwater Ecosystems 8:101-113.

Lake, P.S., N. Bond, and P. Reich. 2007. Linking ecological theory with stream restoration. Freshwater Biology 52:597-615.

Lutz, B.D., P.J. Mulholland, and E.S. Bernhardt. 2012. Long-term data reveal patterns and controls on stream water chemistry in a forested stream: Walker Branch, Tennessee. Ecological Monographs 82:367-387.

Maloney, K.O., P.J. Mulholland, and J.W. Feminella. 2005. The effects of catchment scale military land use on stream physical and organic matter variables in small Southeastern Plains catchments (USA). Environmental Management 35:677-691. 
Maloney, K.O., and J.W. Feminella. 2006. Evaluation of single- and multi-metric benthic macroinvertebrate indicators of catchment disturbance over time at the Fort Benning Military Installation, Georgia, USA. Ecological Indicators 6:469-484.

Maloney, K.O., R.M. Mitchell, and J.W. Feminella. 2006. Influence of catchment disturbance from military training on fish assemblages in small southeastern headwater streams. Southeastern Naturalist 5:393-412.

Maloney, K.O., J.W. Feminella, R.M. Mitchell, S.A. Miller, P.J. Mulholland, and J.N. Houser. 2008. Landuse legacies and small streams: identifying relationships between historical land use and contemporary stream conditions. Journal of the North American Benthological Society 27:280-294.

McManamay, R.A., N.A. Griffiths, C.R. DeRolph, and B.M. Pracheil. 2018. A synopsis of global mapping of freshwater habitats and biodiversity: implications for conservation. Pages 57-87 in L. Hufnagel, editor. Pure and Applied Biogeography. Intech, London, United Kingdom.

Meals, D.W., S.A. Dressing, and T.E. Davenport. 2010. Lag time in water quality response to best management practices: a review. Journal of Environmental Quality 39:85-96.

Merritt, R.W., K.W. Cummins, and M.B. Berg. 2008. An introduction to the aquatic insects of North America. Kendall/Hunt Publishers, Dubuque, Iowa. pp. 862.

Minshall, G.W. 1996. Organic matter budgets. Pages 591-605 in F.R. Hauer and G.A. Lamberti, editors. Methods in stream ecology. Academic Press, San Diego, California.

Mitchell, R.M. 2009. The influence of coarse woody debris, disturbance, and restoration of biological communities in sandy coastal plain streams. PhD dissertation. Auburn University, Auburn, Alabama.

Morse, J.C., W.P. McCafferty, B.P. Stark, and L.M. Jacobus. 2017. Larvae of the southeastern USA: mayfly, stonefly, and caddisfly species (Ephemeroptera, Plecoptera, and Trichoptera). Biota of South Carolina, volume 9. Technical Bulletin 1109, PSA Publishing, Clemson University, Clemson, South Carolina. pp. 482.

Mulholland, P.J., J.N. Houser, and K.O. Maloney. 2005. Stream diurnal dissolved oxygen profiles as indicators of in-stream metabolism and disturbance effects: Fort Benning as a case study. Ecological Indicators 5:243-252.

Mulholland, P.J., J.W. Feminella, B.G. Lockaby, and G.L. Hollon. 2007. Riparian ecosystem management at military installations: determination of impacts and evaluation of restoration and enhancement strategies. Final Technical Report SI-1186. Department of Defense, Strategic Environmental Research and Development Program, Alexandria, Virginia. pp. 161.

Mulholland, P.J., J.W. Feminella, B.G. Lockaby, and G.L. Hollon. 2009. Effects of construction of the Digital Multipurpose Range Complex (DMPRC) on riparian and stream ecosystems at Fort Benning, Georgia. Final Report Addendum. Department of Defense, Strategic Environmental Research and Development Program, Alexandria, Virginia. pp. 81.

Muotka, T., R. Paavola, A. Haapala, M. Novikmec, and P. Laasonen. 2002. Long-term recovery of stream habitat structure and benthic invertebrate communities from in-stream restoration. Biological Conservation 105:243-253. 
National Research Council (NRC). 1992. Restoration of aquatic ecosystems: science, technology, and public policy. The National Academies Press, Washington, DC. https://doi.org/10.17226/1807.

Noss, R. 1989. Longleaf pine and wiregrass: keystone components of an endangered ecosystem. Natural Areas Journal 9:211-213.

Noss, R.F., W.J. Platt, B.A. Sorrie, A.S. Weakley, D.B. Means, J. Costanza, and R.K. Peet. 2015. How global biodiversity hotspots may go unrecognized: lessons from the North American Coastal Plain. Diversity and Distributions 21:236-244.

Omernik, J.M. 1987. Ecoregions of the conterminous United States. Annals of the Association of America Geographers 77:118-125.

Palmer, M.A., E.S. Bernhardt, J.D. Allan, P.S. Lake, G. Alexander, S. Brooks, J. Carr, S. Clayton, C.N. Dahm, J. Follstad Shah, D.L. Galat, S.G. Loss, P. Goodwin, D.D. Hart, B. Hassett, R. Jenkinson, G.M. Kondolf, R. Lave, J.L. Meyer, T.K. O’Donnell, L. Pagano, and E. Sudduth. 2005. Standards for ecologically successful river restoration. Journal of Applied Ecology 42:208-217.

Rabalais, N.N., R.E. Turner, and W.J. Wiseman, Jr. 2002. Hypoxia in the Gulf of Mexico, a.k.a. "The Dead Zone". Annual Review of Ecology and Systematics 33:235-263.

Rinella, D.J., and J.W. Feminella. 2005. Comparison of benthic macroinvertebrates colonizing sand, wood, and artificial substrates in a low-gradient stream. Journal of Freshwater Ecology 20:209-220.

Roberts, B.J., and P.J. Mulholland. 2007. In-stream biotic control on nutrient biogeochemistry in a forested stream, West Fork of Walker Branch. Journal of Geophysical Research 112:G04002.

Roberts, B.J., P.J. Mulholland, and J.N. Houser. 2007a. Effects of upland disturbance and instream restorations on hydrodynamics and ammonium uptake in headwater streams. Journal of the North American Benthological Society 26:120-135.

Roberts, B.J., P.J. Mulholland, and W.R. Hill. 2007b. Multiple scales of temporal variability in ecosystem metabolism rates: results from 2 years of continuous monitoring in a forested headwater stream. Ecosystems 10:588-606.

Roni, P., T. Beechie, R.E. Bilby, F.E. Leonetti, M.M. Pollock, and G.R. Pess. 2002. A review of stream restoration techniques and a hierarchical strategy for prioritizing restoration in Pacific Northwest watersheds. North American Journal of Fisheries Management 22:1-20.

Roni, P., T. Beechie, G. Pess, and K. Hanson. 2015. Wood placement in river restoration: fact, fiction, and future direction. Canadian Journal of Fisheries and Aquatic Sciences 72:466-478.

Roni, P., K. Hanson, and T. Beechie. 2008. Global review of the physical and biological effectiveness of stream habitat rehabilitation techniques. North American Journal of Fisheries Management 28:856-890.

Shirey, P.D., M.A. Brueseke, J.B. Kenny, and G.A. Lamberti. 2016. Long-term fish community response to a reach-scale stream restoration. Ecology and Society 21:11. 
Smock, L.A., G.M. Metzler, and J.E. Gladden. 1989. Role of debris dams in the structure and functioning of low-gradient headwater streams.

Stewart-Oaten, A., W.W. Murdoch, and K.R. Parker. 1986. Environmental-impact assessment: "pseudoreplication" in time. Ecology 67:929-940.

Stream Solute Workshop. 1990. Concepts and methods for assessing solute dynamics in stream ecosystems. Journal of the North American Benthological Society 9:95-119.

Tank, J.L., M.J. Bernot, and E.J. Rosi Marshall. 2006. Nitrogen limitation and uptake. Pages 213-238 in F.R. Hauer and G.A. Lamberti, editors. Methods in stream ecology. $2^{\text {nd }}$ edition. Academic Press, San Diego, California.

Thompson, D.M. 2005. The history of the use and effectiveness of instream structures in the United States. Pages 35-50 in J. Ehlen, W.C. Haneberg, and R.A. Larson, editors. Humans as geologic agents. Geological Society of America Reviews in Engineering Geology, volume 16, Boulder, Colorado.

Tullos, D.D., D.L. Penrose, G.D. Jennings, and W.G. Cope. 2009. Analysis of functional traits in reconfigured channels: implications for the bioassessment and disturbance of river restoration. Journal of the North American Benthological Society 28:80-92.

US Army Infantry Center (USAIC). 2001. Integrated natural resources management plan, Fort Benning Army Installation 2001-2005. Fort Benning Military Installation, Fort Benning, Georgia. pp. 757.

US Environmental Protection Agency (EPA). 2006. Wadeable streams assessment: a collaborative survey of the nation's streams. EPA 841-B-06-002. US EPA, Office of Research and Development, Office of Water, Washington DC.

US Geological Survey (USGS). 2016. The StreamStats program. http://streamstats.usgs.gov. Accessed on June 24, 2018.

Wallace, J.B., and A.C. Benke. 1984. Quantification of wood habitat in subtropical Coastal Plain streams. Canadian Journal of Fisheries and Aquatic Sciences 41:1643-1652.

Walsh, C.J., A.H. Roy, J.W. Feminella, P.D. Cottingham, P.M. Groffman, and R.P. Morgan II. 2005. The urban stream syndrome: current knowledge and search for a cure. Journal of the North American Benthological Society 24:706-723.

Wang, H., M. Hondzo, C. Xu, V. Poole, and A. Spacie. 2003. Dissolved oxygen dynamics of streams draining an urbanized and an agricultural catchment. Ecological Modelling 160:145161.

Wiggins, G.B. 1996. Larvae of the North American caddisfly genera (Trichoptera). 2nd edition. University of Toronto Press, Toronto, Ontario.

Wohl, E., P.L. Angermeier, B. Bledsoe, G.M. Kondolf, L. MacDonnell, D.M. Merritt, M.A. Palmer, N.L. Poff, and D. Tarboton. 2005. River restoration. Water Resources Research 41:W10301.

Yang, L., S. Jin, P. Danielson, C. Homer, L. Gass, S.M. Bender, A. Case, C. Costello, J. Dewitz, J. Fry, M. Funk, B. Granneman, G.C. Liknes, M. Rigge, and G. Xian. 2018. A new generation of the United States National Land Cover Database: requirements, research 
priorities, design, and implementation strategies. ISPRS Journal of Photogrammetry and Remote Sensing 146:108-123. 


\section{APPENDICES}

\section{Supporting Data}

Appendix 1 - Water quality parameters (temperature, specific conductivity, pH, and nitrate-N, ammonium-N, soluble reactive phosphorus-P, dissolved organic carbon, and total suspended solid concentrations) measured on grab samples collected approximately monthly during low flow conditions (when possible) from May 2017 to January 2019 from all 7 study streams.

Water quality samples were analyzed using standard methods (APHA 2005). ND = samples/data were not collected.

\begin{tabular}{|c|c|c|c|c|c|c|c|c|c|c|}
\hline Stream & Treatment & Date & $\begin{array}{l}\text { Water } \\
\text { temp. } \\
\left({ }^{\circ} \mathbf{C}\right)\end{array}$ & $\begin{array}{c}\text { Specific } \\
\text { cond. } \\
(\mu \mathrm{S} / \mathrm{cm})\end{array}$ & pH & $\begin{array}{c}\text { Nitrate } \\
(\mu \mathrm{g} \mathrm{N} / \mathrm{L})\end{array}$ & $\begin{array}{c}\text { Ammonium } \\
(\mu \mathrm{g} N / \mathrm{L})\end{array}$ & $\begin{array}{c}\text { Soluble } \\
\text { reactive } \\
\text { phosphorus } \\
(\mu \mathrm{g} \mathrm{P} / \mathrm{L})\end{array}$ & $\begin{array}{c}\text { Dissolved } \\
\text { organic } \\
\text { carbon } \\
(\mathrm{mg} \mathrm{C} / \mathrm{L}) \\
\end{array}$ & $\begin{array}{c}\text { Total } \\
\text { suspended } \\
\text { solids }(\mathbf{m g} / \mathbf{L})\end{array}$ \\
\hline $\mathrm{HB}$ & unrestored & $05 / 16 / 17$ & 20.7 & 10 & 5.80 & 1.4 & 5.4 & 83.8 & 2.81 & 6.5 \\
\hline $\mathrm{HB}$ & unrestored & $06 / 22 / 17$ & 22.4 & 11 & 4.32 & 0.9 & 7.0 & 63.3 & 3.64 & 9.7 \\
\hline $\mathrm{HB}$ & unrestored & $07 / 24 / 17$ & 24.2 & 8 & 4.39 & 1.0 & 6.7 & 83.8 & 2.19 & 5.0 \\
\hline $\mathrm{HB}$ & unrestored & $08 / 24 / 17$ & 24.1 & 11 & 4.72 & 2.1 & 3.6 & 55.4 & 2.68 & 6.5 \\
\hline HB & unrestored & $09 / 14 / 17$ & 21.1 & 14 & 4.40 & 3.2 & 4.4 & 32.8 & 3.17 & 3.0 \\
\hline $\mathrm{HB}$ & unrestored & $11 / 30 / 17$ & 16.2 & 12 & 5.96 & 1.1 & 5.7 & 45.0 & 2.52 & ND \\
\hline $\mathrm{HB}$ & unrestored & $12 / 19 / 17$ & 14.7 & 13 & 6.44 & 1.1 & 4.8 & 49.9 & 2.88 & 5.5 \\
\hline $\mathrm{HB}$ & unrestored & $01 / 26 / 18$ & 13.4 & 7 & 4.94 & 0.8 & 4.9 & 47.9 & 3.26 & 2.5 \\
\hline $\mathrm{HB}$ & unrestored & $02 / 24 / 18$ & 18.6 & 11 & 3.80 & 2.2 & 21.4 & 48.8 & 3.20 & 4.2 \\
\hline $\mathrm{HB}$ & unrestored & $04 / 21 / 18$ & 17.2 & 8 & 4.39 & 0.1 & 3.0 & 51.5 & 2.33 & 4.6 \\
\hline HB & unrestored & $06 / 15 / 18$ & 22.4 & 11 & 4.52 & 3.7 & 2.3 & 60.9 & 3.03 & 5.3 \\
\hline HB & unrestored & $07 / 23 / 18$ & 22.9 & 10 & 5.92 & 1.7 & 39.5 & 56.6 & 4.33 & 3.4 \\
\hline HB & unrestored & $08 / 27 / 18$ & 23.8 & 10 & 4.95 & 2.3 & 2.9 & 49.8 & 2.46 & 5.6 \\
\hline $\mathrm{HB}$ & unrestored & $09 / 17 / 18$ & 23.9 & 8 & 6.19 & 0.3 & 6.7 & 54.0 & 2.49 & 2.7 \\
\hline $\mathrm{HB}$ & unrestored & $12 / 18 / 19$ & 10.9 & 10 & 6.10 & 0.6 & 1.5 & 51.9 & 2.48 & ND \\
\hline SB4 & unrestored & $05 / 15 / 17$ & 20.2 & 15 & 6.30 & 1.1 & 17.6 & 18.2 & 1.98 & 16.8 \\
\hline SB4 & unrestored & $06 / 20 / 17$ & 22.0 & 17 & 5.42 & 3.5 & 17.3 & 25.7 & 1.94 & 27.5 \\
\hline SB4 & unrestored & $07 / 24 / 17$ & 24.4 & 15 & 5.33 & 1.5 & 13.5 & 36.0 & 2.24 & 7.3 \\
\hline
\end{tabular}




\begin{tabular}{|c|c|c|c|c|c|c|c|c|c|c|}
\hline Stream & Treatment & Date & $\begin{array}{l}\text { Water } \\
\text { temp. } \\
\left({ }^{\circ} \mathrm{C}\right)\end{array}$ & $\begin{array}{c}\text { Specific } \\
\text { cond. } \\
(\mu \mathrm{S} / \mathrm{cm})\end{array}$ & $\mathbf{p H}$ & $\begin{array}{c}\text { Nitrate } \\
(\mu \mathrm{g} \mathrm{N} / \mathrm{L})\end{array}$ & $\begin{array}{c}\text { Ammonium } \\
(\mu \mathrm{g} N / L)\end{array}$ & $\begin{array}{c}\text { Soluble } \\
\text { reactive } \\
\text { phosphorus } \\
(\mu \mathrm{g} P / \mathrm{L})\end{array}$ & $\begin{array}{l}\text { Dissolved } \\
\text { organic } \\
\text { carbon } \\
(\mathrm{mg} \mathrm{C} / \mathrm{L}) \\
\end{array}$ & $\begin{array}{c}\text { Total } \\
\text { suspended } \\
\text { solids }(\mathbf{m g} / \mathbf{L})\end{array}$ \\
\hline SB4 & unrestored & $09 / 14 / 17$ & 21.4 & 20 & 5.22 & 1.6 & 9.4 & 17.3 & 1.76 & 5.5 \\
\hline SB4 & unrestored & $11 / 30 / 17$ & 16.5 & 24 & 6.74 & 0.9 & 4.3 & 4.2 & 2.08 & ND \\
\hline SB4 & unrestored & $12 / 21 / 17$ & 15.1 & 20 & 6.48 & 2.5 & 7.9 & 9.4 & 1.52 & 3.6 \\
\hline SB4 & unrestored & $02 / 05 / 18$ & 11.6 & 15 & 5.35 & 1.2 & 19.2 & 16.1 & 1.43 & 2.8 \\
\hline SB4 & unrestored & $02 / 24 / 18$ & 20.7 & 18 & 3.77 & 1.8 & 27.7 & 9.5 & 1.92 & 6.9 \\
\hline SB4 & unrestored & $04 / 21 / 18$ & 15.9 & 19 & 4.86 & 0.5 & 26.1 & 13.4 & 1.36 & 10.0 \\
\hline SB4 & unrestored & $06 / 13 / 18$ & 21.0 & 20 & 5.82 & 2.7 & 21.1 & 27.3 & 2.31 & 12.0 \\
\hline SB4 & unrestored & $07 / 23 / 18$ & 23.7 & 32 & 6.09 & 4.3 & 32.6 & 23.1 & 10.76 & 7.5 \\
\hline SB4 & unrestored & $09 / 17 / 18$ & 26.1 & 13 & 6.36 & 0.9 & 12.4 & 23.5 & 2.18 & 4.0 \\
\hline SB4 & unrestored & $11 / 04 / 18$ & ND & ND & ND & 1.3 & 13.3 & 6.2 & 1.53 & 4.7 \\
\hline SB4 & unrestored & $01 / 04 / 19$ & 14.7 & 19 & 5.71 & 0.0 & 14.0 & 10.9 & 2.04 & 5.6 \\
\hline $\mathrm{BC}$ & unrestored & $05 / 09 / 17$ & 18.5 & 19 & 4.60 & 1.1 & 6.5 & 0.7 & 4.53 & 6.3 \\
\hline $\mathrm{BC}$ & unrestored & $06 / 09 / 17$ & 20.0 & 20 & ND & 9.8 & 6.4 & 0.8 & 2.11 & 4.0 \\
\hline $\mathrm{BC}$ & unrestored & $07 / 19 / 17$ & 22.5 & 22 & 4.26 & 1.2 & 3.5 & 1.2 & 2.16 & 3.1 \\
\hline $\mathrm{BC}$ & unrestored & $08 / 24 / 17$ & 23.1 & 18 & 4.19 & 2.2 & 5.1 & 2.6 & 1.74 & ND \\
\hline $\mathrm{BC}$ & unrestored & $10 / 01 / 17$ & 24.4 & ND & 4.77 & 1.0 & 7.1 & 2.5 & 4.00 & 1.5 \\
\hline $\mathrm{BC}$ & unrestored & $10 / 23 / 17$ & 20.1 & 28 & 4.31 & 3.2 & 5.4 & 17.7 & 11.47 & 28.7 \\
\hline $\mathrm{BC}$ & unrestored & $11 / 30 / 17$ & 13.7 & 25 & 5.27 & 0.7 & 4.9 & 2.0 & 1.83 & ND \\
\hline $\mathrm{BC}$ & unrestored & $12 / 21 / 17$ & 13.9 & 26 & 5.94 & 1.1 & 4.1 & 1.1 & 2.23 & 1.5 \\
\hline $\mathrm{BC}$ & unrestored & $01 / 19 / 18$ & 13.4 & 21 & 4.94 & 1.8 & 2.1 & 0.0 & 1.98 & 1.0 \\
\hline $\mathrm{BC}$ & unrestored & $02 / 15 / 18$ & 15.2 & 20 & 4.34 & 0.8 & 3.5 & 0.0 & 2.71 & 2.4 \\
\hline $\mathrm{BC}$ & unrestored & $03 / 29 / 18$ & 17.0 & 19 & 4.07 & 0.0 & 5.7 & 0.0 & 1.72 & 1.6 \\
\hline $\mathrm{BC}$ & unrestored & $06 / 15 / 18$ & 21.6 & 19 & 4.23 & 2.8 & 5.5 & 0.1 & 2.55 & 1.9 \\
\hline $\mathrm{BC}$ & unrestored & $07 / 23 / 18$ & 22.1 & 19 & 5.73 & 1.8 & 2.0 & 0.1 & 2.85 & 2.6 \\
\hline $\mathrm{BC}$ & unrestored & $08 / 27 / 18$ & 21.7 & 19 & 5.18 & 3.5 & 16.0 & 0.0 & 1.87 & 4.1 \\
\hline $\mathrm{BC}$ & unrestored & $09 / 28 / 18$ & ND & ND & ND & 3.1 & 8.3 & 0.0 & 2.99 & 6.2 \\
\hline
\end{tabular}




\begin{tabular}{|c|c|c|c|c|c|c|c|c|c|c|}
\hline Stream & Treatment & Date & $\begin{array}{l}\text { Water } \\
\text { temp. } \\
\left({ }^{\circ} \mathrm{C}\right)\end{array}$ & $\begin{array}{l}\text { Specific } \\
\text { cond. } \\
(\mu \mathrm{S} / \mathrm{cm})\end{array}$ & $\mathbf{p H}$ & $\begin{array}{l}\text { Nitrate } \\
(\mu \mathrm{g} \mathrm{N} / \mathrm{L})\end{array}$ & $\begin{array}{c}\text { Ammonium } \\
(\mu \mathrm{g} N / \mathrm{L})\end{array}$ & $\begin{array}{c}\text { Soluble } \\
\text { reactive } \\
\text { phosphorus } \\
(\mu \mathrm{g} \mathrm{P} / \mathrm{L})\end{array}$ & $\begin{array}{l}\text { Dissolved } \\
\text { organic } \\
\text { carbon } \\
(\mathrm{mg} \mathrm{C} / \mathrm{L})\end{array}$ & $\begin{array}{c}\text { Total } \\
\text { suspended } \\
\text { solids }(\mathbf{m g} / \mathbf{L})\end{array}$ \\
\hline $\mathrm{BC}$ & unrestored & $12 / 17 / 19$ & 11.9 & 17 & 6.36 & 0.3 & 1.3 & 0.0 & 2.21 & ND \\
\hline SB3 & restored & $05 / 16 / 17$ & 19.9 & 19 & 6.90 & 1.9 & 5.0 & 16.0 & 2.85 & 26.0 \\
\hline SB3 & restored & $06 / 14 / 17$ & 21.6 & 21 & 5.95 & 2.6 & 9.6 & 18.1 & 2.45 & 15.0 \\
\hline SB3 & restored & $07 / 17 / 17$ & 23.4 & 18 & 5.87 & 2.9 & 8.0 & 19.7 & 3.35 & 10.3 \\
\hline SB3 & restored & 09/14/17 & 21.5 & 22 & 5.57 & 3.5 & 7.2 & 12.3 & 3.59 & 4.4 \\
\hline SB3 & restored & $11 / 30 / 17$ & 16.0 & 24 & 6.81 & 2.7 & 4.2 & 1.7 & 4.05 & ND \\
\hline SB3 & restored & $12 / 22 / 17$ & 15.1 & 25 & 6.88 & 2.3 & 5.7 & 5.5 & 2.38 & 5.4 \\
\hline SB3 & restored & $02 / 05 / 18$ & 12.8 & 21 & 6.01 & 2.4 & 8.0 & 10.8 & 2.04 & 3.5 \\
\hline SB3 & restored & $02 / 24 / 18$ & 19.4 & 24 & 3.94 & 2.1 & 24.0 & 16.4 & 2.42 & 9.7 \\
\hline SB3 & restored & $04 / 21 / 18$ & 14.9 & 21 & 5.08 & 1.1 & 12.4 & 22.1 & 2.82 & 10.3 \\
\hline SB3 & restored & $06 / 14 / 18$ & 23.0 & 21 & 5.34 & 2.1 & 6.9 & 25.0 & 2.86 & 8.5 \\
\hline SB3 & restored & $07 / 22 / 18$ & 22.7 & 21 & 5.23 & 4.8 & 7.8 & 13.4 & 5.50 & 13.3 \\
\hline SB3 & restored & $09 / 17 / 18$ & 25.4 & 20 & 6.30 & 2.0 & 16.0 & 18.9 & 3.04 & 7.7 \\
\hline SB3 & restored & $11 / 04 / 18$ & ND & ND & ND & 2.5 & 13.9 & 0.8 & 2.31 & 5.0 \\
\hline SB3 & restored & $01 / 04 / 19$ & 14.4 & 25 & 5.79 & 1.1 & 9.1 & 2.6 & 3.00 & 17.4 \\
\hline LPK & restored & $05 / 08 / 17$ & 17.3 & 11 & 6.30 & 1.7 & 3.0 & 10.2 & 2.47 & 29.8 \\
\hline LPK & restored & $06 / 21 / 17$ & 21.2 & 11 & 5.00 & 1.8 & 11.7 & 22.4 & 2.95 & 19.7 \\
\hline LPK & restored & 07/19/17 & 22.8 & 14 & 4.20 & 0.6 & 16.0 & 30.5 & 3.35 & 16.3 \\
\hline LPK & restored & $08 / 24 / 17$ & 23.1 & 12 & 4.94 & 5.4 & 14.5 & 27.1 & 2.64 & 13.0 \\
\hline LPK & restored & $10 / 01 / 17$ & 20.4 & 12 & 4.41 & 1.3 & 15.7 & 22.2 & 2.24 & 15.8 \\
\hline LPK & restored & $10 / 23 / 17$ & 20.3 & 12 & 4.49 & 1.4 & 11.2 & 144.8 & 4.72 & 44.3 \\
\hline LPK & restored & $11 / 14 / 17$ & 15.0 & 12 & 5.10 & 2.3 & 5.7 & 10.6 & 1.78 & 5.2 \\
\hline LPK & restored & $01 / 19 / 18$ & 13.4 & 12 & 5.06 & 0.7 & 6.3 & 35.3 & 1.89 & 4.2 \\
\hline LPK & restored & $02 / 15 / 18$ & 16.1 & 14 & 4.18 & 1.1 & 7.9 & 34.0 & 32.01 & 6.7 \\
\hline LPK & restored & $04 / 09 / 18$ & 15.1 & 8 & 5.28 & 0.7 & 5.3 & 19.7 & 2.03 & 6.8 \\
\hline LPK & restored & $04 / 20 / 18$ & 14.8 & 11 & 5.10 & 0.0 & 10.2 & 17.9 & 1.97 & 6.3 \\
\hline
\end{tabular}




\begin{tabular}{|c|c|c|c|c|c|c|c|c|c|c|}
\hline Stream & Treatment & Date & $\begin{array}{l}\text { Water } \\
\text { temp. } \\
\left({ }^{\circ} \mathrm{C}\right)\end{array}$ & $\begin{array}{l}\text { Specific } \\
\text { cond. } \\
(\mu \mathrm{S} / \mathrm{cm})\end{array}$ & $\mathbf{p H}$ & $\begin{array}{l}\text { Nitrate } \\
(\mu g \text { N/L) }\end{array}$ & $\begin{array}{c}\text { Ammonium } \\
(\mu \mathrm{g} \mathrm{N} / \mathrm{L})\end{array}$ & $\begin{array}{c}\text { Soluble } \\
\text { reactive } \\
\text { phosphorus } \\
(\mu \mathrm{g} \mathrm{P} / \mathrm{L})\end{array}$ & $\begin{array}{l}\text { Dissolved } \\
\text { organic } \\
\text { carbon } \\
(\mathrm{mg} \mathrm{C} / \mathrm{L}) \\
\end{array}$ & $\begin{array}{c}\text { Total } \\
\text { suspended } \\
\text { solids }(\mathrm{mg} / \mathrm{L})\end{array}$ \\
\hline LPK & restored & $06 / 21 / 18$ & 22.2 & 11 & 5.30 & 3.2 & 44.1 & 20.8 & 4.76 & 24.1 \\
\hline LPK & restored & $07 / 24 / 18$ & 22.5 & 12 & 6.03 & 0.7 & 53.1 & 20.1 & 3.99 & 14.0 \\
\hline LPK & restored & $08 / 27 / 18$ & 22.7 & 11 & 4.96 & 1.2 & 31.6 & 16.4 & 3.18 & 20.3 \\
\hline LPK & restored & $09 / 28 / 18$ & ND & ND & ND & 1.2 & 32.4 & 9.0 & 2.84 & 18.0 \\
\hline LPK & restored & $11 / 01 / 18$ & ND & ND & ND & 1.9 & 24.7 & 10.9 & 2.05 & 5.6 \\
\hline LPK & restored & $12 / 18 / 19$ & 13.3 & 13 & 6.06 & 0.7 & 10.2 & 18.7 & 2.57 & 0.0 \\
\hline KM1 & restored & $05 / 08 / 17$ & 16.8 & 10 & 4.90 & 3.7 & 8.5 & 29.2 & 4.58 & 31.6 \\
\hline KM1 & restored & $06 / 23 / 17$ & 23.1 & 10 & 4.12 & 1.2 & 6.5 & 11.6 & 4.31 & 8.7 \\
\hline KM1 & restored & $07 / 24 / 17$ & 25.6 & 9 & 4.39 & 1.8 & 4.1 & 14.6 & 3.78 & 5.7 \\
\hline KM1 & restored & 08/29/17 & 22.5 & 10 & 4.13 & 4.0 & 4.0 & 4.3 & 3.19 & 6.5 \\
\hline KM1 & restored & $09 / 14 / 17$ & 19.3 & 14 & 4.15 & 1.2 & 3.2 & 3.3 & 4.01 & 4.3 \\
\hline KM1 & restored & $10 / 23 / 17$ & 20.3 & 23 & 4.18 & 3.5 & 4.9 & 108.5 & 12.17 & 23.3 \\
\hline KM1 & restored & $11 / 13 / 17$ & 14.4 & 12 & 4.55 & 2.0 & 4.2 & 2.0 & 3.97 & 1.8 \\
\hline KM1 & restored & $01 / 29 / 18$ & 12.9 & 10 & 4.86 & 0.8 & 3.1 & 6.2 & 3.50 & 0.8 \\
\hline KM1 & restored & $02 / 15 / 18$ & 16.2 & 11 & 4.06 & 2.0 & 0.0 & 1.9 & 60.89 & 0.7 \\
\hline KM1 & restored & $03 / 29 / 18$ & 17.6 & 9 & 4.34 & 1.6 & 1.5 & 1.2 & 3.03 & 4.8 \\
\hline KM1 & restored & $06 / 18 / 18$ & 21.9 & 12 & 4.33 & 4.8 & 4.6 & 5.5 & 6.13 & 4.5 \\
\hline KM1 & restored & $07 / 24 / 18$ & 22.4 & 11 & 5.96 & 3.6 & 8.2 & 7.4 & 5.36 & 4.8 \\
\hline KM1 & restored & $08 / 27 / 18$ & 22.6 & 9 & 5.12 & 0.8 & 4.7 & 5.5 & 2.48 & 4.3 \\
\hline KM1 & restored & $09 / 28 / 18$ & ND & ND & ND & 1.4 & 10.7 & 0.0 & 4.14 & 4.1 \\
\hline KM1 & restored & $11 / 01 / 18$ & ND & ND & ND & 2.9 & 5.1 & 0.0 & 3.64 & ND \\
\hline KM1 & restored & $12 / 17 / 19$ & 12.6 & 11 & 6.09 & ND & 1.8 & ND & 2.93 & 2.4 \\
\hline SB2 & restored & $05 / 15 / 17$ & 21.4 & 16 & 6.50 & 1.6 & 7.3 & 26.0 & 2.15 & 12.1 \\
\hline SB2 & restored & $06 / 14 / 17$ & 22.9 & 16 & 5.44 & 2.6 & 23.3 & 30.1 & 2.01 & 53.5 \\
\hline SB2 & restored & $07 / 17 / 17$ & 23.8 & 14 & 5.38 & 2.3 & 9.2 & 32.3 & 2.77 & 10.0 \\
\hline SB2 & restored & $09 / 14 / 17$ & 21.4 & 19 & 5.16 & 1.9 & 7.4 & 22.2 & 3.05 & 4.8 \\
\hline
\end{tabular}




\begin{tabular}{|c|c|c|c|c|c|c|c|c|c|c|}
\hline Stream & Treatment & Date & $\begin{array}{l}\text { Water } \\
\text { temp. } \\
\left({ }^{\circ} \mathrm{C}\right)\end{array}$ & $\begin{array}{l}\text { Specific } \\
\text { cond. } \\
(\mu \mathrm{S} / \mathrm{cm})\end{array}$ & pH & $\begin{array}{c}\text { Nitrate } \\
(\mu \mathrm{g} N / L)\end{array}$ & $\begin{array}{c}\text { Ammonium } \\
(\mu \mathrm{g} \mathrm{N} / \mathrm{L})\end{array}$ & $\begin{array}{c}\text { Soluble } \\
\text { reactive } \\
\text { phosphorus } \\
(\mu \mathrm{g} \mathrm{P} / \mathrm{L}) \\
\end{array}$ & $\begin{array}{c}\text { Dissolved } \\
\text { organic } \\
\text { carbon } \\
(\mathrm{mg} \mathrm{C} / \mathrm{L}) \\
\end{array}$ & $\begin{array}{c}\text { Total } \\
\text { suspended } \\
\text { solids }(\mathrm{mg} / \mathrm{L})\end{array}$ \\
\hline SB2 & restored & $11 / 30 / 17$ & 16.4 & 15 & 6.38 & 3.3 & 8.3 & 6.2 & 2.88 & ND \\
\hline SB2 & restored & $12 / 22 / 17$ & 16.2 & 21 & 6.67 & 2.1 & 9.0 & 17.4 & 2.20 & 4.0 \\
\hline SB2 & restored & $02 / 05 / 18$ & 12.7 & 19 & 5.59 & 1.7 & 10.2 & 28.0 & 1.82 & 3.0 \\
\hline SB2 & restored & $02 / 24 / 18$ & 18.2 & 25 & 3.96 & 1.9 & 6.8 & 4.6 & 2.18 & 15.2 \\
\hline SB2 & restored & $04 / 21 / 18$ & 13.4 & 24 & 5.26 & 1.1 & 10.3 & 12.1 & 2.03 & 4.4 \\
\hline SB2 & restored & $06 / 14 / 18$ & 21.0 & 22 & 5.53 & 2.2 & 7.6 & 12.6 & 2.68 & 11.0 \\
\hline SB2 & restored & $07 / 22 / 18$ & 24.1 & 17 & 5.21 & 8.0 & 29.7 & 21.9 & 3.45 & 12.2 \\
\hline SB2 & restored & $09 / 17 / 18$ & 25.1 & 13 & 6.31 & 1.1 & 12.9 & 21.7 & 19.38 & 22.5 \\
\hline SB2 & restored & $11 / 04 / 18$ & ND & ND & ND & 0.5 & 23.1 & 11.0 & 2.12 & 5.0 \\
\hline SB2 & restored & $01 / 04 / 19$ & 14.8 & 25 & 5.75 & 0.6 & 12.0 & 8.1 & 2.51 & 20.8 \\
\hline
\end{tabular}


Appendix 2 - Ammonium uptake rates in the 7 study streams in summer 2017 (June), fall 2017 (November/December), spring 2018 (March/April), summer 2018 (July), and fall 2018 (December/January). Ammonium uptake metrics include uptake length $\left(S_{W} ; \mathrm{m}\right)$, uptake velocity $\left(v_{f} ; \mathrm{mm} / \mathrm{s}\right)$, and areal uptake rate $\left(U ; \mathrm{mg} \mathrm{N} / \mathrm{m}^{2} / \mathrm{d}\right) . \mathrm{NU}^{*}=$ no measurable uptake (i.e., no measurable demand by stream biota for ammonium).

\begin{tabular}{|c|c|c|c|c|c|c|}
\hline Stream & Treatment & Date & Season & $S_{W}(\mathbf{m})$ & $\begin{array}{c}v_{f} \\
(\mathrm{~mm} / \mathrm{s})\end{array}$ & $\begin{array}{c}U \\
\left(\mathrm{mg} \mathrm{N} / \mathrm{m}^{2} / \mathrm{d}\right)\end{array}$ \\
\hline HB & Unrestored & $06 / 22 / 2017$ & Summer & NU* & NU* & NU* \\
\hline SB4 & Unrestored & $06 / 14 / 2017$ & Summer & NU* & NU* & $\mathrm{NU}^{*}$ \\
\hline $\mathrm{BC}$ & Unrestored & 06/09/2017 & Summer & $\mathrm{NU}^{*}$ & NU* & NU* \\
\hline SB3 & Restored & $06 / 14 / 2017$ & Summer & $\mathrm{NU}^{*}$ & $\mathrm{NU}^{*}$ & $\mathrm{NU}^{*}$ \\
\hline LPK & Restored & $06 / 21 / 2017$ & Summer & 103.5 & 0.04 & 95.6 \\
\hline KM1 & Restored & $06 / 23 / 2017$ & Summer & 517.3 & 0.02 & 20.2 \\
\hline SB2 & Restored & $06 / 14 / 2017$ & Summer & NU* & NU* & $\mathrm{NU}^{*}$ \\
\hline $\mathrm{HB}$ & Unrestored & $12 / 19 / 2017$ & Fall & 227.6 & 0.04 & 18.1 \\
\hline SB4 & Unrestored & $12 / 21 / 2017$ & Fall & 401.0 & $<0.01$ & 6.2 \\
\hline $\mathrm{BC}$ & Unrestored & $12 / 21 / 2017$ & Fall & 74.3 & 0.05 & 17.7 \\
\hline SB3 & Restored & $12 / 22 / 2017$ & Fall & 268.8 & 0.01 & 4.2 \\
\hline LPK & Restored & $11 / 14 / 2017$ & Fall & 129.1 & 0.02 & 8.6 \\
\hline KM1 & Restored & $11 / 13 / 2017$ & Fall & NU* & NU* & NU* \\
\hline SB2 & Restored & $12 / 22 / 2017$ & Fall & 78.20 & 0.08 & 62.7 \\
\hline $\mathrm{HB}$ & Unrestored & $04 / 21 / 2018$ & Spring & 225.1 & 0.03 & 10.4 \\
\hline SB4 & Unrestored & $04 / 21 / 2018$ & Spring & 100.3 & 0.05 & 42.2 \\
\hline $\mathrm{BC}$ & Unrestored & $03 / 29 / 2018$ & Spring & 36.7 & 0.10 & 31.4 \\
\hline SB3 & Restored & $04 / 21 / 2018$ & Spring & NU* & NU* & NU* \\
\hline LPK & Restored & $04 / 20 / 2018$ & Spring & 461.3 & $<0.01$ & 3.1 \\
\hline KM1 & Restored & $03 / 29 / 2018$ & Spring & 329.1 & 0.02 & 8.1 \\
\hline SB2 & Restored & $04 / 21 / 2018$ & Spring & 510.0 & $<0.01$ & 7.1 \\
\hline $\mathrm{HB}$ & Unrestored & $07 / 23 / 2018$ & Summer & 164.2 & 0.05 & 46.7 \\
\hline SB4 & Unrestored & $07 / 23 / 2018$ & Summer & $\mathrm{NU}^{*}$ & $\mathrm{NU}^{*}$ & $\mathrm{NU}^{*}$ \\
\hline $\mathrm{BC}$ & Unrestored & $07 / 23 / 2018$ & Summer & 828.3 & $<0.01$ & 3.9 \\
\hline SB3 & Restored & $07 / 22 / 2018$ & Summer & 521.8 & $<0.01$ & 12.2 \\
\hline LPK & Restored & $07 / 24 / 2018$ & Summer & NU* & $\mathrm{NU}^{*}$ & NU* \\
\hline KM1 & Restored & $07 / 24 / 2018$ & Summer & 75.6 & $<0.01$ & 4.2 \\
\hline SB2 & Restored & $07 / 22 / 2018$ & Summer & 60.5 & 0.10 & 226.2 \\
\hline HB & Unrestored & $12 / 18 / 2018$ & Fall & $\mathrm{NU}^{*}$ & NU* & $\mathrm{NU}^{*}$ \\
\hline SB4 & Unrestored & $01 / 04 / 2019$ & Fall & 303.1 & 0.07 & 93.7 \\
\hline $\mathrm{BC}$ & Unrestored & $12 / 17 / 2018$ & Fall & 128.1 & 0.07 & 14.9 \\
\hline SB3 & Restored & 01/04/2019 & Fall & 2916.4 & $<0.01$ & 3.1 \\
\hline
\end{tabular}




\begin{tabular}{llclccc}
\hline \hline Stream & Treatment & Date & Season & $\boldsymbol{S}_{\boldsymbol{W}}(\mathbf{m})$ & $\begin{array}{c}\boldsymbol{v}_{\boldsymbol{f}} \\
(\mathbf{m m} / \mathbf{s})\end{array}$ & $\begin{array}{c}\boldsymbol{U} \\
\left(\mathbf{m g ~ N} / \mathbf{m}^{2} / \mathbf{d}\right)\end{array}$ \\
\hline LPK & Restored & $12 / 18 / 2018$ & Fall & 87.9 & 0.03 & 18.6 \\
KM1 & Restored & $12 / 17 / 2018$ & Fall & NU* & $\mathrm{NU}^{*}$ & $\mathrm{NU}^{*}$ \\
SB2 & Restored & $01 / 04 / 2019$ & Fall & NU* & $\mathrm{NU}^{*}$ & $\mathrm{NU}^{*}$ \\
\hline
\end{tabular}


Appendix 3 - Whole-stream metabolism indicators (maximum daily dissolved oxygen [DO] deficit [an indicator of ecosystem respiration] and the DO deficit daily amplitude [an indicator of gross primary production]), measured in the 7 study streams in summer 2017 (June), fall 2017 (November/December), spring 2018 (March/April), summer 2018 (July), and fall 2018 (December/January). When possible, mean DO metrics were calculated from data collected over multiple days in a given season.

\begin{tabular}{|c|c|c|c|c|c|c|}
\hline Stream & Treatment & Date & Season & Year & $\begin{array}{c}\text { Max daily } \\
\text { DO deficit } \\
(\mathrm{mg} / \mathrm{L})\end{array}$ & $\begin{array}{l}\text { DO deficit daily } \\
\text { amplitude } \\
(\mathrm{mg} / \mathrm{L})\end{array}$ \\
\hline $\mathrm{HB}$ & Unrestored & $06 / 23 / 17$ & Summer & 2017 & 1.23 & 0.36 \\
\hline HB & Unrestored & $06 / 24 / 17$ & Summer & 2017 & 1.08 & 0.22 \\
\hline HB & Unrestored & $06 / 25 / 17$ & Summer & 2017 & 1.10 & 0.36 \\
\hline $\mathrm{HB}$ & Unrestored & $06 / 26 / 17$ & Summer & 2017 & 1.29 & 0.57 \\
\hline HB & Unrestored & $06 / 27 / 17$ & Summer & 2017 & 1.18 & 0.38 \\
\hline $\mathrm{HB}$ & Unrestored & $06 / 28 / 17$ & Summer & 2017 & 1.31 & 0.44 \\
\hline $\mathrm{HB}$ & Unrestored & $06 / 29 / 17$ & Summer & 2017 & 1.26 & 0.29 \\
\hline HB & Unrestored & $06 / 30 / 17$ & Summer & 2017 & 1.29 & 0.25 \\
\hline $\mathrm{HB}$ & Unrestored & $12 / 20 / 17$ & Fall & 2017 & 1.68 & 0.30 \\
\hline $\mathrm{HB}$ & Unrestored & $12 / 21 / 17$ & Fall & 2017 & 1.68 & 0.35 \\
\hline HB & Unrestored & $12 / 22 / 17$ & Fall & 2017 & 1.55 & 0.28 \\
\hline $\mathrm{HB}$ & Unrestored & $04 / 24 / 18$ & Spring & 2018 & 1.53 & 0.19 \\
\hline $\mathrm{HB}$ & Unrestored & $04 / 25 / 18$ & Spring & 2018 & 1.55 & 0.19 \\
\hline HB & Unrestored & $04 / 26 / 18$ & Spring & 2018 & 1.55 & 0.33 \\
\hline $\mathrm{HB}$ & Unrestored & $04 / 27 / 18$ & Spring & 2018 & 1.56 & 0.25 \\
\hline $\mathrm{HB}$ & Unrestored & $04 / 28 / 18$ & Spring & 2018 & 1.63 & 0.31 \\
\hline $\mathrm{HB}$ & Unrestored & $07 / 24 / 18$ & Summer & 2018 & 1.18 & 0.11 \\
\hline $\mathrm{HB}$ & Unrestored & $07 / 25 / 18$ & Summer & 2018 & 1.22 & 0.15 \\
\hline $\mathrm{HB}$ & Unrestored & $07 / 26 / 18$ & Summer & 2018 & 1.21 & 0.11 \\
\hline $\mathrm{HB}$ & Unrestored & $07 / 27 / 18$ & Summer & 2018 & 1.16 & 0.11 \\
\hline $\mathrm{HB}$ & Unrestored & $07 / 28 / 18$ & Summer & 2018 & 1.16 & 0.13 \\
\hline $\mathrm{HB}$ & Unrestored & 07/29/18 & Summer & 2018 & 1.12 & 0.12 \\
\hline HB & Unrestored & $07 / 30 / 18$ & Summer & 2018 & 1.13 & 0.11 \\
\hline $\mathrm{HB}$ & Unrestored & $12 / 18 / 18$ & Fall & 2018 & 1.52 & 0.13 \\
\hline SB4 & Unrestored & $06 / 21 / 17$ & Summer & 2017 & 1.17 & 0.73 \\
\hline SB4 & Unrestored & $06 / 22 / 17$ & Summer & 2017 & 3.21 & 2.18 \\
\hline SB4 & Unrestored & $06 / 23 / 17$ & Summer & 2017 & 2.40 & 1.47 \\
\hline SB4 & Unrestored & $06 / 24 / 17$ & Summer & 2017 & 1.39 & 0.45 \\
\hline SB4 & Unrestored & $06 / 25 / 17$ & Summer & 2017 & 1.39 & 0.49 \\
\hline SB4 & Unrestored & $06 / 26 / 17$ & Summer & 2017 & 1.58 & 0.82 \\
\hline
\end{tabular}




\begin{tabular}{|c|c|c|c|c|c|c|}
\hline Stream & Treatment & Date & Season & Year & $\begin{array}{c}\text { Max daily } \\
\text { DO deficit } \\
(\mathrm{mg} / \mathrm{L})\end{array}$ & $\begin{array}{l}\text { DO deficit daily } \\
\text { amplitude } \\
(\mathrm{mg} / \mathrm{L})\end{array}$ \\
\hline SB4 & Unrestored & $06 / 27 / 17$ & Summer & 2017 & 1.50 & 0.74 \\
\hline SB4 & Unrestored & $06 / 28 / 17$ & Summer & 2017 & 1.84 & 0.92 \\
\hline SB4 & Unrestored & $12 / 22 / 17$ & Fall & 2017 & 1.34 & 0.14 \\
\hline SB4 & Unrestored & $04 / 24 / 18$ & Spring & 2018 & 1.41 & 0.17 \\
\hline SB4 & Unrestored & $04 / 25 / 18$ & Spring & 2018 & 1.37 & 0.10 \\
\hline SB4 & Unrestored & $04 / 26 / 18$ & Spring & 2018 & 1.69 & 0.40 \\
\hline SB4 & Unrestored & $04 / 27 / 18$ & Spring & 2018 & 1.44 & 0.16 \\
\hline SB4 & Unrestored & $04 / 28 / 18$ & Spring & 2018 & 1.41 & 0.17 \\
\hline SB4 & Unrestored & $04 / 29 / 18$ & Spring & 2018 & 1.39 & 0.21 \\
\hline SB4 & Unrestored & $07 / 24 / 18$ & Summer & 2018 & 1.12 & 0.09 \\
\hline SB4 & Unrestored & $07 / 25 / 18$ & Summer & 2018 & 1.13 & 0.08 \\
\hline SB4 & Unrestored & $07 / 26 / 18$ & Summer & 2018 & 1.12 & 0.13 \\
\hline SB4 & Unrestored & $07 / 27 / 18$ & Summer & 2018 & 1.12 & 0.13 \\
\hline SB4 & Unrestored & $07 / 28 / 18$ & Summer & 2018 & 1.23 & 0.29 \\
\hline SB4 & Unrestored & $07 / 29 / 18$ & Summer & 2018 & 1.26 & 0.21 \\
\hline SB4 & Unrestored & $07 / 30 / 18$ & Summer & 2018 & 1.21 & 0.20 \\
\hline SB4 & Unrestored & 01/06/19 & Fall & 2018 & 1.50 & 0.19 \\
\hline SB4 & Unrestored & 01/07/19 & Fall & 2018 & 1.44 & 0.17 \\
\hline SB4 & Unrestored & $01 / 08 / 19$ & Fall & 2018 & 1.43 & 0.15 \\
\hline SB4 & Unrestored & $01 / 09 / 19$ & Fall & 2018 & 1.48 & 0.16 \\
\hline SB4 & Unrestored & $01 / 10 / 19$ & Fall & 2018 & 1.51 & 0.18 \\
\hline SB4 & Unrestored & $01 / 11 / 19$ & Fall & 2018 & 1.52 & 0.23 \\
\hline $\mathrm{BC}$ & Unrestored & $06 / 10 / 17$ & Summer & 2017 & 1.68 & 0.35 \\
\hline $\mathrm{BC}$ & Unrestored & $06 / 11 / 17$ & Summer & 2017 & 1.66 & 0.30 \\
\hline $\mathrm{BC}$ & Unrestored & $06 / 12 / 17$ & Summer & 2017 & 1.60 & 0.25 \\
\hline $\mathrm{BC}$ & Unrestored & $06 / 13 / 17$ & Summer & 2017 & 1.88 & 0.55 \\
\hline $\mathrm{BC}$ & Unrestored & $06 / 14 / 17$ & Summer & 2017 & 2.79 & 0.93 \\
\hline $\mathrm{BC}$ & Unrestored & $06 / 15 / 17$ & Summer & 2017 & 4.15 & 1.76 \\
\hline $\mathrm{BC}$ & Unrestored & $06 / 16 / 17$ & Summer & 2017 & 4.14 & 1.82 \\
\hline $\mathrm{BC}$ & Unrestored & $12 / 23 / 17$ & Fall & 2017 & 1.70 & 0.18 \\
\hline $\mathrm{BC}$ & Unrestored & $12 / 24 / 17$ & Fall & 2017 & 1.74 & 0.23 \\
\hline $\mathrm{BC}$ & Unrestored & $12 / 25 / 17$ & Fall & 2017 & 1.81 & 0.26 \\
\hline $\mathrm{BC}$ & Unrestored & $03 / 31 / 18$ & Spring & 2018 & 1.44 & 0.53 \\
\hline $\mathrm{BC}$ & Unrestored & $04 / 01 / 18$ & Spring & 2018 & 1.46 & 0.60 \\
\hline $\mathrm{BC}$ & Unrestored & $04 / 02 / 18$ & Spring & 2018 & 1.49 & 0.55 \\
\hline
\end{tabular}




\begin{tabular}{|c|c|c|c|c|c|c|}
\hline Stream & Treatment & Date & Season & Year & $\begin{array}{c}\text { Max daily } \\
\text { DO deficit } \\
(\mathrm{mg} / \mathrm{L})\end{array}$ & $\begin{array}{c}\text { DO deficit daily } \\
\text { amplitude } \\
(\mathrm{mg} / \mathrm{L})\end{array}$ \\
\hline $\mathrm{BC}$ & Unrestored & $04 / 03 / 18$ & Spring & 2018 & 1.55 & 0.56 \\
\hline $\mathrm{BC}$ & Unrestored & $04 / 04 / 18$ & Spring & 2018 & 1.54 & 0.40 \\
\hline $\mathrm{BC}$ & Unrestored & $07 / 24 / 18$ & Summer & 2018 & 1.53 & 0.09 \\
\hline $\mathrm{BC}$ & Unrestored & $07 / 25 / 18$ & Summer & 2018 & 1.64 & 0.23 \\
\hline $\mathrm{BC}$ & Unrestored & $07 / 26 / 18$ & Summer & 2018 & 1.77 & 0.42 \\
\hline $\mathrm{BC}$ & Unrestored & $07 / 27 / 18$ & Summer & 2018 & 1.74 & 0.42 \\
\hline $\mathrm{BC}$ & Unrestored & $07 / 28 / 18$ & Summer & 2018 & 1.73 & 0.35 \\
\hline $\mathrm{BC}$ & Unrestored & $07 / 29 / 18$ & Summer & 2018 & 1.57 & 0.29 \\
\hline $\mathrm{BC}$ & Unrestored & $07 / 30 / 18$ & Summer & 2018 & 1.50 & 0.23 \\
\hline $\mathrm{BC}$ & Unrestored & $12 / 18 / 18$ & Fall & 2018 & 1.75 & 0.15 \\
\hline $\mathrm{BC}$ & Unrestored & $12 / 19 / 18$ & Fall & 2018 & 1.74 & 0.10 \\
\hline $\mathrm{BC}$ & Unrestored & $12 / 20 / 18$ & Fall & 2018 & 1.91 & 0.38 \\
\hline SB3 & Restored & $06 / 15 / 17$ & Summer & 2017 & 1.31 & 0.59 \\
\hline SB3 & Restored & $06 / 16 / 17$ & Summer & 2017 & 1.58 & 0.85 \\
\hline SB3 & Restored & $06 / 17 / 17$ & Summer & 2017 & 1.72 & 0.99 \\
\hline SB3 & Restored & $06 / 18 / 17$ & Summer & 2017 & 1.35 & 0.63 \\
\hline SB3 & Restored & $06 / 19 / 17$ & Summer & 2017 & 1.29 & 0.57 \\
\hline SB3 & Restored & $06 / 20 / 17$ & Summer & 2017 & 1.15 & 0.41 \\
\hline SB3 & Restored & $06 / 21 / 17$ & Summer & 2017 & 1.45 & 0.55 \\
\hline SB3 & Restored & $06 / 22 / 17$ & Summer & 2017 & 1.30 & 0.56 \\
\hline SB3 & Restored & $04 / 22 / 18$ & Spring & 2018 & 1.63 & 0.54 \\
\hline SB3 & Restored & $04 / 23 / 18$ & Spring & 2018 & 1.41 & 0.21 \\
\hline SB3 & Restored & $07 / 23 / 18$ & Summer & 2018 & 0.98 & 0.09 \\
\hline SB3 & Restored & $07 / 24 / 18$ & Summer & 2018 & 0.94 & 0.09 \\
\hline SB3 & Restored & $07 / 25 / 18$ & Summer & 2018 & 0.92 & 0.13 \\
\hline SB3 & Restored & $07 / 26 / 18$ & Summer & 2018 & 0.92 & 0.09 \\
\hline SB3 & Restored & $07 / 27 / 18$ & Summer & 2018 & 0.90 & 0.13 \\
\hline SB3 & Restored & $07 / 28 / 18$ & Summer & 2018 & 3.38 & 2.55 \\
\hline SB3 & Restored & $01 / 06 / 19$ & Fall & 2018 & 1.49 & 0.19 \\
\hline SB3 & Restored & $01 / 07 / 19$ & Fall & 2018 & 1.41 & 0.16 \\
\hline SB3 & Restored & $01 / 08 / 19$ & Fall & 2018 & 1.43 & 0.16 \\
\hline SB3 & Restored & 01/09/19 & Fall & 2018 & 1.47 & 0.13 \\
\hline SB3 & Restored & 01/10/19 & Fall & 2018 & 1.48 & 0.16 \\
\hline SB3 & Restored & $01 / 11 / 19$ & Fall & 2018 & 1.68 & 0.33 \\
\hline LPK & Restored & $06 / 22 / 17$ & Summer & 2017 & 1.04 & 0.33 \\
\hline
\end{tabular}




\begin{tabular}{|c|c|c|c|c|c|c|}
\hline Stream & Treatment & Date & Season & Year & $\begin{array}{c}\text { Max daily } \\
\text { DO deficit } \\
(\mathrm{mg} / \mathrm{L})\end{array}$ & $\begin{array}{c}\text { DO deficit daily } \\
\text { amplitude } \\
(\mathrm{mg} / \mathrm{L})\end{array}$ \\
\hline LPK & Restored & $06 / 23 / 17$ & Summer & 2017 & 1.07 & 0.39 \\
\hline LPK & Restored & $06 / 24 / 17$ & Summer & 2017 & 1.00 & 0.30 \\
\hline LPK & Restored & $06 / 25 / 17$ & Summer & 2017 & 1.09 & 0.53 \\
\hline LPK & Restored & $06 / 26 / 17$ & Summer & 2017 & 1.13 & 0.58 \\
\hline LPK & Restored & $06 / 27 / 17$ & Summer & 2017 & 3.36 & 2.81 \\
\hline LPK & Restored & $06 / 28 / 17$ & Summer & 2017 & 1.68 & 0.89 \\
\hline LPK & Restored & $06 / 29 / 17$ & Summer & 2017 & 1.19 & 0.48 \\
\hline LPK & Restored & $04 / 24 / 18$ & Spring & 2018 & 1.30 & 0.09 \\
\hline LPK & Restored & $04 / 25 / 18$ & Spring & 2018 & 1.26 & 0.07 \\
\hline LPK & Restored & $04 / 26 / 18$ & Spring & 2018 & 1.32 & 0.16 \\
\hline LPK & Restored & $04 / 27 / 18$ & Spring & 2018 & 2.18 & 0.94 \\
\hline LPK & Restored & $04 / 28 / 18$ & Spring & 2018 & 1.26 & 0.08 \\
\hline LPK & Restored & $12 / 19 / 18$ & Fall & 2018 & 1.35 & 0.10 \\
\hline LPK & Restored & $12 / 20 / 18$ & Fall & 2018 & 2.58 & 1.30 \\
\hline KM1 & Restored & $06 / 24 / 17$ & Summer & 2017 & 1.40 & 0.21 \\
\hline KM1 & Restored & $06 / 25 / 17$ & Summer & 2017 & 1.33 & 0.24 \\
\hline KM1 & Restored & $06 / 26 / 17$ & Summer & 2017 & 1.36 & 0.35 \\
\hline KM1 & Restored & $06 / 27 / 17$ & Summer & 2017 & 1.30 & 0.28 \\
\hline KM1 & Restored & $06 / 28 / 17$ & Summer & 2017 & 1.35 & 0.35 \\
\hline KM1 & Restored & $06 / 29 / 17$ & Summer & 2017 & 1.36 & 0.24 \\
\hline KM1 & Restored & $06 / 30 / 17$ & Summer & 2017 & 1.42 & 0.14 \\
\hline KM1 & Restored & $07 / 01 / 17$ & Summer & 2017 & 1.54 & 0.26 \\
\hline KM1 & Restored & $11 / 15 / 17$ & Fall & 2017 & 1.65 & 0.37 \\
\hline KM1 & Restored & $11 / 16 / 17$ & Fall & 2017 & 1.69 & 0.49 \\
\hline KM1 & Restored & $11 / 17 / 17$ & Fall & 2017 & 1.59 & 0.34 \\
\hline KM1 & Restored & $03 / 31 / 18$ & Spring & 2018 & 1.64 & 0.38 \\
\hline KM1 & Restored & $04 / 01 / 18$ & Spring & 2018 & 1.67 & 0.43 \\
\hline KM1 & Restored & $04 / 02 / 18$ & Spring & 2018 & 1.69 & 0.37 \\
\hline KM1 & Restored & $04 / 03 / 18$ & Spring & 2018 & 1.83 & 0.44 \\
\hline KM1 & Restored & $04 / 04 / 18$ & Spring & 2018 & 1.78 & 0.26 \\
\hline KM1 & Restored & $04 / 05 / 18$ & Spring & 2018 & 1.70 & 0.49 \\
\hline KM1 & Restored & $04 / 06 / 18$ & Spring & 2018 & 1.69 & 0.41 \\
\hline KM1 & Restored & $07 / 25 / 18$ & Summer & 2018 & 1.30 & 0.13 \\
\hline KM1 & Restored & $07 / 26 / 18$ & Summer & 2018 & 1.33 & 0.13 \\
\hline KM1 & Restored & $07 / 27 / 18$ & Summer & 2018 & 1.32 & 0.19 \\
\hline
\end{tabular}




\begin{tabular}{|c|c|c|c|c|c|c|}
\hline Stream & Treatment & Date & Season & Year & $\begin{array}{c}\text { Max daily } \\
\text { DO deficit } \\
(\mathrm{mg} / \mathrm{L})\end{array}$ & $\begin{array}{c}\text { DO deficit daily } \\
\text { amplitude } \\
(\mathrm{mg} / \mathrm{L})\end{array}$ \\
\hline KM1 & Restored & $07 / 28 / 18$ & Summer & 2018 & 1.31 & 0.15 \\
\hline KM1 & Restored & $07 / 29 / 18$ & Summer & 2018 & 1.31 & 0.21 \\
\hline KM1 & Restored & $12 / 18 / 18$ & Fall & 2018 & 1.40 & 0.18 \\
\hline KM1 & Restored & $12 / 19 / 18$ & Fall & 2018 & 1.38 & 0.14 \\
\hline KM1 & Restored & $12 / 20 / 18$ & Fall & 2018 & 1.94 & 0.58 \\
\hline SB2 & Restored & $06 / 15 / 17$ & Summer & 2017 & 1.40 & 0.61 \\
\hline SB2 & Restored & $06 / 16 / 17$ & Summer & 2017 & 1.58 & 0.79 \\
\hline SB2 & Restored & $06 / 17 / 17$ & Summer & 2017 & 1.79 & 0.76 \\
\hline SB2 & Restored & $06 / 18 / 17$ & Summer & 2017 & 1.59 & 0.51 \\
\hline SB2 & Restored & $06 / 19 / 17$ & Summer & 2017 & 1.55 & 0.44 \\
\hline SB2 & Restored & $06 / 20 / 17$ & Summer & 2017 & 1.42 & 0.27 \\
\hline SB2 & Restored & $06 / 21 / 17$ & Summer & 2017 & 1.41 & 0.38 \\
\hline SB2 & Restored & $06 / 22 / 17$ & Summer & 2017 & 1.65 & 0.63 \\
\hline SB2 & Restored & $12 / 24 / 17$ & Fall & 2017 & 1.45 & 0.14 \\
\hline SB2 & Restored & $12 / 25 / 17$ & Fall & 2017 & 1.39 & 0.29 \\
\hline SB2 & Restored & $12 / 26 / 17$ & Fall & 2017 & 1.26 & 0.29 \\
\hline SB2 & Restored & $12 / 30 / 17$ & Fall & 2017 & 1.45 & 0.33 \\
\hline SB2 & Restored & $04 / 24 / 18$ & Spring & 2018 & 2.25 & 1.02 \\
\hline SB2 & Restored & $04 / 25 / 18$ & Spring & 2018 & 1.31 & 0.11 \\
\hline SB2 & Restored & $04 / 26 / 18$ & Spring & 2018 & 1.57 & 0.39 \\
\hline SB2 & Restored & $04 / 27 / 18$ & Spring & 2018 & 1.33 & 0.16 \\
\hline SB2 & Restored & $04 / 28 / 18$ & Spring & 2018 & 1.31 & 0.15 \\
\hline SB2 & Restored & $04 / 29 / 18$ & Spring & 2018 & 1.30 & 0.20 \\
\hline SB2 & Restored & $07 / 23 / 18$ & Summer & 2018 & 1.20 & 0.14 \\
\hline SB2 & Restored & $07 / 24 / 18$ & Summer & 2018 & 1.24 & 0.15 \\
\hline SB2 & Restored & $07 / 25 / 18$ & Summer & 2018 & 1.22 & 0.12 \\
\hline SB2 & Restored & $07 / 26 / 18$ & Summer & 2018 & 1.17 & 0.16 \\
\hline SB2 & Restored & $07 / 27 / 18$ & Summer & 2018 & 1.21 & 0.15 \\
\hline SB2 & Restored & $07 / 28 / 18$ & Summer & 2018 & 1.25 & 0.13 \\
\hline SB2 & Restored & $07 / 29 / 18$ & Summer & 2018 & 1.21 & 0.20 \\
\hline SB2 & Restored & $07 / 30 / 18$ & Summer & 2018 & 1.13 & 0.11 \\
\hline SB2 & Restored & $01 / 05 / 19$ & Fall & 2018 & 1.59 & 0.99 \\
\hline
\end{tabular}


Appendix 4 - Taxonomic list of all benthic macroinvertebrates encountered during HesterDendy sampling in all 7 study streams during the 14-y post-restoration period (2017-2018).

\begin{tabular}{|c|c|}
\hline Annelida & Insecta \\
\hline Clitellata & Diptera \\
\hline Haplotaxida & Chironomidae (Chironominae) \\
\hline Enchytraidae & Chironomidae (Tanytarsini) \\
\hline Lumbricidae & Chironomidae (Orthocladiinae) \\
\hline Naididae & $\begin{array}{l}\text { Chironomidae } \\
\text { (Tanypodinae) }\end{array}$ \\
\hline Lumbriculida & Empididae \\
\hline Lumbriculidae & Clinocera \\
\hline Arthropoda & Hemerodromia \\
\hline Entognatha & Ptychopteridae \\
\hline Collembola & Bittacomorpha \\
\hline Poduridae & Simuliidae \\
\hline Podura & Simulium \\
\hline Isotomidae & Stratiomyidae \\
\hline Hexanauplia & Tipulidae \\
\hline Cyclopoida & Antocha \\
\hline Harpacticoida & Dicranota \\
\hline Insecta & Hexatoma \\
\hline Coleoptera & Leptotarsus \\
\hline Carabidae & Limnophila \\
\hline Dytiscidae & Limonia \\
\hline Hydrocolus & Ormosia \\
\hline Elmidae & Prionocera \\
\hline Anchytarsus & Pseudolimnephila \\
\hline Ancyronyx & Tipula \\
\hline Dubiraphia & Ephemeroptera \\
\hline Stenelmis & Baetidae \\
\hline Gyrinidae & Baetis \\
\hline Dineutus & Procloeon \\
\hline Hydraenidae & Beraeidae \\
\hline Hydraena & Beraea \\
\hline Diptera & Ephemerellidae \\
\hline Ceratopogonidae & Eurylophella \\
\hline Alluaudomyia & Ephemeridae \\
\hline Bezzia & Hexagenia \\
\hline
\end{tabular}




\begin{tabular}{|c|c|}
\hline Annelida & Insecta \\
\hline Ceratopogon & Heptageniidae \\
\hline Culicoides & Maccaffertium \\
\hline Dasyhelea & Stenacron \\
\hline Forcipomyia & Stenonema \\
\hline Mallochohelea & Isonychiidae \\
\hline Monohelea & Isonychia \\
\hline Probezzia & Leptophlebiidae \\
\hline Stilobezzia & Leptophlebia \\
\hline & Paraleptophlebia \\
\hline & Siphlonuridae \\
\hline & Siphlonurus \\
\hline Insecta & Insecta \\
\hline Hemiptera & Trichoptera \\
\hline Gerridae & Hydropsychidae \\
\hline Rheumatobates & Cheumatopsyche \\
\hline Mesoveliidae & Diplectrona \\
\hline Mesovelia & Hydropsyche \\
\hline Saldidae & Hydroptilidae \\
\hline Veliidae & Anisocentropus \\
\hline Microvelia & Leptoceridae \\
\hline Rhagovelia & Oecetis \\
\hline Lepidoptera & Odontoceridae \\
\hline Megaloptera & Psilotreta \\
\hline Corydalidae & Polycentopodidae \\
\hline Corydalus & Cyrnellus \\
\hline Nigronia & Neureclipsis \\
\hline Sialidae & Nyctiophylax \\
\hline Sialis & Polycentropus \\
\hline Odonata & Psychomiidae \\
\hline Calopterygidae & Lype \\
\hline Hetaerina & Malacostraca \\
\hline Cordulegastridae & Amphipoda \\
\hline Cordulegaster & Gammaridae \\
\hline Gomphidae & Gammarus \\
\hline Dromogomphus & Decapoda \\
\hline Gomphus & Cambaridae \\
\hline Progomphus & Procambarus \\
\hline
\end{tabular}




\begin{tabular}{|c|c|c|}
\hline Annelida & & Insecta \\
\hline & Stylurus & Isopoda \\
\hline & Plecoptera & Asselidae \\
\hline & Capniidae & Asellus \\
\hline & Allocapnia & Ostracoda \\
\hline & Leuctridae & Mollusca \\
\hline & Leuctra & Bivalvia \\
\hline & Perlidae & Sphaeriida \\
\hline & Acroneuria & Sphaeraidae \\
\hline & Eccoptura & \\
\hline & Hansonoperla & \\
\hline & Haploperla & \\
\hline & Perlinella & \\
\hline & Perlodidae & \\
\hline & Diploperla & \\
\hline & Isoperla & \\
\hline & Trichoptera & \\
\hline & Brachycentridae & \\
\hline & Brachycentrus & \\
\hline & Calamoceratidae & \\
\hline & Heteroplectron & \\
\hline
\end{tabular}




\section{List of Scientific/Technical Publications}

\section{Appendix 5 - Conference Abstract Citations}

Bickley, S., D. Isenberg, N.A. Griffiths, B. Helms, and J. Feminella. Lack of long-term effect of coarse woody debris dam restoration on ecosystem functioning and water quality in Coastal Plain streams. Society for Freshwater Science conference, Salt Lake City, UT, May 2019. Oral presentation.

Isenberg, D., S. Bickley, J. Feminella, N.A. Griffiths, and B. Helms. What are the long-term effects of habitat augmentation on biotic composition of streams draining longleaf pine forests? Society for Freshwater Science conference, Salt Lake City, UT, May 2019. Oral presentation.

Isenberg, D., S. Bickley, J. Feminella, N.A. Griffiths, and B. Helms. Long-term effects of instream restoration on biotic assemblages in sandy bottom streams in Fort Benning Military Installation, GA. Association of Southeastern Biologists annual meeting, Memphis, TN, April 2019. Oral presentation.

Davis, E., M. Schimmer, D. Isenberg, and B. Helms. A comparison of clearwater and blackwater streams in Fort Benning Military Installation, GA, using abiotic and biotic parameters. Association of Southeastern Biologists annual meeting, Memphis, TN, April 2019. Poster presentation.

Conklin, L., A. Rogers, D. Isenberg, and B. Helms. Long-term carbon retention of restored sandy-bottom streams at Fort Benning Military Installation. Association of Southeastern Biologists annual meeting, Memphis, TN, April 2019. Poster presentation.

Griffiths, N.A., S. Bickley, D.J. Isenberg, B.S. Helms, and J.W. Feminella. Evaluating long-term stream ecosystem responses to restoration at Fort Benning Military Installation in Georgia. SERDP-ESTCP Symposium, Washington DC, November 2018. Poster presentation.

Bickley, S., D. Isenberg, N.A. Griffiths, B. Helms, and J. Feminella. The long-term effect of stream restoration on water-quality, nutrient uptake, and whole-stream metabolism in sandybottom, coastal plain streams. Alabama Water Resources Conference, Orange Beach, AL, September 2018. Oral presentation.

Isenberg, D., S. Bickley, J. Feminella, N.A. Griffiths, and B. Helms. Long-term effects of instream restoration on macroinvertebrates in sandy bottom streams at Fort Benning Military Installation, GA. Ecological Society of America conference, New Orleans, LA, August 2018. Poster presentation.

Bickley, S., D. Isenberg, N.A. Griffiths, B. Helms, and J.W. Feminella. Long-term stream restoration effects on ecosystem functions in Coastal Plain streams. Society for Freshwater Science conference, Detroit, MI, May 2018. Oral presentation.

Isenberg, D., S. Bickley, J. Feminella, N.A. Griffiths, and B. Helms. Long-term effects of instream restoration on macroinvertebrates in sandy bottom streams at Fort Benning Military Installation, GA. Society for Freshwater Science conference, Detroit, MI, May 2018. Poster presentation. 